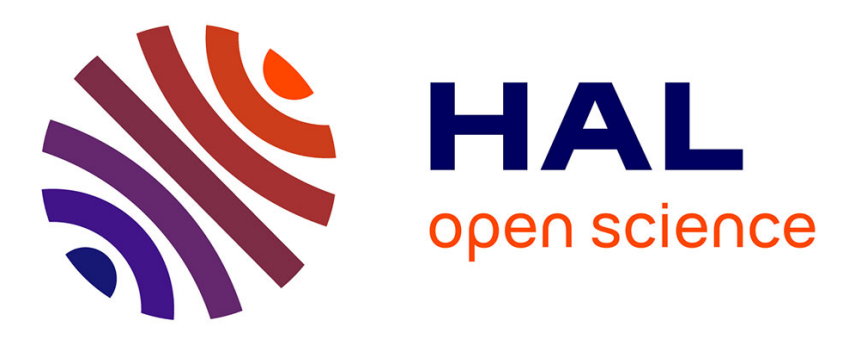

\title{
The state of BEA zeolite supported nickel catalysts in CO2 methanation reaction
}

\author{
Wojciech Gac, Witold Zawadzki, Grzegorz Slowik, Marcin Kuśmierz, \\ Stanislaw Dzwigaj
}

\section{- To cite this version:}

Wojciech Gac, Witold Zawadzki, Grzegorz Slowik, Marcin Kuśmierz, Stanislaw Dzwigaj. The state of BEA zeolite supported nickel catalysts in CO2 methanation reaction. Applied Surface Science, 2021, 564, pp.150421. 10.1016/j.apsusc.2021.150421 . hal-03360250

\section{HAL Id: hal-03360250 \\ https://hal.sorbonne-universite.fr/hal-03360250}

Submitted on 30 Sep 2021

HAL is a multi-disciplinary open access archive for the deposit and dissemination of scientific research documents, whether they are published or not. The documents may come from teaching and research institutions in France or abroad, or from public or private research centers.
L'archive ouverte pluridisciplinaire HAL, est destinée au dépôt et à la diffusion de documents scientifiques de niveau recherche, publiés ou non, émanant des établissements d'enseignement et de recherche français ou étrangers, des laboratoires publics ou privés. 


\section{Effects of dealumination on the performance of Ni-containing BEA catalysts in bioethanol steam reforming}

Wojciech Gac ${ }^{1, *}$, Magdalena Greluk ${ }^{1}$, Grzegorz Słowik ${ }^{1}$, Yannick Millot ${ }^{2}$, Laetitia Valentin ${ }^{2}$, Stanislaw Dzwigaj ${ }^{2 *}$

${ }^{1}$ Department of Chemical Technology, Faculty of Chemistry, Maria Curie-Sklodowska

University, 3 M. Curie-Sklodowska Sq., 20-031 Lublin, Poland

${ }^{2}$ Laboratoire de Réactivité de Surface, Sorbonne Université-CNRS, UMR 7197, F-75005, Paris, France

Tables: 3

Figures: 15

Keywords: Nickel, beta zeolites, bioethanol, stream reforming

*Corresponding authors:

${ }^{1}$ Wojciech Gac, E-mail: wojciech.gac@umcs.lublin.pl, tel. +48 815377746

${ }^{2}$ Stanislaw Dzwigaj, E-mail: stanislaw.dzwigaj@upmc.fr, tel: +33 144272113 


\section{Abstract}

The effects of dealumination of BEA zeolite on the formation of nickel active sites and the performance of Ni-containing BEA zeolite catalysts in the steam reforming of ethanol have been studied. Ni-containing BEA zeolite catalysts were prepared by the impregnation of unmodified and dealuminated BEA zeolites with $\mathrm{Ni}\left(\mathrm{NO}_{3}\right)_{2}$ precursor. The properties of $\mathrm{Ni}_{10} \mathrm{HAlBEA}$ and $\mathrm{Ni}_{10} \mathrm{SiBEA}$ zeolite catalysts were studied by means of $\mathrm{X}$-ray diffraction, ${ }^{1} \mathrm{H}$, ${ }^{27} \mathrm{Al}$ and ${ }^{29} \mathrm{Si}$ magic-angle spinning nuclear magnetic resonance, Fourier-transform infrared and Raman spectroscopy, transmission electron microscopy, temperature-programmed reduction, temperature-programmed ammonia and hydrogen desorption methods. High initial activity and selectivity of $\mathrm{Ni}_{10} \mathrm{HAlBEA}$ to hydrogen and carbon dioxide with unmodified BEA zeolite support in the steam reforming of ethanol reaction performed at $500{ }^{\circ} \mathrm{C}$ was observed. However, fast deactivation of $\mathrm{Ni}_{10} \mathrm{HAlBEA}$ catalyst, manifested in the decrease of water conversion, drop of selectivity to $\mathrm{H}_{2}$ and $\mathrm{CO}_{2}$, and increase in the selectivity to ethylene with the time-on-stream, was observed. In contrast, $\mathrm{Ni}_{10} \mathrm{SiBEA}$ zeolite catalyst showed lower initial activity but higher durability and resistance for carbon deposition. It was stated that dealumination of BEA zeolite led to the slight structural changes and simultaneously pronounced decrease of acidity. Formation of the large nickel crystallites was hindered on $\mathrm{Ni}_{10} \mathrm{SiBEA}$ zeolite catalyst. TEM and Raman spectroscopy studies indicated that deactivation of $\mathrm{Ni}_{10} \mathrm{HAlBEA}$ was related with to formation of nickel mediated filamentous, graphitic and amorphous carbon deposits. Much smaller amounts of filamentous carbons were observed on the $\mathrm{Ni}_{10} \mathrm{SiBEA}$ zeolite catalyst prepared by the use of dealuminated zeolite support. 


\section{Introduction}

Bioethanol has been commonly used as solvent, valuable chemical and energy carrier. It is currently produced mainly from sugar and starch crops, however, it seems that bioethanol can be also commercially synthesized in the near future from wood residues, wastes or energy crops [1-4]. This may increase the potential applications of bioethanol for production of biofuels, biopolymers, and energy carriers, such as hydrogen which can be subsequently utilised for generation of electricity in the fuel cell systems. Ethanol, as a liquid fuel can be easily transported and stored, therefore directly used as hydrogen carrier for stationary and mobile units. One of the most attractive ways of the production of hydrogen from renewable sources is steam reforming of ethanol (ESR): $\mathrm{C}_{2} \mathrm{H}_{5} \mathrm{OH}+3 \mathrm{H}_{2} \mathrm{O} \rightarrow 6 \mathrm{H}_{2}+2 \mathrm{CO}_{2}, \Delta H_{298 K}^{0}=$ $173.2 \mathrm{~kJ} \mathrm{~mol}^{-1}$. Reaction can be carried out in the presence of supported noble and transition metal catalysts, including rhodium, nickel and cobalt in the range of $300-500{ }^{\circ} \mathrm{C}$ [5-11]. Bio$\mathrm{CO}_{2}$ - the product of the steam reforming of bioethanol can be easily removed from the product stream or even supplied together with hydrogen to the fuel cells. Depending on the properties of catalysts and reaction conditions, additional side products of ESR are often observed in the product stream, including carbon monoxide, acetaldehyde, acetone, acetic acid, methane, ethane, ethylene and higher hydrocarbons [5-10]. The catalysts may deactivate with the time-on-stream due to the sintering and formation of carbon deposits. Several routes have been proposed to improve the activity and durability of catalysts. Large-surface area supports, such as $\gamma-\mathrm{Al}_{2} \mathrm{O}_{3}$, silica mesoporous materials, mixed oxides, e.g. $\mathrm{Ce}_{\mathrm{x}} \mathrm{Zr}_{1-\mathrm{x}} \mathrm{O}_{2}$, usually allow for the formation of strongly dispersed surface precursors and retard sintering processes. Similar effect can be achieved by the introduction of certain modifiers or promoters, which change metal-support interactions. However, large number of acid or redox sites presented on the surface of supports may intensify dehydration reaction with formation of ethylene or condensation/ketonization reactions, leading to the production of acetone and 
acetic acid. Ethylene is commonly regarded as coke precursor. Acetone can be also transformed to coke through mesityl oxide formation and further aldol condensation [12-15]. On the other hand, an introduction of redox components into the catalysts or modification of the acidity by some means, may improve coking resistance. It is commonly accepted opinion that ethanol molecules in the steam reforming reaction are dissociatively adsorbed on the surface of catalysts with formation of ethoxy groups. Such species can be subsequently transformed into various intermediates by successive dehydrogenation and dehydration reactions, $\mathrm{C}-\mathrm{C}$ bond scission, oxidative surface reactions with contribution of hydroxyl groups or oxygen species in the catalysts. The intensification of surface reactions between carbonaceous surface intermediates - coke precursors with surface oxygen species or hydroxyl groups, bounded to the acid sites may retard fast development of filamentous or encapsulating deposits.

In spite of vast literature devoted to the ESR reaction in the last years, zeolite supported catalysts have not been widely studied. The micro-mesoporous structure of zeolites may promote formation of the small metal nanoparticles [16-21]. On the other hand, high acidity of zeolites may drive to the extensive formation of carbon deposits in the ESR reaction. Several methods of changing acid-base properties of zeolite supports have been proposed, mainly by the introduction of alkali metals or alkali treatment $[17,22,23]$. Dealumination of zeolites has been described in the literature as the useful method of modification of structural, as well as acid-base properties [23-28]. The advantage of the use of dealuminated ITQ-2 zeolites as supports of nickel and cobalt catalysts for the ESR reaction has been recently pointed out by Chica at al. [27,28].

The removal of aluminium ions from the zeolite framework may not only drive to the changes of acidity, but also facilitate formation of peculiar adsorptive sites for anchoring metal precursors and stabilization of metallic nanoparticles. The aim of our studies was 
determination of the effects caused by the dealumination of BEA zeolite supports on the nickel dispersion, structural and surface properties of catalysts, catalytic performance in the steam reforming of ethanol and the nature of carbon deposits.

\section{Experimental}

\subsection{Catalysts preparation}

$\mathrm{Ni}_{10} \mathrm{HAlBEA}$ and $\mathrm{Ni}_{10} \mathrm{SiBEA}$ zeolite catalysts were prepared by conventional wet impregnation and a two-steps postsynthesis procedure, respectively, as reported earlier [30]. A tetraethylammonium BEA (TEABEA) zeolite provided by RIPP (China) was divided for two parts. The first fraction was calcined in air at $550{ }^{\circ} \mathrm{C}$ for $15 \mathrm{~h}$ in order to obtain an organic - free HAlBEA zeolite $(\mathrm{Si} / \mathrm{Al}=17)$. The $\mathrm{Ni}_{10} \mathrm{HAlBEA}$ zeolite catalyst was prepared by impregnation of HAlBEA with an aqueous solution of $\mathrm{Ni}\left(\mathrm{NO}_{3}\right)_{2} \cdot 6 \mathrm{H}_{2} \mathrm{O}(\mathrm{pH}=2.6)$ under aerobic conditions, as described earlier [30]. Then the suspension was stirred for $2 \mathrm{~h}$ at $80{ }^{\circ} \mathrm{C}$ until water evaporation. The resulting solid was dried in air at $80{ }^{\circ} \mathrm{C}$ for $24 \mathrm{~h}$ and then calcined in air at $400{ }^{\circ} \mathrm{C}$ for $2 \mathrm{~h}$.

The second fraction of TEAIBEA was treated in a $13 \mathrm{~mol} \cdot \mathrm{dm}^{-3} \mathrm{HNO}_{3}$ aqueous solution at $80{ }^{\circ} \mathrm{C}$ for $4 \mathrm{~h}$ to obtain a dealuminated and organic - free SiBEA support $(\mathrm{Si} / \mathrm{Al}=1000)$ with vacant $\mathrm{T}$-atom sites $(\mathrm{T}=\mathrm{Al})$. SiBEA was then recovered by centrifugation, washed with distilled water and dried at $80{ }^{\circ} \mathrm{C}$. To incorporate nickel ions in vacant $\mathrm{T}$-atom sites, $2 \mathrm{~g}$ of SiBEA was stirred under aerobic conditions for $24 \mathrm{~h}$ at $25{ }^{\circ} \mathrm{C}$ in $200 \mathrm{~mL}$ of Ni(NO$)_{2} \cdot 6 \mathrm{H}_{2} \mathrm{O}$ aqueous solution $(\mathrm{pH}=2.6)$. The resulting solid was dried in air at $80{ }^{\circ} \mathrm{C}$ for $24 \mathrm{~h}$. Then solid was calcined in air at $400{ }^{\circ} \mathrm{C}$ for $2 \mathrm{~h}$ and labelled as $\mathrm{Ni}_{10} \mathrm{SiBEA}$.

\subsection{Materials characterization}


X-ray diffraction studies (XRD) of materials after calcination and after reduction (prior to the ESR reaction) were performed with Empyrean (PANalytical) diffractometer using $\mathrm{Cu}-\mathrm{K}_{\alpha}$ radiation $(\lambda=1.5418 \AA)$. Rietveld method was used to estimate mean crystallite size of nickel oxide $\left(d_{N i O}\right)$ and metallic nickel $\left(d_{N i}^{X R D}\right)$. The samples prior to the determination of $d_{N i}^{X R D}$ were reduced in the microreactor in the flow of hydrogen with the ramp rate of $10{ }^{\circ} \mathrm{C} \mathrm{min}^{-1}$ up to $600{ }^{\circ} \mathrm{C}$ followed by the isothermal reduction for $2 \mathrm{~h}$. After cooling down to the room temperature, the samples were passivated in the flow of the mixture of $5 \% \mathrm{O}_{2}$ in $\mathrm{He}$.

Nickel content in the catalysts was determined by the application of X-ray fluorescence method using ED-XRF Canberra Packard 1510 spectrometer.

The porous structure and specific surface area of zeolites and modified with nickel after calcination at $400{ }^{\circ} \mathrm{C}$ were determined from the measurements of nitrogen adsorption/desorption isotherms. The isotherms were obtained volumetrically at $-196{ }^{\circ} \mathrm{C}$ using ASAP $2405 \mathrm{~N}$ analyzer (Micromeritics Instrument Corp.). The samples were outgassed under $\sim 10^{-2} \mathrm{~Pa}$ at $200{ }^{\circ} \mathrm{C}$. The standard Brunauer-Emmett-Teller (BET) method was used to calculate specific surface area $\left(S_{B E T}\right)$. The total pore volume $\left(V_{p}\right)$ was estimated from single point adsorption at $p / p_{0}=0.98$. Mean pore dimeter $\left(D_{B J H}\right)$ and pore size distribution were determined by applying the Barret-Joyner-Halenda $(\mathrm{BJH})$ method from the desorption branch of isotherms [31,32].

${ }^{29} \mathrm{Si}$ MAS NMR spectra were recorded at $99.3 \mathrm{MHz}$ with Bruker AVANCE500 spectrometer at $11.7 \mathrm{~T}$ and $7 \mathrm{~mm}$ (external diameter) zirconia rotors. Chemical shifts of silicon were measured by reference to tetramethylsilane (TMS). ${ }^{29} \mathrm{Si}$ MAS NMR spectra were obtained with $5 \mathrm{kHz}$ rotors spinning speed, $3 \mu$ s excitation pulse duration and $10 \mathrm{~s}$ recycle delay. ${ }^{27} \mathrm{Al}$ and ${ }^{1} \mathrm{H}$ MAS NMR experiments were performed on a Bruker AVANCE500 spectrometer at $11.7 \mathrm{~T}$ in $4 \mathrm{~mm}$ zirconia rotors spinning at $12 \mathrm{kHz}$. The resonance frequency of ${ }^{1} \mathrm{H}$ and ${ }^{27} \mathrm{Al}$ were $500.16 \mathrm{MHz}$ and $130.33 \mathrm{MHz}$, respectively. Chemical shifts, $\delta$, were 
reported relative to TMS and aqueous $\mathrm{Al}\left(\mathrm{NO}_{3}\right)_{3} 1 \mathrm{~N}$ solution. ${ }^{1} \mathrm{H}$ MAS NMR spectra are performed with a $90^{\circ}$ pulse duration of $2.6 \mu \mathrm{s}$ and a recycle delay of $5 \mathrm{~s}$ and 16 accumulations. ${ }^{27} \mathrm{Al}$ MAS NMR spectra were recorded by small-flip-angle technique with a pulse of $0.9 \mu \mathrm{s}(\pi / 8), 0.5 \mathrm{~s}$ for the recycle delay and 2048 accumulations.

The FT-IR/PAS spectra were recorded by means of a Nicolet 8700 (Thermo Scientific) spectrometer equipped with PA301 Gasera photoacoustic detector in the range of 400-4000 $\mathrm{cm}^{-1}$ with the resolution of $1 \mathrm{~cm}^{-1}$ and maximum source aperture. A standard carbon black was used as background. A sample was placed to the holder and inserted into the analyzer purged with helium. Interferograms of 1024 scans were averaged for each spectrum.

Acidity of the supports and catalysts was determined by the temperature-programmed desorption of ammonia using Altamira AMI-1 system coupled with mass spectrometer HAL 201RC (Hiden Analytical). The intensities of selected ions were monitored. Samples (0.1 g) were introduced into the plug flow microreactor and were reduced at $600{ }^{\circ} \mathrm{C}$ for $2 \mathrm{~h}$. Samples after cooling down were flushed with helium at $100{ }^{\circ} \mathrm{C}$ for $0.5 \mathrm{~h}$, next flushed with the mixture of $0.5 \% \mathrm{NH}_{3}$ in $\mathrm{He}$ for $0.5 \mathrm{~h}$, and again with $\mathrm{He}$ for $0.5 \mathrm{~h}$. The flow rate of gases was equal to $30 \mathrm{~mL} \min ^{-1}$. Next the temperature was increased with the ramp rate $10{ }^{\circ} \mathrm{C} \mathrm{min}^{-1}$ to $600{ }^{\circ} \mathrm{C}$.

Additionally the surface properties were investigated by the application of Diffuse Reflectance Infrared Fourier-Transform Spectroscopy (DRIFTS). DRIFTS spectra were recorded using FTIR spectrometer (Nicolet 6700, Thermo Scientific) equipped with $\mathrm{LN}_{2}$ cooled MCT/A detector. Samples were introduced into the Praying Mantis High-Temperature Reaction Chamber (Harrick), which was covered by a dome with $\mathrm{ZnSe}$ windows. The samples were heated up in the flow of $\mathrm{H}_{2}\left(30 \mathrm{~mL} \mathrm{~min}^{-1}\right)$ from 20 to $600{ }^{\circ} \mathrm{C}$ with the ramp rate $10{ }^{\circ} \mathrm{C} \mathrm{min}{ }^{-1}$, and after $2 \mathrm{~h}$ of isothermal heating were cooled down to $100{ }^{\circ} \mathrm{C}$. DRIFTS spectra were collected at selected temperatures with the resolution of $0.48 \mathrm{~cm}^{-1}$ and maximum source 
aperture. Interferograms of 256 scans were averaged for each spectrum. The spectra were corrected by applying the background signal recorded for $\mathrm{KBr}$ powder.

Analysis of the acidic properties of samples was also performed by adsorption of pyridine (Py) followed by infrared spectroscopy. Before analysis, the samples were pressed at $\sim 1$ ton $\mathrm{cm}^{-2}$ into thin wafers of ca. $10 \mathrm{mg} \mathrm{cm}^{-2}$ and placed inside the IR cell. Before Py adsorption/desorption experiments, the wafers were activated by calcination in static conditions at $450{ }^{\circ} \mathrm{C}$ for $3 \mathrm{~h}$ in $\mathrm{O}_{2}\left(1.610^{4} \mathrm{~Pa}\right)$ and then outgassing under secondary vacuum at $300{ }^{\circ} \mathrm{C}\left(10^{-3} \mathrm{~Pa}\right)$ for $1 \mathrm{~h}$. These wafers were contacted at room temperature with gaseous Py (133 Pa) via a separate cell containing liquid Py. The spectra were then recorded following desorption at $150{ }^{\circ} \mathrm{C}$ for $1 \mathrm{~h}$ with a Bruker Vector 22 spectrometer (resolution $2 \mathrm{~cm}^{-1}, 128$ scans). The reported spectra were obtained after subtraction of the spectrum recorded before Py adsorption. The amount of Brønsted and Lewis acidic centers titrated by pyridine was

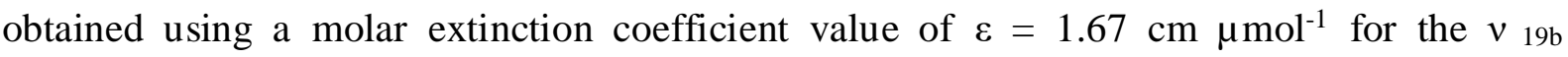
vibrations of protonated pyridine $\left(\mathrm{Py}-\mathrm{H}^{+}\right)$at $\sim 1540 \mathrm{~cm}^{-1}$ and of $\varepsilon=2.22 \mathrm{~cm}^{2} \mathrm{~mol}^{-1}$ for the $v_{19 b}$ vibrations of coordinated pyridine $(\mathrm{Py}-\mathrm{L})$ at $\sim 1455 \mathrm{~cm}^{-1}[33]$.

The FT-IR/PAS spectra were recorded by means of a Nicolet 8700 (Thermo Scientific) spectrometer equipped with PA301 Gasera photoacoustic detector in the range of 400-4000 $\mathrm{cm}^{-1}$ with the resolution of $1 \mathrm{~cm}^{-1}$ and maximum source aperture. A standard carbon black was used as background. A sample was placed to the holder and inserted into the analyzer purged with helium. Interferograms of 1024 scans were averaged for each spectrum.

The nature of carbon deposits in the samples after ESR reaction tests performed at $500{ }^{\circ} \mathrm{C}$ $\mathrm{h}$ for $22 \mathrm{~h}$ was investigated by Raman spectroscopy. Raman spectra were recorded with the resolution of $2 \mathrm{~cm}^{-1}$ in the Raman microscope (inVia Reflex, Renishaw) with the Raman dispersive system, using a semiconducting laser $785 \mathrm{~nm}$ with $0.5 \mathrm{~mW}$ of power to avoid 
sample overheating. Spectra were deconvoluted with the Lorentzian function (available at the PeakFit SeaSolve software).

The catalysts for microscopic studies were grinded in an agate mortar to a fine powder. The resulting powders were poured with $99.8 \%$ ethanol $(\mathrm{POCH})$ to form a slurry which subsequently were inserted into the ultrasonic homogenizer for $20 \mathrm{~s}$. Then, the slurry containing the catalyst were pipetted and supported on a 200 mesh copper grid covered with lacey formvar and stabilized with carbon (Ted Pella Company) and left on the filter paper until the ethanol has evaporated. Subsequently, the samples deposited on the grid were inserted to holder and moved to electron microscope. The electron microscope Tecnai G2 20 X-TWIN FEI Company, equipped with an $\mathrm{LaB}_{6}$ source, HAADF detector and EDS spectrometer (Energy Dispersive X-Ray Spectroscopy) was used to display the prepared catalysts. Microscopic studies of the catalysts were carried out at an accelerating voltage of the electron beam equal to $200 \mathrm{kV}$. The elements mapping was carried out in the STEM mode by collecting point by point EDS spectrum of each of the corresponding pixels in the map. The collected maps were presented in the form of a matrix of pixels with the color mapped significant element and the intensity corresponding to the percentage of the element. The average size of nickel particles $\left(d_{N i}^{T E M}\right)$ was calculated from the equation:

$$
d_{N i}^{T E M}=\frac{\sum n_{i} d_{i}}{\sum n_{i}}
$$

where: $n_{i}$ - the numbers of metal crystallites in a specific size range, $d_{i}$ - the average diameter in each diameter range.

Reducibility of nickel catalysts was investigated by the temperature-programmed reduction method (TPR) using Autochem II 2920 (Micromeritics Instrument Corp.), equipped with thermal conductivity detector (TCD). The samples $(\mathrm{m}=0.05 \mathrm{~g})$ were reduced in the mixture of $5 \% \mathrm{H}_{2}$ in $\mathrm{Ar}$ with the total flow rate of $30 \mathrm{~mL} \mathrm{~min}{ }^{-1}$ using $10{ }^{\circ} \mathrm{C} \mathrm{min}{ }^{-1}$ ramp rate. 
The evolved water was removed from the stream in a cold trap with the mixture of liquid nitrogen and isopropyl alcohol at $-89^{\circ} \mathrm{C}$.

The nature of active surface sites was determined by hydrogen temperatureprogrammed desorption (TPD) method. Studies were carried out in the Autochem II 2920 (Micromeritics Instrument Corp.). The samples $(0.1 \mathrm{~g})$ were initially reduced at $600{ }^{\circ} \mathrm{C}$ for $2 \mathrm{~h}$ and subsequently were cooled down in the flow of hydrogen to $-60^{\circ} \mathrm{C}$. After flushing with $\mathrm{Ar}$ $\left(30 \mathrm{~mL} \mathrm{~min}{ }^{-1}\right)$ and stabilization of TCD signal, the temperature was increased with the ramp rate $10{ }^{\circ} \mathrm{C} \mathrm{min}^{-1}$. The evolved water was removed in a cold trap in a similar manner as in the TPR procedure. The active surface area of nickel catalysts $\left(S_{a}\right)$ was determined by the integration of TPD curves, assuming chemisorption stoichiometry $\mathrm{H}: \mathrm{Ni}=1: 1$ and that the surface area occupied by one atom of hydrogen was equal to $0.0649 \mathrm{~nm}^{2}$.

The activity and selectivity of zeolite supports and nickel-containing zeolite catalysts were determined in the steam reforming of ethanol reaction (ESR) under atmospheric pressure using Microactivity Reference unit (PID Eng \& Tech.), equipped with fixed-bed continuousflow quartz microreactor. The catalyst sample of the weight $0.1 \mathrm{~g}$ was diluted with quartz grains $(0.3-0.6 \mathrm{~mm})$ at the weight ratio of $1 / 25$. The catalysts prior to the reaction were reduced in hydrogen at $600{ }^{\circ} \mathrm{C}$ for $2 \mathrm{~h}$. The aqueous solution of ethanol with molar ratio of water/ethanol $=12 / 1$ was supplied by a mass controller (Bronkhorst) to an evaporator maintained at $150{ }^{\circ} \mathrm{C}$, and the reaction mixture, without diluting with any inert gas, was fed to the reactor at a flow rate of $100 \mathrm{~mL} \mathrm{~min}{ }^{-1}$. Weight hourly space velocity $\left(\mathrm{WHSV}_{\mathrm{EtOH}}\right)$ was equal to $9.5 \mathrm{~g}_{\mathrm{EtOH}} \mathrm{h}^{-1} \mathrm{~g}_{\mathrm{cat}}{ }^{-1}$. The temperature was measured in the centre part of the catalytic bed. The tests were performed for 22 hours at $500{ }^{\circ} \mathrm{C}$. The catalysts after ESR reaction tests were cooled down to the room temperature under the flow of an inert gas. The analysis of the reaction mixture and the reaction products (all in the gas phase) was carried out on-line by means of two gas chromatographs, i.e. Bruker 450-GC and Bruker 430-GC. The first one was 
equipped with a TCD detector and two columns, filled with a porous polymer Porapak Q (for all organics, $\mathrm{CO}_{2}$ and $\mathrm{H}_{2} \mathrm{O}$ vapor) and capillary column CP-Molsieve $5 \AA$ (for $\mathrm{CH}_{4}$ and $\mathrm{CO}$ analysis) with helium as a carrier gas. The second chromatograph equipped with a Molsieve $5 \AA ̊$ column and TCD detector, argon as a carrier gas was used for determination of hydrogen concentration. The conversion of ethanol $\left(\mathrm{X}_{\mathrm{EtOH}}\right)$, water $\left(\mathrm{X}_{\mathrm{H}_{2} \mathrm{O}}\right)$ and conversion of ethanol into particular carbon-containing products $\left(X_{C P}\right)$ were calculated on the basis of their concentrations before and after the reaction, with a correction introduced for the change in gas volume during the reaction, from the following equations:

$$
\begin{gathered}
X_{E t O H}=\frac{C_{E t O H}^{i n}-C_{E t O H}^{\text {out }} \times K}{C_{E t O H}^{i n}} \times 100 \%, \\
X_{\mathrm{H}_{2} \mathrm{O}}=\frac{C_{\mathrm{H}_{2} \mathrm{O}}^{\text {in }}-C_{\mathrm{H}_{2} \mathrm{O}}^{\text {out }} \times K}{C_{\mathrm{H}_{2} \mathrm{O}}^{\text {in }}} \times 100 \%, \\
X_{C P}=\frac{C_{C P}^{\text {out }} \times K}{(n / 2) C_{E t O H}^{\text {in }}} \times 100 \%,
\end{gathered}
$$

where: $C_{E T O H}^{i n}$ - is the molar concentration of ethanol in the reaction mixture (mol \%), $C_{E t O H}^{\text {out }}$ the molar concentration of ethanol in the post-reaction mixture ( $\mathrm{mol} \%), \mathrm{C}_{\mathrm{H}_{2} \mathrm{O}}^{\mathrm{in}}-$ the molar concentration of water in the reaction mixture (mol \%), $C_{H_{2} O}^{\text {out }}$ - the molar concentration of water in the post-reaction mixture $(\mathrm{mol} \%), C_{C P}^{o u t}$ - the molar concentration of the carboncontaining products in the post-reaction mixture $(\mathrm{mol} \%), n-$ the number of carbon atoms in the carbon-containing molecule of the reaction product, $K$ - the volume contraction factor ( $K$ $=\mathrm{C}_{\mathrm{C}}^{\text {in }} / \mathrm{C}_{\mathrm{C}}^{\text {out }}$, where $C_{C}^{\text {in }}$ and $C_{C}^{\text {out }}$ are the molar concentrations of carbon in the ethanol feed to the reaction and in all carbon-containing compounds, which were present in post reaction gases, respectively). The selectivity of ethanol into individual carbon-containing products was expressed as:

$$
S_{C P}=X_{C P} / X_{E t O H} \times 100 \% .
$$


The selectivity of hydrogen formation was determined from the equation:

$$
S_{\mathrm{H}_{2}}=\frac{C_{H_{2}}^{\text {out }}}{C_{\mathrm{H}_{2}}^{\text {in }}+2 C_{\mathrm{CH}_{4}}^{\text {out }}+2 C_{\mathrm{CH}_{3} \mathrm{CHO}}^{\text {out }}} \times 100 \%
$$

\section{Results and discussion}

\subsection{Phase composition}

X-ray diffraction patterns of zeolite samples are presented in the Fig. 1a. Typical BEA zeolite structure can be inferred from the diffraction lines of HAlBEA and SiBEA [34]. The shape of the most intensive peak (302) of BEA zeolites is similar in both samples. Thus it is difficult to find any differences of the crystallinity of samples. However more detailed inspection of the XRD curves revels, that most significant diffraction line, i.e. (302) located at $2 \theta=22.53$ degree for HAlBEA zeolite is observed at $2 \theta=22.71$ degree for SiBEA sample (Fig. 1b). Similar shifts are visible for other diffraction lines, e.g. (304) line located at $2 \theta=$ 25.38 degree is shifted to $2 \theta=25.57$ degree, (306) line positioned at $2 \theta=28.75$ degree moves to $2 \theta=29.10$ degree. This points out the slight lattice contraction caused by the dealumination. It is interesting that positions of some diffraction lines are the same in both samples, e.g. (006) located at $2 \theta=27.12$ degree. Similar patterns are also observed for zeolites modified with nickel, both recorded for the samples after calcination and reduction. However, a minute shift of (302) diffraction line to $2 \theta=22.45$ degree may indicate slight expansion of HAlBEA zeolite upon introduction of nickel and subsequent calcination of the sample. This effect may result from the incorporation of nickel ions into the lattice framework or location of nickel oxide nanoparticles in the zeolite channels. The covalent radius of $\mathrm{r}\left(\mathrm{Ni}^{2+}\right)$ $=128 \mathrm{pm}$ is larger than the covalent radius $\mathrm{r}\left(\mathrm{Al}^{3+}\right)=121 \mathrm{pm}$. However, well evidenced diffraction lines of $\mathrm{NiO}$ (PDF-4 No. 04-001-9373), visible for $\mathrm{Ni}_{10} \mathrm{HAlBEA}$ zeolite simultaneously indicate the presence of relatively large nickel oxide crystallites. Mean size of 
$\mathrm{NiO}$ crystallites is equal to $22.3 \mathrm{~nm}$ (Table 1 ). Hence, one can assume that $\mathrm{Ni}_{10} \mathrm{HAlBEA}$ zeolite may contain both $\mathrm{Ni}^{2+}$ species embedded within zeolite framework and large $\mathrm{NiO}$ nanoparticles surrounded by the zeolite material. Although the positions of zeolite lattice diffraction lines of $\mathrm{SiBEA}$ and $\mathrm{Ni}_{10} \mathrm{SiBEA}$ are almost the same, wider shape of the most significant peak at $2 \theta=22.71$ degree indicates a slight loss of zeolite crystallinity. Note that the size of $\mathrm{NiO}$ in $\mathrm{Ni}_{10} \mathrm{SiBEA}$ is equal to $4.1 \mathrm{~nm}$, in spite of similar content of nickel in zeolites (9.86 and 9.57 wt. \% in $\mathrm{Ni}_{10} \mathrm{HAlBEA}$ and $\mathrm{Ni}_{10} \mathrm{SiBEA}$, respectively) and it is much smaller than in the $\mathrm{Ni}_{10} \mathrm{HAlBEA}$ catalyst (Table 1).

The crystallinity of $\mathrm{Ni}_{10} \mathrm{HAlBEA}$ zeolite is not distorted by the reduction process. The position and shape of XRD peaks observed for reduced $\mathrm{Ni}_{10} \mathrm{HAlBEA}$ are almost the same as for calcined one. The reduction of $\mathrm{Ni}_{10} \mathrm{HAlBEA}$ zeolite at $600{ }^{\circ} \mathrm{C}$ leads to the formation of $\mathrm{Ni}^{0}$ crystallites of the mean size of $30.2 \mathrm{~nm}$ (determined by the XRD method, Table 2). This process include transformation of large $\mathrm{NiO}$ nanoparticles and $\mathrm{Ni}(\mathrm{II})$ species located in the zeolite framework into the metallic nickel nuclei, followed by their agglomeration. The size of $\mathrm{Ni}^{0}$ nanoparticles formed under the same reduction conditions in $\mathrm{Ni}_{10} \mathrm{SiBEA}$ is equal to 4.3 nm (Table 2). Simultaneously stronger broadening of BEA(302) peak indicates more evident changes of $\mathrm{Ni}_{10} \mathrm{SiBEA}$ zeolite crystallinity. The obtained results point out that removal of $\mathrm{Al}$ during dealumination process led to the formation of the specific sites which may strongly interact with nickel precursor and hinder agglomeration of nickel species into the large nanoparticles during calcination and reduction.

\subsection{Structural and surface properties}

TEM images of $\mathrm{Ni}_{10} \mathrm{HAlBEA}$ and $\mathrm{Ni}_{10} \mathrm{SiBEA}$ zeolite catalysts, presented in the Fig. 2, show that nickel crystallites are dispersed on the regular individual zeolite support grains of 
the size from about 30 to $60 \mathrm{~nm}$. Studies confirm general trends outlined in the previous section.

In the case of $\mathrm{Ni}_{10} \mathrm{HAlBEA}$ zeolite, both large (the size above $50 \mathrm{~nm}$ ) and small (below 5 nm) nickel crystallites can be distinguished. The function of crystallite size distribution is relatively wide (Fig. 2e). The predominant contribution is observed for nickel crystallites in the range of $20-30 \mathrm{~nm}\left(d_{N i}^{T E M}=22.5 \mathrm{~nm}\right)$. STEM images (Fig. 2b) indicate that large crystallites are located on the external part of HAlBEA zeolite grains. Detailed inspection of the TEM images of higher resolution (Fig. 2a) points out that some very small nickel crystallites can be located in the inner part of zeolite particles.

In contrast, $\mathrm{Ni}_{10} \mathrm{SiBEA}$ catalyst contains very small nickel crystallites of the predominant size $2-8 \mathrm{~nm}, d_{N i}^{T E M}=7.3 \mathrm{~nm}$ (Fig. 2e). Nickel crystallites are uniformly distributed in the $\mathrm{Ni}_{10}$ SiBEA zeolite (Fig. 2c, 2d). STEM images (Fig. 2b and 2d) evidence uniform distribution of silicon, aluminium and oxygen atoms within HAlBEA zeolite particles, and only silicon and oxygen atoms within SiBEA particles.

Nitrogen adsorption-desorption isotherms and pore size distribution of zeolite supports and Ni-containing zeolite catalysts prior to the reduction are presented in Fig. 3. Large increase of the adsorption values at high partial pressures and the occurrence of slight changes of the shape of hysteresis loops point out slight differences of meso- and micro-porous structure of materials. The decrease of adsorption value at low relative pressures (below $p / p^{0}$ $=0.05$ ) upon dealumination may indicate the loss of microporosity. Such effect can be related to the partial distortion of initial BEA pore structure. An introduction of nickel to HAlBEA zeolite with subsequent calcination leads to the slight decrease of microporosity. This effect can be ascribed both to the partial incorporation of $\mathrm{Ni}^{2+}$ to the zeolite framework, and thus shrinkage of the pores, as well as partial blocking of zeolite channels by NiO crystallites. Such changes are less evident in the catalysts with SiBEA support. 
Fig. 4 shows FTIR-PAS spectra of the samples. Several characteristic O-H stretching vibration bands are observed for HAlBEA and SiBEA zeolites. Note that the spectra were recorded for the samples at room temperature, hence some individual vibration bands could be overlapped with intensive vibration bands of H-bonded hydroxyl groups and physically adsorbed water, located at around $\sim 3520, \sim 3420 \mathrm{~cm}^{-1}$ and $\sim 3200 \mathrm{~cm}^{-1}$. The spectra for both zeolite supports show slight vibration bands located at $3747 \mathrm{~cm}^{-1}$ which can be attributed to the internal isolated $\mathrm{Si}-\mathrm{OH}$ groups. The intensity of the strong vibration bands located between 3700 and $3600 \mathrm{~cm}^{-1}$ become weaker upon dealumination. This can be attributed to the removal of Al-OH groups (with vibration bands at $\sim 3660 \mathrm{~cm}^{-1}$ ), and bridging hydroxyls $\mathrm{Al}-\mathrm{O}(\mathrm{H})-\mathrm{Si}\left(\sim 3610 \mathrm{~cm}^{-1}\right)$. The relative increase of the vibration bands located at $\sim 3520 \mathrm{~cm}^{-1}$ can be attributed to the $\mathrm{H}$-bonded $\mathrm{Si}-\mathrm{OH}$ groups [26]. $\mathrm{Ni}_{10} \mathrm{HAlBEA}$ and $\mathrm{Ni}_{10} \mathrm{SiBEA}$ after drying show weaker vibration bands of isolated $\mathrm{Si}-\mathrm{OH}$ and $\mathrm{Al}-\mathrm{O}(\mathrm{H})-\mathrm{Si}$ groups in the range $3760-3650 \mathrm{~cm}^{-1}$. The presence of nickel precursor in the $\mathrm{Ni}_{10} \mathrm{SilBEA}$ zeolite catalyst drives to the increase in the vibration intensity of H-bonded hydroxyl bands with maximum at $~ 3560$ $\mathrm{cm}^{-1}$, whereas in the case of $\mathrm{Ni}_{10} \mathrm{HAlBEA}$, the vibration bands in this region are much weaker, and moreover new maxima can be found at $\sim 3520$ and $3445 \mathrm{~cm}^{-1}$. The bending hydroxyl group vibrations $\left(\delta_{\mathrm{OH}}\right)$ with maximum located at $1628 \mathrm{~cm}^{-1}$ for HAlBEA are more intensive than similar vibrations in SiBEA sample (with maximum located at $1631 \mathrm{~cm}^{-1}$ ). The peaks representing $\delta_{\mathrm{OH}}$ vibration bands in the nickel containing samples after drying, especially for $\mathrm{Ni}_{10} \mathrm{SiBEA}$ dried sample, are much wider. Bentaleb et al. argued that an impregnation of silica support with an aqueous solution of nickel nitrate can lead to the development of crystalline nitrate phases $\left[\mathrm{Ni}\left(\mathrm{H}_{2} \mathrm{O}\right)_{6}\right]\left(\mathrm{NO}_{3}\right)_{2}$ and $\left[\mathrm{Ni}\left(\mathrm{H}_{2} \mathrm{O}\right)_{5.5}\right]\left(\mathrm{NO}_{3}\right)_{2}$ [35].

The development and transformation of such phases into the zeolite lattice bonded $\mathrm{Ni}$ (II) species or bulk $\mathrm{NiO}$ crystallites can be related to the surface properties of zeolite support. The vibration bands of nickel nitrate in the $\mathrm{Ni}_{10} \mathrm{HAlBEA}$ dried sample is visible as the doublet 
with maximum at 1409 and $1339 \mathrm{~cm}^{-1}$. This picture is similar to the bulk nickel nitrate [36]. In the case of $\mathrm{Ni}_{10} \mathrm{SiBEA}$ the wide peaks with maxima located at 1478, 1440, 1393, and 1325 $\mathrm{cm}^{-1}$ can be found. In the samples after calcination such maxima are not observed, which confirm complete transformation of nitrates into the suitable $\mathrm{Ni}-\mathrm{O}$ or $-\mathrm{Ni}-\mathrm{O}-\mathrm{Si}$ - species.

Wide absorption band between 1250 and $1000 \mathrm{~cm}^{-1}$ can be ascribed to the presence of asymmetric stretching vibrations of Si-O-Si bridges, regarded often as "external" (1250 $\left.1200 \mathrm{~cm}^{-1}\right)$ and "internal" $\left(1100-1000 \mathrm{~cm}^{-1}\right)$ [37]. The presence of distinct peaks in the range of 1250 and $1000 \mathrm{~cm}^{-1}$ in the HAlBEA and $\mathrm{Ni}_{10} \mathrm{HALBEA}$ may indicate the occurrence of $\mathrm{Q}^{4}$ silica oligomeric species. Upon dealumination one can observe a slight widening of such peaks, which can be attributed to the appearance of $\mathrm{Q}^{3}$ silica oligomeric species [37]. The absorption bands at $780-830 \mathrm{~cm}^{-1}$, and around $550-650 \mathrm{~cm}^{-1}$ are the symmetric stretching vibrations of Si-O-Si bridges, while the band at $955-980 \mathrm{~cm}^{-1}$ can be attributed to the stretching vibrations of the $\mathrm{Si}-\mathrm{OH}$ groups. The bands located at $440-480 \mathrm{~cm}^{-1}$ can be assigned to the Si-O bending vibration [38]. In the pure silica material (SiBEA sample) the intensity of the stretching vibrations of the $\mathrm{Si}-\mathrm{OH}$ groups is much stronger than in the HAlBEA and nickel modified zeolites. It is interesting that such vibrations bands are observed (although with weaker intensities) in the samples after nickel incorporation prior to the calcination.

The general conclusion outlined in the XRD and FTIR-PAS on the state of nickel catalysts on the BEA zeolites as supports before and after dealumination well correspond to the detailed studies performed by the application of ${ }^{1} \mathrm{H},{ }^{29} \mathrm{Si}$ and ${ }^{27} \mathrm{Al}$ MAS NMR studies.

The ${ }^{27} \mathrm{Al}$ NMR spectra of HAlBEA zeolite have 4 resonances (Fig. 5). The resonances at 54.8 and $52.5 \mathrm{ppm}$ correspond to two types of aluminum atoms in the tetrahedral environment of the framework. The resonances at -1.7 and $-10 \mathrm{ppm}$ correspond to two types of aluminum atoms in an octahedral environment. The first is a thin peak, then it can be attributed to 
aluminum in a tetrahedral environment surrounded by water molecules. The second is a broad peak that may be attributable to extraframework species. Due to dealumination, the ${ }^{27} \mathrm{Al}$ NMR spectrum of SiBEA zeolite (Fig. 5) has only one small contribution of framework aluminum atoms in the tetrahedral environment $[27,39]$. The ${ }^{27} \mathrm{Al}$ MAS NMR spectrum of $\mathrm{Ni}_{10} \mathrm{AlBEA}$ is a little different from that of HAlBEA, loss of resolution and increase the width at mid-height of the peaks. These modifications come from the paramagnetic properties of $\mathrm{NiO}$, which indicates aproximity between the species. $\mathrm{NiO}$ is an antiferromagnetic oxide at low temperature but becomes paramagnetic at higher temperatures. This temperature depends on the size of the particles $[40,41]$. It is known that the presence of paramagnetic species strongly disrupts the NMR spectra $[42,43]$. There are also changes in the ${ }^{29} \mathrm{Si}$ (spinning sidebands, Fig. S1) and ${ }^{1} \mathrm{H}$ (increased the width, Fig. S2) spectra when nickel is introduced into the HAlBEA zeolite. The ${ }^{27} \mathrm{Al}$ MAS NMR spectrum (Fig. 5) of $\mathrm{Ni}_{10} \mathrm{SiBEA}$ is very similar to spectrum of SiBEA.

The ${ }^{29} \mathrm{Si}$ MAS NMR spectrum of HAlBEA (Fig. S1) shows two peaks at -114.5 and $111.0 \mathrm{ppm}$ due to framework $\mathrm{Si}$ atom in a $\mathrm{Si}(\mathrm{OSi})_{4}\left(\mathrm{Q}^{4}\right)$ environment, located at different crystallographic sites. The $\mathrm{Q}^{3}$ species show two contributions, one signal at $-102.2 \mathrm{ppm}$ for $(\mathrm{OSi})_{3} \mathrm{Si}(\mathrm{OH})$ groups and one signal at $-106.1 \mathrm{ppm}$ for $(\mathrm{OSi})_{3} \mathrm{Si}(\mathrm{Al})$ groups. After dealumination, ${ }^{29} \mathrm{Si}$ MAS NMR spectrum of SiBEA (Fig. S1) is composed of three resonances, -114.5 and $-111.0 \mathrm{ppm}$ for $\mathrm{Q}^{4}$ species and $-102.2 \mathrm{ppm}$ for $\mathrm{Q}^{3}$ species. The contribution of $(\mathrm{OSi})_{3} \mathrm{Si}(\mathrm{Al})$ group $(-106.1 \mathrm{ppm})$ has disappeared [43-45]. The ${ }^{29} \mathrm{Si}$ MAS NMR spectra of $\mathrm{Ni}_{10} \mathrm{AlBEA}$ and $\mathrm{Ni}_{10} \mathrm{SiBEA}$ (Fig. S1) show that incorporation of nickel causes a decrease in the signal corresponding to the $(\mathrm{OSi})_{3} \mathrm{Si}(\mathrm{OH})$ group $(-102.2 \mathrm{ppm})$, which suggests an interaction between the nickel and the silanols of the both zeolites.

The ${ }^{1} \mathrm{H}$ spectra of the HAlBEA zeolite (Fig. S2) shows a main resonance at $4.7 \mathrm{ppm}$ due to bridging hydroxyl protons $(\mathrm{Si}(\mathrm{OH}) \mathrm{Al})$. The low contribution at 1.37 corresponds to 
$\mathrm{Si}(\mathrm{OH})$. In the ${ }^{1} \mathrm{H}$ MAS NMR spectrum of SiBEA (Fig. S2) two main peaks appear at 4.5 and $1.37 \mathrm{ppm}$, due to the protons of $\mathrm{H}$-bonded $\mathrm{Si}-\mathrm{OH}$ groups present at vacant $\mathrm{T}$-atom sites and isolated $\mathrm{Si}-\mathrm{OH}$ groups respectively $[46,47]$. Two peaks at 7 and $3.22 \mathrm{ppm}$ are also present and correspond to protons of water molecules and of $\mathrm{H}$-bonded $\mathrm{Si}-\mathrm{OH}$ groups located in a second type of crystallographic site [48]. In the ${ }^{1} \mathrm{H}$ MAS NMR spectra of $\mathrm{Ni}_{10} \mathrm{HAlBEA}$ and $\mathrm{Ni}_{10} \mathrm{SiBEA}$ (Fig. S2), signals at 4.63 and $4.50 \mathrm{ppm}$ are not observable. The signal is probably too broadened by a paramagnetic effect, which means an interaction between the nickel and the bridging hydroxyl and silanols of the zeolite.

Fig. 6 shows temperature-programmed desorption of ammonia from the surface of reduced samples. Two irregular ammonia desorption peaks $(\mathrm{m} / \mathrm{e}=16)$ are observed for HAlBEA and $\mathrm{Ni}_{10} \mathrm{HAlBEA}$ samples. The first peak, located between 100 and $300{ }^{\circ} \mathrm{C}$ evidences the presence of the large number of weak acid sites. Slight shift of the main maximum to lower temperatures is observed for $\mathrm{Ni}_{10} \mathrm{HAlBEA}$ zeolite catalyst. The second peak spreads from 300 to $500{ }^{\circ} \mathrm{C}$. The removal of $\mathrm{Al}$ from zeolite framework leads to the strong decrease of the number of acid sites both in the SiBEA zeolite and Ni-containing zeolite catalyst ( $\left.\mathrm{Ni}_{10} \mathrm{SiBEA}\right)$. The samples prior to the adsorption of ammonia were reduced. Hence ammonia during desorption from the strong acid sites, i.e. above $300{ }^{\circ} \mathrm{C}$ can be decomposed to nitrogen and hydrogen on nickel crystallites. Such effect is manifested in the appearance of desorption peaks of hydrogen $(\mathrm{m} / \mathrm{e}=2)$ and nitrogen $(\mathrm{m} / \mathrm{e}=28)$, partially overlapped with desorption peaks of ammonia from $\mathrm{Ni}_{10} \mathrm{HAlBEA}$ zeolite catalyst [49]. The lack of high-temperature desorption peaks of hydrogen in the curves of $\mathrm{Ni}_{10} \mathrm{SiBEA}$ catalyst can be connected with low acidity of the support. Small amount of adsorbed ammonia molecules can be converted to nitrogen and hydrogen, which recreates Brønsted hydroxyl on surface of zeolite. It is also interesting that very low desorption peaks of hydrogen at low 
temperatures (100-300 $\left.{ }^{\circ} \mathrm{C}\right)$ may indicate that ammonia during adsorption step may remove hydrogen left on the nickel crystallites after reduction.

The changes of the number and strength of acid sites observed in the TPD $\mathrm{NH}_{3}$ studies are in good correlation with the results of the nature of hydroxyl groups determined by application of DRIFTS and acid sites by FTIR pyridine adsorption studies.

DRIFTS spectra of $\mathrm{Ni}_{10} \mathrm{HAlBEA}$ and $\mathrm{Ni}_{10} \mathrm{SiBEA}$ catalysts in the region of hydroxyl group vibrations are presented in the Fig. 7. DRIFTS spectra of nickel catalysts recorded at room temperature exhibit several bands located at similar positions as in the FTIR-PAS spectra of the corresponding samples. Gradual increase in hydrogen treatment temperature leads to the decrease of intensity of H-bonded hydroxyl groups vibrations and physically adsorbed water, located at around $\sim 3520 \mathrm{~cm}^{-1}, \sim 3420 \mathrm{~cm}^{-1}$ and $\sim 3200 \mathrm{~cm}^{-1}$. The vibration band observed at $3747 \mathrm{~cm}^{-1}$ in the spectra recorded at $20{ }^{\circ} \mathrm{C}$ for $\mathrm{Ni}_{10} \mathrm{HAlBEA}$ catalyst, ascribed to the external isolated silanol ( $\mathrm{SiO}-\mathrm{H})$ group gradually moves to $3732 \mathrm{~cm}^{-1}$ with an increase of treatment temperature. Such effects can be ascribed to the increase of the contribution of vibrations of terminal internal $\mathrm{SiO}-\mathrm{H}$ groups. After high temperature treatment and cooling down to $100{ }^{\circ} \mathrm{C}$ the band appears in the similar position as before treatment, indicating high mobility of such groups in zeolite materials under different reaction conditions. Similar shift is observed for nickel catalyst with dealuminated zeolite support $\mathrm{Ni}_{10} \mathrm{SiBEA}$. However the bands are located at slightly lower wavenumbers, and hence the shift is noticed from $3735 \mathrm{~cm}^{-1}$ to $3725 \mathrm{~cm}^{-1}$. Two well developed vibration bands are observed at elevated temperatures for $\mathrm{Ni}_{10} \mathrm{HAlBEA}$ catalyst, located at around 3660 and $3600 \mathrm{~cm}^{-1}$, and ascribed to extra-framework AlO-H and bridging acidic hydroxyls $\mathrm{Si}-\mathrm{O}(\mathrm{H})-\mathrm{Al}$ groups. In the spectra of the samples cooled down after high temperature reduction to $100{ }^{\circ} \mathrm{C}$, such vibration bands are observed at similar positions. Moreover weak vibration band located at $3705 \mathrm{~cm}^{-1}$ can be detected. The increase of treatment temperature leads to the decrease of the intensity of hydrogen bonded $\mathrm{SiO}-\mathrm{H}$ groups in the 
$\mathrm{Ni}_{10} \mathrm{SiBEA}$ catalyst, located at around $3520 \mathrm{~cm}^{-1}$. Strong vibration band on the spectra of this sample recorded at room temperature is observed at around $3630 \mathrm{~cm}^{-1}$. It can be attributed to the interaction of $\mathrm{SiO}-\mathrm{H}$ groups with $\mathrm{Ni}(\mathrm{II})$ species $[39,50]$. The intensity is gradually decreased with an increase in reduction temperature. After cooling down the sample to $100{ }^{\circ} \mathrm{C}$ only strong vibration band of isolated silanol groups is observed, indicating very low acidity of $\mathrm{Ni}_{10} \mathrm{SiBEA}$ catalyst.

The FTIR spectrum of activated HAlBEA zeolite (Fig. 8) exhibits five characteristic bands in $\mathrm{OH}$ stretching region: at 3780 and $3661 \mathrm{~cm}^{-1}$ attributed to $\mathrm{AlO}-\mathrm{H}$ groups of extraframework aluminum species [51,52], at $3742 \mathrm{~cm}^{-1}$ associated to isolated external $\mathrm{SiO}-\mathrm{H}$ groups [53], at $3608 \mathrm{~cm}^{-1}$ related to bridging hydroxyls $\mathrm{Si}-\mathrm{O}(\mathrm{H})-\mathrm{Al}$ and at around $3550 \mathrm{~cm}^{-1}$ broad band related to $\mathrm{H}$-bonded $\mathrm{SiO}-\mathrm{H}$ groups. The introduction of nickel ions into HAlBEA leads to disappearance of the band at $3780 \mathrm{~cm}^{-1}$ (Fig. 8) suggesting that nickel ions interacts with corresponding hydroxyl groups of HAlBEA.

The treatment of TEABEA with high concentrated nitric acid solution leads to removal of aluminum atoms and appearance in the spectrum of resulted SiBEA a very intense narrow band at $3735 \mathrm{~cm}^{-1}$ related to isolated internal SiO-H groups (Fig. 8) and an intense broad band at $3521 \mathrm{~cm}^{-1}$ due to hydrogen bonded silanol groups suggesting formation of vacant $\mathrm{T}$-atom sites, as reported earlier [54]. The impregnation of SiBEA with aqueous solution of nickel precursor results in decreasing of intensity of $\mathrm{OH}$ bands of isolated internal $\mathrm{SiO}-\mathrm{H}$ groups at $3735 \mathrm{~cm}^{-1}$ and hydrogen bonded silanol groups at $3521 \mathrm{~cm}^{-1}$ (Fig. 8) suggesting that nickel ions react with these silanol groups leading to the incorporation of nickel ions into framework of SiBEA, in line with earlier report [55].

To determine the nature, number and strength of acidic centers of supports and $\mathrm{Ni}$ containing catalysts the FTIR spectra of adsorbed pyridine as probe molecule were recorded. 
The FTIR spectra after adsorption of pyridine at room temperature and then outgassed at 150 ${ }^{\circ} \mathrm{C}$ are given in Fig. 9. For HAlBEA sample very intense, characteristic bands of pyridinium cations are seen at 1636 and $1546 \mathrm{~cm}^{-1}$ suggesting presence of strong Brønsted acidic centers related to proton of $\mathrm{Si}-\mathrm{O}(\mathrm{H})-\mathrm{Al}$ groups. Furthermore, the band at $1455 \mathrm{~cm}^{-1}$ is related to interaction between pyridine molecules and strong Lewis acidic centers $\left(\mathrm{Al}^{+3}\right)$ while the band at $1622 \mathrm{~cm}^{-1}$ may be ascribed to pyridine coordinately bonded to Lewis acidic centers $[56,57]$. Finally, the band at $1490 \mathrm{~cm}^{-1}$ corresponds to $\mathrm{C}-\mathrm{C}$ oscillation of pyridine aromatic ring chemisorbed on both Brønsted and Lewis acid centers. Additionally, presence of small band at $1575 \mathrm{~cm}^{-1}$ may be associated with pyridine coordinately bonded to weak Lewis acidic centers [58].

Introduction of nickel ions into HAlBEA leads to formation of additional amount of Lewis acidic centers related to $\mathrm{Ni}$ (II) species (Fig. 9 and Table 3) confirmed by appearing of intense bands at 1610 and $1450 \mathrm{~cm}^{-1}$ and to decrease of quantity of Brønsted acidic centers evidenced by lower intensity of the bands at 1637 and $1546 \mathrm{~cm}^{-1}$ for $\mathrm{Ni}_{2.0} \mathrm{HAlBEA}$ than HAlBEA (Fig. 9). These phenomena may be explained by some degree of ion exchange of proton of bridging hydroxyls $\mathrm{Si}-\mathrm{O}(\mathrm{H})-\mathrm{Al}$ with nickel ions. As we have recently reported [39], SiBEA contains very small amount of the both Brønsted and Lewis acidic centers due to presence of traces of aluminium atoms remaining after nitric acid treatment. The impregnation of $\mathrm{SiBEA}$ with the aqueous $\mathrm{Ni}\left(\mathrm{NO}_{3}\right)_{2}$ solution leads to increase of amount of Lewis acidic centers evidenced by appearance of FTIR bands at 1610 and $1450 \mathrm{~cm}^{-1}$ probably due to pyridine bonded to isolated nickel(II) species. The results presented in Fig. 9 and Table 3 show that HAlBEA and $\mathrm{Ni}_{10} \mathrm{HAlBEA}$ contain much higher amount of Brønsted and Lewis acidic centers than $\mathrm{SiBEA}$ and $\mathrm{Ni}_{10} \mathrm{SiBEA}$.

\subsection{Reducibility and active surface area of nickel catalysts}


The temperature-programmed-reduction curves are presented in the Fig. 10. Reduction of $\mathrm{Ni}_{10} \mathrm{HAlBEA}$ catalyst goes through two well separated maxima located in the range $300-430$ ${ }^{\circ} \mathrm{C}$ and $430-600{ }^{\circ} \mathrm{C}$. In the case of $\mathrm{Ni}_{10} \mathrm{SiBEA}$ catalyst, the first maximum can be distinguished between $250-350{ }^{\circ} \mathrm{C}$, the second maximum is located between 350 and 600 ${ }^{\circ} \mathrm{C}$. Small amounts oxide phases are reduced above $600{ }^{\circ} \mathrm{C}$. Complex shape of the TPR curves has been usually regarded as indication of the reduction of nickel oxide phases of different metal-oxygen interactions in accordance to the reaction equation: $\mathrm{NiO}+\mathrm{H}_{2} \rightarrow \mathrm{Ni}^{0}+\mathrm{H}_{2} \mathrm{O}$. Low temperature peaks may indicate the reduction of large $\mathrm{NiO}$ crystallites (regarded as "free" or "bulk-like" NiO"). While high-temperature reduction peaks can be ascribed to the reduction of nickel aluminate or nickel silicate species. The interfacial border between $\mathrm{NiO}$ particles and the support increases with the decrease of the size of $\mathrm{NiO}$ crystallites, which may facilitate diffusion of nickel species to the support during thermal treatment [59]. A complex shape of TPR curves of nickel zeolites has been also explained by the successive reduction of $\mathrm{Ni}(\mathrm{II})$ and $\mathrm{Ni}(\mathrm{I})$ species in accordance to the reaction equations $\mathrm{Ni}^{2+}+1 / 2 \mathrm{H}_{2} \rightarrow$ $\mathrm{Ni}^{+}+\mathrm{H}^{+}$; followed by $\mathrm{Ni}^{+}+1 / 2 \mathrm{H}_{2} \rightarrow \mathrm{Ni}^{0}+\mathrm{H}^{+}$), in which the evolved protons take part in the reaction with lattice oxygen, giving hydroxyl group $n(\mathrm{Si}, \mathrm{Al}) \mathrm{O}+n \mathrm{H}^{+} \rightarrow n(\mathrm{Si}, \mathrm{Al}) \mathrm{OH}$ [39].

The temperature programmed desorption curves of hydrogen from the surface of catalysts are presented in the Fig. 11. Wide desorption peak of low intensity observed for $\mathrm{Ni}_{10} \mathrm{HAlBEA}$ catalyst is located between -60 and $500{ }^{\circ} \mathrm{C}$. Desorption of hydrogen from the surface of $\mathrm{Ni}_{10} \mathrm{SiBEA}$ catalyst is much higher. Irregular and large desorption peak is located in the similar temperature region as in the $\mathrm{Ni}_{10} \mathrm{HAlBEA}$ catalyst. The complex shape of TPD curves is usually ascribed to the presence of sites with different $\mathrm{Ni}-\mathrm{H}$ bond strength [61]. One can observe pronounced contribution of weak adsorption sites on the surface of $\mathrm{Ni}_{10} \mathrm{SiBEA}$ catalyst. The active surface area of $\mathrm{Ni}_{10} \mathrm{HAlBEA}$ catalyst $\left(S_{a}\right)$, calculated by the integration of the low-temperature peak $\left(-60-500{ }^{\circ} \mathrm{C}\right)$ is equal to $1.4 \mathrm{~m}^{2} / \mathrm{g}$, while in the case of $\mathrm{Ni}_{10} \mathrm{SIBEA}$ 
$S_{a}$ it is equal to $6.1 \mathrm{~m}^{2} / \mathrm{g}$. High temperature peaks (in the range $500-800{ }^{\circ} \mathrm{C}$ ) are observed on the TPD curves of both catalysts. Their presence can be attributed to the formation of hydrogen in the reaction of the oxidation of nickel with hydroxyl groups located on the support [62]. Taking into account similar content of nickel, much smaller active surface area of $\mathrm{Ni}_{10} \mathrm{HAlBEA}$ catalyst, and the same the presence of larger nickel crystallites and shorter Ni-support border line in the $\mathrm{Ni}_{10} \mathrm{HAlBEA}$ catalysts, one can suppose that HAlBEA zeolite, i.e. the support of high acidity and activity of hydroxyl groups, can influence the oxidation degree of nickel surface atoms to a much greater extent than SiBEA. High activity of the HAlBEA support in the surface reoxidation processes of nickel crystallites may to some extent facilitate initial stages of ESR reaction or even retard carbon deposit formation. On the other hand, large number of acid sites on such support may contribute in the transformation of ethanol and intermediate products towards coke precursors.

\subsection{Catalytic performance in the steam reforming of ethanol}

Preliminary studies of HAlBEA and SiBEA zeolites showed their high activity in ethanol conversion under applied reaction conditions, i.e. at $500{ }^{\circ} \mathrm{C}$ in the reaction mixture of high molar ratio $\mathrm{H}_{2} \mathrm{O} / \mathrm{C}_{2} \mathrm{H}_{5} \mathrm{OH}=12 / 1$ (Fig. 12). Almost complete ethanol conversion ( $X_{E T O H}=100 \%$ ) is observed for long time-on-stream for both zeolites (Fig. 12a). However practically no water conversion is seen (Fig. 12b). The main reaction product in the presence of HAlBEA and SiBEA zeolites, in spite of their different acidity, is ethylene ( $S_{C_{2} \mathrm{H}_{4}}=\sim 98 \%$ ) (Fig.12f), which indicates the predominant role of ethanol dehydration reaction: $\mathrm{C}_{2} \mathrm{H}_{5} \mathrm{OH} \rightarrow$ $\mathrm{C}_{2} \mathrm{H}_{4}+\mathrm{H}_{2} \mathrm{O}$ [63]. Small amounts of propane $\left(S_{C_{3} H_{8}}=\sim 6 \%\right)$ in the presence of HAlBEA zeolite are initially formed, which probably results from the consecutive reactions of ethylene. Direct production of C2-C4 olefins and higher hydrocarbons (gasoline-range) by the conversion of bioethanol (ethanol to gasoline, ETG) has recently gained great interests [64- 
68]. Formation of propane can be directly related to the higher acidity of HAlBEA zeolite. Such processes were less evident in the presence of dealuminated zeolite, and only small amounts of acetaldehyde were initially formed $\left(S_{\mathrm{CH}_{3} \mathrm{CHO}}=\sim 2 \%\right)$. One can suppose that the gradual drop of selectivity to propane with the time-on-stream for HAlBEA zeolite was related the deposition of coke on the acid sites. Thus partial deactivation of zeolite led to the blocking of the sites which were active in the subsequent transformation of ethylene to hydrocarbons. Detailed discussion of the nature of carbonaceous deposit formed in such process is presented in the next section. One can state that dealumination of BEA zeolite can be regarded as useful method of the development of catalysts for ethylene production by the use of cheap dilute aqueous solutions of ethanol in biorefineries $[69,70]$. We have confirmed that introduction of large amounts of water to the bioethanol feed can suppress formation of higher hydrocarbons and large amounts of carbon deposit at high temperatures, especially on the the SiBEA zeolite.

Nickel catalysts $\mathrm{Ni}_{10} \mathrm{HAlBEA}$ and $\mathrm{Ni}_{10} \mathrm{SiBEA}$ show high activity in the ESR reaction performed at $500{ }^{\circ} \mathrm{C}$. Complete ethanol conversion is observed over both catalysts for long time-on-stream (22 h tests). Initial water conversion $\left(X_{\mathrm{H}_{2} \mathrm{O}}\right)$ regardless of the type of catalysts is equal $40 \%$. Lower conversion of water than ethanol $\left(X_{E t O H}\right)$ results from the excess of water in relation to the reaction stoichiometry and occurrence of parallel reactions, such as ethanol dehydration and dehydrogenation $\left(\mathrm{C}_{2} \mathrm{H}_{5} \mathrm{OH} \rightarrow \mathrm{CH}_{3} \mathrm{CHO}+\mathrm{H}_{2}\right)$. The drop of water conversion to about $X_{\mathrm{H}_{2} \mathrm{O}}=10 \%$ in the presence of $\mathrm{Ni}_{10} \mathrm{HAlBEA}$ catalyst occurs during the initial $5 \mathrm{~h}$ time-on-stream. Whereas dealuminated nickel catalyst $\left(\mathrm{Ni}_{10} \mathrm{SiBEA}\right)$ shows higher durability, and $X_{\mathrm{H}_{2} \mathrm{O}}$ remains on the initial level for more than $20 \mathrm{~h}$. $\mathrm{Ni}_{10} \mathrm{HAlBEA}$ catalyst shows higher initial selectivity to $\mathrm{H}_{2}, \mathrm{CO}_{2}$, and lower selectivity to $\mathrm{CH}_{4}$ than $\mathrm{Ni}_{10} \mathrm{SiBEA}$. However, strong decrease of selectivity of $\mathrm{Ni}_{10} \mathrm{HAlBEA}$ catalyst to $\mathrm{H}_{2}$ (from $90 \%$ to about 60 
$\%$ ), $\mathrm{CO}_{2}$ (from $65 \%$ to $30 \%$ ), slight decrease of selectivity to $\mathrm{CH}_{4}$ (from $25 \%$ to $2-3 \%$ ), $\mathrm{CO}$ (from $10 \%$ to $\sim 3 \%$ ), and pronounced increase in selectivity to ethylene (from zero to $\sim 65 \%$ ) is observed with the time-on-stream. Moreover, additional compounds appear in the reaction product mixture, such as acetaldehyde, ethane and propane. Although initial selectivity of $\mathrm{Ni}_{10} \mathrm{SiBEA}$ catalyst to $\mathrm{H}_{2}\left(S_{\mathrm{H}_{2}}=75 \%\right)$ is smaller than $\mathrm{Ni}_{10} \mathrm{HAlBEA}$ catalyst, it is not so strongly decreased with the time on-stream. Similar trend is observed for $\mathrm{CO}_{2}$ selectivity. $\mathrm{Ni}_{10} \mathrm{SiBEA}$ catalyst shows slightly smaller initial selectivity to $\mathrm{CO}_{2}$ than $\mathrm{Ni}_{10} \mathrm{HAlBEA}$ (55 and $65 \%$, respectively). $\mathrm{CO}_{2}$ selectivity remains on the same level for long-time-on stream, and only small drop is observed after $20 \mathrm{~h}$ of the reaction test. $\mathrm{Ni}_{10} \mathrm{SiBEA}$ catalyst, in spite of lower initial selectivity to $\mathrm{H}_{2}\left(S_{\mathrm{H}_{2}}=\sim 65 \%\right)$ and $\mathrm{CO}_{2}\left(S_{\mathrm{CO}_{2}}=\sim 55 \%\right)$ shows better durability than $\mathrm{Ni}_{10} \mathrm{HAlBEA}$. No ethylene and acetaldehyde production is observed for relatively long time. $\mathrm{Ni}_{10} \mathrm{SiBEA}$ catalyst, in contrast to the $\mathrm{Ni}_{10} \mathrm{HAlBEA}$, displays high selectivity to methane $\left(S_{\mathrm{CH}_{4}}=\sim 35 \%\right)$ and carbon monoxide $\left(S_{C O}=\sim 10 \%\right)$. Partial deactivation of is observed after $20 \mathrm{~h}$ of the time-on-stream.

The catalysts were reduced before ESR reaction, hence the presence of nickel metallic nanoparticles influenced the route of catalytic reactions. The product selectivity was different from that observed for pure or unreduced nickel-modified zeolites in the conversion of diluted bioethanol solutions, where reaction was conducted towards ethylene or higher hydrocarbons $[70,71]$ The main initial reaction products in the steam reforming of ethanol in the presence of reduced $\mathrm{Ni}_{10} \mathrm{HAlBEA}$ and $\mathrm{Ni}_{10} \mathrm{SiBEA}$ catalysts were hydrogen and carbon dioxide. Formation of side reaction products, such as methane and carbon monoxide can be ascribed to the direct decomposition of ethanol $\left(\mathrm{C}_{2} \mathrm{H}_{5} \mathrm{OH} \rightarrow \mathrm{H}_{2}+\mathrm{CH}_{4}+\mathrm{CO}\right)$ or acetaldehyde $\left(\mathrm{CH}_{3} \mathrm{CHO} \rightarrow \mathrm{CH}_{4}+\right.$ $\mathrm{CO}$ ) on the surface of nickel crystallites. The presence of $\mathrm{CO}$ in the reaction products can be also connected with conversion of ethanol or formed acetaldehyde with participation of the smaller number of water molecules $\left(\mathrm{C}_{2} \mathrm{H}_{5} \mathrm{OH}+\mathrm{H}_{2} \mathrm{O} \rightarrow 4 \mathrm{H}_{2}+2 \mathrm{CO}, \mathrm{CH}_{3} \mathrm{CHO}+\mathrm{H}_{2} \mathrm{O} \rightarrow 3 \mathrm{H}_{2}\right.$ 
$+\mathrm{CO})$, and low activity of catalysts in consecutive water-gas shift reaction $\left(\mathrm{CO}+\mathrm{H}_{2} \mathrm{O} \rightarrow\right.$ $\mathrm{CO}_{2}+\mathrm{H}_{2}$ ). High nickel dispersion has been often regarded as the most important feature of ESR nickel catalysts [72,73]. The decrease of nickel crystallite size led to the increase of the number of active sites, as well as to the changes of their nature, related with different crystallites geometry and contribution of suitable sites (face, edge and corner atoms) [74,75]. An improved activity, selectivity, as well as better sintering and coking resistance has been often demonstrated for the catalysts with the small crystallites in the ESR reaction [72,73]. It was demonstrated above, that both $\mathrm{Ni}_{10} \mathrm{HAlBEA}$ and $\mathrm{Ni}_{10} \mathrm{SiBEA}$ catalysts showed high initial activity in the ethanol steam reforming reaction. Both catalysts contained very small crystallites, below $10 \mathrm{~nm}$ (Fig. 2). However crystallite size distribution was much wider for $\mathrm{Ni}_{10} \mathrm{HAlBEA}$. Large crystallites were visible near very small ones in this catalyst, and participated in the ESR reaction. It is interesting that in spite of lower mean nickel crystallite size, narrower crystallite size distribution, and much higher active surface area, $\mathrm{Ni}_{10} \mathrm{SiBEA}$ catalyst showed lower initial $\mathrm{H}_{2}$ and $\mathrm{CO}_{2}$ selectivity. This effect can be explained by the influence of support. The presence of Brønsted acid sites increased ability of $\mathrm{Ni}_{10} \mathrm{HAlBEA}$ catalyst in ethanol and water activation and their interaction with the surface intermediates, formed on the nickel crystallites. Simultaneously, the enhanced activation of ethanol by the sites on the $\mathrm{Ni}_{10} \mathrm{HAlBEA}$ catalyst led to the dehydration reaction, formation of ethylene and then development of coke with the time-on-stream on the acid sites. The presence of carbonaceous deposits in zeolite pores could also resulted in some diffusion limitation. Such effects may explain gradual drop of selectivity to $\mathrm{H}_{2}$ and $\mathrm{CO}_{2}$ during a few hours of the reaction test observed for $\mathrm{Ni}_{10} \mathrm{HAlBEA}$ catalyst. Similar phenomena were observed by Sánchez-Sánchez et al. who achieved lower acidity and better nickel dispersion of $\mathrm{Ni} / \mathrm{Al}_{2} \mathrm{O}_{3}$ by the introduction of $\mathrm{Mg}$ [76]. Similar effects, i.e. the inhibition of ethanol dehydration 
reaction to ethylene, increase in $\mathrm{CO}_{2}$ selectivity and improved coking resistance of catalysts in ESR reaction were achieved by Denis et al. through the introduction of sodium [77].

\subsection{The nature of carbon deposits}

TEM and STEM images of nickel catalysts after ESR reaction tests performed at $500{ }^{\circ} \mathrm{C}$ are presented in the Fig. 13. Several forms carbon deposits can be found on the images of $\mathrm{Ni}_{10} \mathrm{HAlBEA}$ catalyst (Fig. 13a). Filaments of different diameter, length and internal structure are well visible. Some nickel crystallites are located on the top of filaments or surrounded by carbonaceous material. The inset in the Fig. 13a shows the image of the filaments with regular, fishbone-like structure of external parts and less ordered inner parts. It is difficult to estimate nickel crystallite size from TEM images, part of them seems to be disintegrated into the smaller particles. The microstructure of zeolite particles is less regular than in the sample before the ESR reaction test (Fig. 2a). Most of them seem to be surrounded by amorphous carbon. Filamentous carbon is almost not visible on the $\mathrm{Ni}_{10} \mathrm{SiBEA}$ images after ESR reaction test (Fig. 13c,d). One can find only on the bottom part of the image (Fig. 13c) small amounts of thin rather uniform filaments, with the size corresponding to the size of the small nickel nanoparticles.

FTIR-PAS spectra of the supports and nickel catalysts after reaction tests are presented in the Fig. 14. It is difficult to find strong $\mathrm{C}-\mathrm{H}$ vibrations, typical for organic compounds. Hence one can assume that samples contain carbon deposits with high $\mathrm{C} / \mathrm{H}$ ratio. Small absorption bands located between 2000 and $1400 \mathrm{~cm}^{-1}$ can be ascribed to the stretching vibrations of carbonyl groups in surface intermediate species and bending vibrations of hydroxyl groups $\left(\delta_{\mathrm{OH}}\right)$, as well as conjugated olefins, polycondensed aromatics, and deformation vibrations of $\mathrm{CH}_{\mathrm{x}}$ groups [78]. Low intensities of such vibrations in the $\mathrm{Ni}_{10} \mathrm{HAlBEA}$ catalyst can indicate partial removal of hydroxyl groups, resulted from the presence of carbon deposits. Slight 
differences of the shape of absorption bands located between 1250 and $1000 \mathrm{~cm}^{-1}$, related with stretching vibrations of Si-O-Si bridges and the bands between 955 and $980 \mathrm{~cm}^{-1}$, ascribed to the vibrations of the Si-OH groups after activation (Fig. 4) and ESR reaction (Fig. 14) can indicate, that the microstructure of most zeolites has not been strongly changed during reaction. However more pronounced changes, visible for $\mathrm{Ni}_{10} \mathrm{HAlBEA}$ catalyst may confirm partial breakdown of original microstructure. It is worth to note that the catalytic tests were performed under severe conditions to intensify deactivation phenomena, performing tests at high temperatures, using high ethanol weight hourly space velocity $\left(\mathrm{WHSV}_{\mathrm{EtOH}} \approx 9.5 \mathrm{~g}_{\mathrm{EtOH}} \mathrm{h}^{-1}\right.$ $\mathrm{g}_{\mathrm{cat}}{ }^{-1}$ ) and undiluted reaction mixture with inert gas.

The Raman spectra of the supports and nickel catalysts after steam reforming reaction performed at $500{ }^{\circ} \mathrm{C}$ are shown in Fig. 15. Several peaks are distinguished on the Raman spectra of unmodified HAlBEA zeolite. Weak vibrations near $2700-3000 \mathrm{~cm}^{-1}$ were detectable. Such vibrations can be ascribed to the $\mathrm{C}-\mathrm{H}$ bonds in carbon deposits and to overtone of D-band [79]. The irregular shapes of peaks with maxima at ca. 1604, 1365, and $1200 \mathrm{~cm}^{-1}$ indicate superposition of vibrations of different carbon-containing groups. The asymmetric peak located between 1670 and $1500 \mathrm{~cm}^{-1}$ can be ascribed to the $\mathrm{C}=\mathrm{C}$ stretching vibrations of $\mathrm{sp}^{2} \mathrm{C}=\mathrm{C}$ bonds, in the conjugated olefin and aromatic species - near $1600 \mathrm{~cm}^{-1}$, and to $\mathrm{E}_{2 \mathrm{~g}}$ carbon-carbon in plane in-plane stretching vibration in graphite-like deposits close to $1570 \mathrm{~cm}^{-1}$, designated as G-band. Wide peaks in the range $1500-1100 \mathrm{~cm}^{-1}$ has been often ascribed in the literature to the vibrations of $\mathrm{CH}_{3}$ group, vibration of olefin and aromatic species, and also to some defects in the structural units of graphite-like deposits, referred as the D-band [80]. D-band has been has been often correlated with breathing modes of $\mathrm{sp}^{2}$ atoms in carbon rings [81]. The lack of such strong vibration bands for SiBEA zeolite points out that carbon was not formed during ESR reaction test. The colour of the SiBEA sample was not changed during the ESR reaction test, while HAlBEA sample became grey. Studies 
confirm high durability of dealuminated SiBEA zeolites in the conversion of diluted solution of ethanol to ethylene at $500{ }^{\circ} \mathrm{C}$, and this reaction can be proceed without formation of carbonaceous deposits with the long-time-on-stream. In turn, the presence of water does not eliminate formation of discussed above olefin and aromatic species, as well as graphite-like deposits resulted from the ethylene oligomerization, aromatization and then cracking of hydrocarbons on the HAlBEA zeolites.

Strong Raman vibration bands are observed for nickel catalysts. The shape and position of the peaks is slightly different from that presented for pure HAlBEA zeolite. In part, the nature of carbon deposits in the $\mathrm{Ni}_{10} \mathrm{HAlBEA}$ results from similar reactions, initiated by ethanol dehydration on the acidic sites of the support to ethylene, and then oligomerization and transformation to coke. The peaks in the range $1600-1500 \mathrm{~cm}^{-1}$ can indicate the presence of the conjugated olefin and aromatic species, and more graphitic-like structures, deposited on the support (G-band). However taking into account wide discussion in the literature [82-85] and presented above TEM results, one can assume that vibrations in this region may also indicate $\mathrm{sp}^{2}$ vibrations in graphitic carbon structures of different disorder, i.e. highly ordered structures in carbon filaments and surface films (at ca. 1580, $1570 \mathrm{~cm}^{-1}$ ), nanocrystalline graphite (at ca. $1600 \mathrm{~cm}^{-1}$ ), amorphous carbon and $\mathrm{CH}_{\mathrm{x}}$ groups (at ca. $1490 \mathrm{~cm}^{-1}$ ) [81]. Similar vibrations bands are observed for $\mathrm{Ni}_{10} \mathrm{SiBEA}$ catalyst. However, several features of the spectra indicate more diverse nature of carbon structures in the $\mathrm{Ni}_{10} \mathrm{HAlBEA}$ catalyst. Gpeak in the $\mathrm{Ni}_{10} \mathrm{HAlBEA}$ is wider than in the $\mathrm{Ni}_{10} \mathrm{SiBEA}$, which is often regarded as indication of disorder [81]. Similar conclusions can be derived comparing the ratio of intensities of $\mathrm{D}$ to $\mathrm{G}$ bands, $\mathrm{I}(\mathrm{D}) / \mathrm{I}(\mathrm{G})=1$ for $\mathrm{Ni}_{10} \mathrm{HAlBEA}$ and $\mathrm{I}(\mathrm{D}) / \mathrm{I}(\mathrm{G})=0.7$ for $\mathrm{Ni}_{10} \mathrm{SiBEA}$ catalysts, respectively.

We have evidenced that the use of dealuminated BEA zeolite as support for nickel catalysts led to the pronounced increase of durability in the ESR reaction. However, the key 
question, what is the most important factor responsible for improved performance of obtained catalysts in the ESR reaction seems to be still open. Carbon deposit formation is regarded as one of the most crucial reasons of catalysts deactivation in the ESR reaction. In general it can be formed as result of Boudouard reaction $\left(2 \mathrm{CO} \rightarrow \mathrm{CO}_{2}+\mathrm{C}\right)$, methane decomposition $\left(\mathrm{CH}_{4}\right.$ $\left.\rightarrow \mathrm{C}+2 \mathrm{H}_{2}\right)$, decomposition or polymerization or of ethylene $\left(\mathrm{C}_{2} \mathrm{H}_{4} \rightarrow 2 \mathrm{C}+\mathrm{H}_{2}, \mathrm{C}_{2} \mathrm{H}_{4} \rightarrow\right.$ coke), aldol condensation of acetaldehyde $\left(\mathrm{CH}_{3} \mathrm{CHO} \rightarrow\right.$ coke $)$ or condensation of acetone to mesitil oxide $\left(2 \mathrm{CH}_{3} \mathrm{CCH}_{3} \mathrm{OH} \rightarrow\left(\mathrm{CH}_{3}\right)_{2} \mathrm{C}(\mathrm{OH}) \mathrm{CH}_{2} \mathrm{COCH}_{3} \rightarrow\left(\mathrm{CH}_{3}\right)_{2} \mathrm{CCHCOCH}_{3}+\mathrm{H}_{2} \mathrm{O}\right)$ $[13,14,86]$. The growth of filamentous carbon deposits starts from the migration of carbon atoms on the surface of nickel crystallite and formation of graphitic layers, which can expel crystallite from the support. The retardation of such initial processes can be achieved by intensification of surface gasification processes, e.g. with participation of redox sites in the support, interaction with promoters $(\mathrm{K}, \mathrm{Ce})$, changing of electronic properties of metal particles and their shape or enhancing surface oxygen mobility. Similar effects can be obtained by the decrease of metal crystallite size, which result in the increase of metal-support border-line, and increase of the rate of surface reactions with participation of hydroxyl groups or redox sites on the support. The decrease of the rate of filamentous carbon deposit formation by the decrease of nickel crystallite size in ESR reaction in the $\mathrm{Ni} / \mathrm{CeO}_{2}$ catalysts has been recently evidenced by Slowik et al. [73]. Fig. 2e reveals dominant contribution of very small nickel crystallites in the $\mathrm{Ni}_{10} \mathrm{SiBEA}$ catalyst. Whereas $\mathrm{Ni}_{10} \mathrm{HAlBEA}$ catalyst contains both small and large nickel crystallites. The crystallite size distribution is very broad. Hence the observed differences of the nature of carbon deposits in the catalysts after ESR reaction (Fig. 13 and 15) can be explained by the participation of both small and large crystallites in the formation of carbon deposits. Moreover, due to the different size of nickel crystallites and different rate of carbon deposit formation, such process may lead to the development of carbon filaments of different diameter and graphitization degree. 
Another reason of improved resistance of $\mathrm{Ni}_{10} \mathrm{SiBEA}$ catalyst towards coking is lower acidity of the SiBEA support. TPD $\mathrm{NH}_{3}$, DRIFTS and pyridine FTIR studies indicated the presence of the large number of Brønsted acid sites on the HAlBEA support (Figs. 6-9, Table 3). It seem very probable that high initial activity and selectivity of $\mathrm{Ni}_{10} \mathrm{HAlBEA}$ catalyst can be ascribed to the enhanced adsorption of ethanol and water on the acid sites on the support, fast migration of surface species to the metal-support border line and $\mathrm{C}-\mathrm{C}$ bond cleavages on nickel crystallites. Due the presence of Brønsted acid sites on the HAlBEA support, ethanol can be easily decomposed to ethylene, then partially converted to higher hydrocarbons and carbon deposit. Hence the role of hydroxyl groups in activation of water and ethanol molecules in ESR reaction can be partially suppressed with the time-on-stream. In the subsequent stages of $\mathrm{Ni}_{10} \mathrm{HAlBEA}$ catalyst operation, the reaction may exclusively occur on the surface of nickel crystallites, located on the top of carbon filament or partially covered by carbon deposit, as well as independently on the zeolite acid sites, leading to the gradual transformation of both forms of carbon deposits.

In the case of $\mathrm{Ni}_{10} \mathrm{SiBEA}$ catalyst, which showed very low acidity, the processes of the formation of heavier hydrocarbons and their transformation to coke on the support are less pronounced. Surface species formed after adsorption of ethanol or water, due to the presence of small nickel crystallites, can easily diffuse and participate in surface reactions occurred on nickel crystallites or close to the interfacial region metal-support, preventing fast transformation of filaments or surface carbonaceous films towards encapsulating carbons.

\section{Conclusions}

The effects of dealumination of BEA zeolite on the properties of nickel catalyst and its performance in the steam reforming of bioethanol were studied. It was indicated that dealumination of BEA zeolite led to the formation of specific sites in the zeolite framework, 
which facilitated particular adsorption of nickel precursors, hindering agglomeration of nickel ionic species during calcination into the large $\mathrm{NiO}$ crystalline species and subsequent formation of metallic nickel crystallites during reduction.

Nickel-SiBEA catalysts obtained by the application of dealuminated BEA zeolite showed higher active surface area in comparison to that prepared using unmodified BEA support. It was observed that dealumination led to the slight decrease of crystallinity and simultaneously pronounced decrease of acidity of zeolite.

Pure zeolites and obtained nickel catalysts showed complete conversion of ethanol during long operation time of more than $20 \mathrm{~h}$. However, the main reaction product of the reaction performed in the presence of zeolite supports was ethylene. Small amounts of propane were initially formed in the presence of HAlBEA zeolite. The decrease of selectivity to propene was ascribed to the partial deactivation of zeolites by carbon deposit formation. Nickel modified HAlBEA zeolite showed higher initial selectivity to hydrogen and carbon dioxide than the nickel catalyst with dealuminated support (SiBEA), however the selectivity decreased during the first 5 hours with the time-on-stream, and the reaction led to the formation of large amounts of ethylene. In contrast, nickel catalyst with less acidic support showed stable selectivity to $\mathrm{CO}_{2}$ on the level of $60 \%$ for long time-on-stream.

Microscopic and Raman spectroscopy studies of the samples after SRE reaction evidenced different forms of deposits on the surface of catalysts. Large amounts filamentous carbon and less ordered carbon deposit forms were identified in the catalysts with unmodified BEA zeolite support.

The presence of highly dispersed nickel nanoparticles, and simultaneously the decreased acidity of the support as shown for SiBEA support, facilitated high conversion of ethanol and water, as well as good selectivity to $\mathrm{H}_{2}$ and $\mathrm{CO}_{2}$ for long operation time. 


\section{Acknowledgements}

The research was carried out with the equipment purchased thanks to the financial support of the European Regional Development Fund in the framework of the Innovative Economy Operational Programme (Project No. POIG.02.01.00-06-024/09 Centre for Functional Nanomaterials).

\section{References}

[1] M. Balat, H. Balat, Recent trends in global production and utilization of bio-ethanol fuel, Appl. Energy 86 (2009) 2273-2282.

[2] A. Demirbaş, Bioethanol from cellulosic materials: a renewable motor fuel from biomass, Energ. Source. 27 (2005) 327-337.

[3] N. Sarkar, S.K. Ghosh, S. Bannerjee, K. Aikat, Bioethanol production from agricultural wastes: An overview, Renew. Energ. 37 (2012) 19-27.

[4] L. Viikari, J. Vehmaanperä, A. Koivula, Lignocellulosic ethanol: from science to industry, Biomass. Bioenerg. 46 (2012) 13-24.

[5] M. Ni, D.Y.C. Leung, M.K.H. Leung, A review on reforming bio-ethanol for hydrogen production, Int. J. Hydrogen Ener. 32 (2007) 3238-3247.

[6] J.H. Wang, C.S. Lee, M.C. Lin, Mechanism of ethanol reforming: theoretical foundations, J. Phys. Chem. C 113 (2009) 6681-6688.

[7] L.V. Mattos, G. Jacobs, B.H. Davis, F.B. Noronha, Production of hydrogen from ethanol: review of reaction mechanism and catalyst deactivation, Chem. Rev. 212 (2012) 40944123. 
[8] J.L. Contreras, J. Salmones, J.A. Colí-Luna, L. Nuño, B. Quintana, I. Córdova , B. Zeifert, C. Tapia , G.A. Fuentes , Catalysts for $\mathrm{H}_{2}$ production using the ethanol steam reforming (a review), Int. J. Hydrogen Ener. 39 (2014) 18835-18853.

[9] T. Hou, S. Zhang, Y. Chen, D. Wang, W. Cai, Hydrogen production from ethanol reforming: Catalysts and reaction mechanism, Renew. Sust. Energ. Rev. 44 (2015) 132 148.

[10] D. Zanchet, J. Batista O. Santos, S. Damyanova, J.M.R. Gallo, J.M.C. Bueno, Toward understanding metal-catalyzed ethanol reforming, ACS Catal. 5 (2015) 3841-3863.

[11] Y.C. Sharma, A. Kumar, Ram Prasad, S.N. Upadhyay, Ethanol steam reforming for hydrogen production: Latest and effective catalyst modification strategies to minimize carbonaceous deactivation, Renew. Sust. Ener. Rev. 74 (2017) 89-103.

[12] I. Takahara, M. Saito, M. Inaba, K. Murata, Dehydration of ethanol into ethylene over solid acid catalysts, Catal. Lett. 105 (2005) 249-252.

[13] C. Montero, A. Ochoa, P. Castaño, J. Bilbao, A.G. Gayubo, Monitoring $\mathrm{Ni}^{0}$ and coke evolution during the deactivation of a $\mathrm{Ni} / \mathrm{La}_{2} \mathrm{O}_{3}-\alpha-\mathrm{Al}_{2} \mathrm{O}_{3}$ catalyst in ethanol steam reforming in a fluidized bed, J. Catal. 331 (2015) 181-192.

[14] S.M. de Lima, A.M. da Silva, L.O.O. da Costa, U.M. Graham, G. Jacobs, B.H. Davis, L.V. Mattos, F.B. Noronha, Study of catalyst deactivation and reaction mechanism of steam reforming, partial oxidation, and oxidative steam reforming of ethanol over $\mathrm{Co} / \mathrm{CeO}_{2}$ catalyst, J. Catal. 268 (2009) 268-281.

[15] V.K. Díez, C. R. Apesteguía, J.I. Di Cosimo, Effects of the acid-base properties of Mg$\mathrm{Al}$ mixed oxides on the catalyst deactivation during aldol condenstation reaction, Lat. Am. Appl. Res. 33 (2003) 79-86. 
[16] I. Rossetti, M. Compagnoni, E. Finocchio, G. Ramis, A. Di Michele, A. Zucchini, S. Dzwigaj, Syngas production via steam reforming of bioethanol over NiBEA catalysts: A BTL strategy, Int. J. Hydrogen Ener. 41 (2016) 16878-16889

[17] J.F. Da Costa-Serra, M.T. Navarro, F. Rey, A. Chica, Bioethanol steam reforming on Nibased modified mordenite. Effect of mesoporosity, acid sites and alkaline metals, Int. J. Hydrogen Ener. (2012) 7101-7108.

[18] L. Lang, S. Zhao, X. Yin, W. Yang, C. Wu, Catalytic activities of K-modified zeolite ZSM-5 supported rhodium catalysts in low-temperature steam reforming of bioethanol, Int. J. Hydrogen Ener. 40 (2015) 9924-9934.

[19] Z. Zheng, C. Sun, R. Dai, S. Wang, X. Wu, X. An, Z. Wu, X. Xie, Ethanol steam reforming on Ni-based catalysts: effect of $\mathrm{Cu}$ and $\mathrm{Fe}$ addition on the catalytic activity and resistance to deactivation, Energy Fuels 31 (2017) 3091-3100.

[20] Z. Zheng, C. Sun, R. Dai, S. Wang, X. Wu, X. An, X. Xie, Organotemplate-free synthesis of hollow Beta zeolite supported Pt-based catalysts for low-temperature ethanol steam reforming, Catal. Sci. Technol. 6 (2016) 6472-6475.

[21] Z. Zheng, D. Yang, T. Li, X. Yin, S. Wang, X. Wu, X. An, X. Xie, A novel BEA-type zeolite core-shell multiple catalyst for hydrogen-rich gas production from ethanol steam reforming, Catal. Sci. Technol., 6 (2016) 5427-5439.

[22] H. Inokawa, S. Nishimoto, Y. Kameshima, M. Miyake, Promotion of $\mathrm{H}_{2}$ production from ethanol steam reforming by zeolite basicity, Int. J. Hydrogen Ener. 36 (2011) 1519515202.

[23] F.C.Campos-Skrobot, R.C.P. Rizzo-Domingues, N.R.C. Fernandes-Machado, M.P. Cantão, Novel zeolite-supported rhodium catalysts for ethanol steam reforming, J. Power Sources 183 (2008) 713-716. 
[24]-R.M. Barrer, M.B. Makki, Molecular sieve sorbents from clinoptilolite, Can. J. Chem. $42(1964) 1481-1487$.

[25]-SH.K. Beyer, Dealumination Techniques for Zeolites, Molecular Sieves, Springer-Verlag Berlin Heidelberg 2002.

[26]-M. Auerbach, K.A. Carrado, P.K. Dutta, Handbook of Zeolite Science and Technology, Marcel Dekker Inc., New York 2003.

[27] R. Hajjar, Y. Millot, P.P. Man, M. Che, S. Dzwigaj, Two kinds of framework Al sites studied in BEA zeolite by X-ray diffraction, Fourier Transform Infrared Spectroscopy, NMR Techniques, and V Probe, J. Phys. Chem. C 112 (2008) 20167-20175.

[28] A. Chica, S. Sayas, Effective and stable bioethanol steam reforming catalyst based on Ni and Co supported on all-silica delaminated ITQ-2 zeolite, Catal. Today 146 (2009) 37-43.

[29] J.F. Da Costa-Serra, A. Chica, Bioethanol steam reforming on Co/ITQ-18 catalyst: Effect of the crystalline structure of the delaminated zeolite ITQ-18, Int. J. Hydrogen Ener. 36 (2011) 3862-3869.

[30] K.A. Chalupka, W.K. Jozwiak, J. Rynkowski, W. Maniukiewicz, S. Casale, S. Dzwigaj, Partial oxidation of methane on NixAlBEA and NixSiBEA zeolite catalysts: Remarkable effect of preparation procedure and Ni content, Appl. Catal. B 146 (2014) 227-236.

[31] J.B. Condon, Surface Area and Porosity Determinations by Physisorption: Measurements and Theory, Elsevier B.V., Amsterdam, 2006, pp. 1-27.

[32] M. Jaroniec, M. Kruk, J.P. Olivier, Standard nitrogen adsorption data for characterization of nanoporous silicas, Langmuir 15 (1999) 5410-5413.

[33] C.A. Emeis, Determination of integrated molar extinction coefficients for infrared absorption bands of pyridine adsorbed on solid acid catalysts, J. Catal. 141 (1993) 347 354.

[34] http://europe.iza-structure.org/IZA-SC/framework.php?STC=BEA 
[35] F. Bentaleb, M. Che, A.C. Dubreuil, C. Thomazeau, E. Marceau, Influence of organic additives on the properties of impregnation solutions and on nickel oxide particle size for $\mathrm{Ni} / \mathrm{Al}_{2} \mathrm{O}_{3}$ catalysts, Catal. Today 235 (2014) 250-255.

[36] F. Vratny, Infrared Spectra of Metal Nitrates, Appl. Spectrosc. 13 (1959) 59-70.

[37] V.L. Zholobenko, S.H. Holmes, C.S. Cundy, J. Dwyer, Synthesis of MCM-41 materials: an in situ FTIR study, Micropor. Mesopor. Mater. 11 (1997) 83-86.

[38] J. Ryczkowski, J. Goworek, W. Gac, S. Pasieczna, T. Borowiecki, Temperature removal of templating agent from MCM-41 silica materials, Thermochim. Acta 432 (2005) 2-8.

[39] R. Baran, Y. Millot, T. Onfroy, J.-M. Krafft, S. Dzwigaj, Influence of the nitric acid treatment on $\mathrm{Al}$ removal, framework composition and acidity of BEA zeolite investigated by XRD, FTIR and NMR, Micropor. Mesopor. Mater. 163 (2012) 122 -130.

[40] M. Tadic, D. Nikolic, M. Panjan and G. R. Blake, Magnetic properties of NiO (nickel oxide) nanoparticles: Blocking temperature and Neel temperature, J. Alloys Compd. 647 (2015) 1061-1068.

[41] N. Rinaldi-Montes, P. Gorria, D. Martínez-Blanco, A. B. Fuertes, I. Puente-Orench, L. Olivi, J.A. Blanco, Size effects on the Néel temperature of antiferromagnetic NiO nanoparticles, AIP Adv. 6 (2016) 056104-1 - 056104-5

[42] V. I. Bakhmutov, Strategies for solid-state NMR studies of materials: from diamagnetic to paramagnetic porous solids, Chem. Rev. 111 (2011) 530-562.

[43] G. Pintacuda, G. Kervern, Paramagnetic solid-state magic-angle spinning NMR spectroscopy, Top. Curr. Chem. 335 (2013) 157-200.

[44] S. Dzwigaj, Y. Millot, C. Méthivier, M. Che, Incorporation of $\mathrm{Nb}(\mathrm{V})$ into BEA zeolite investigated by XRD, NMR, IR, DR UV-vis, and XPS, Micropor. Mesopor. Mater. 130 (2010) 162-166. 
[45] N. O. Popovych, P. I. Kyriienko, Y. Millot, L. Valentin, J. Gurgul, R. P. Socha, J. Żukrowski, S. O. Soloviev, S. Dzwigaj, Sn-BEA zeolites prepared by two-step postsynthesis method: Physicochemical properties and catalytic activity in processes based on MPV reduction, Micropor. Mesopor. Mater. 268 (2018) 178-188.

[46] G.L. Woolery, L.B. Alemany, R.M. Dessau, A.W. Chester, Spectroscopic evidence for the presence of internal silanols in highly siliceous ZSM-5, Zeolites 6 (1986) 14-16.

[47] L.W. Beck, J.F. Haw, J.L. White, ${ }^{1} \mathrm{H}\left\{{ }^{27} \mathrm{Al}\right\}$ Double-resonance experiments in solids: An unexpected observation in the ${ }^{1} \mathrm{H}$ MAS spectrum of zeolite HZSM-5, J. Am. Chem. Soc. 116 (1994) 9657-9661.

[48] P.I. Kyriienko, O. V Larina, N.O. Popovych, S.O. Soloviev, Y. Millot, S. Dzwigaj, Effect of the niobium state on the properties of NbSiBEA as bifunctional catalysts for gasand liquid-phase tandem processes, J. Mol. Catal. A. Chem. 424 (2016) 27-36.

[49] W. Gac, Acid-base properties of Ni-MgO- $\mathrm{Al}_{2} \mathrm{O}_{3}$ materials, Appl. Surf. Sci., 257 (2011) 2875-2880.

[50] S. Dzwigaj, M. Che, Incorporation of Co(II) in dealuminated BEA zeolite at lattice tetrahedral sites evidenced by XRD, FTIR, diffuse reflectance UV-Vis, EPR, and TPR, J. Phys. Chem. B 110 (2006) 12490-12493.

[51]E. Bourgeat-Lami, F. Fajula, D. Anglerat, T. des Courieres, Single step dealumination of zeolite beta precursors for the preparation of hydrophobic adsorbents, Micropor. Mater. 12 (1993) 237-245.

[52] A. Janin, M. Maache, J.C. Lavalley, J.F. Joly, F. Raatz, N. Szydlowski, FT i.r. study of the silanol groups in dealuminated HY zeolites: Nature of the extraframework debris, Zeolites 11 (1991) 391-396.

[53] S. Dzwigaj, P. Massiani, A. Davidson, M. Che, Role of silanol groups in the incorporation of V in $\beta$ zeolite, J. Mol. Catal. A 155 (2000) 169-182. 
[54] R. Baran, Y. Millot, T. Onfroy, F. Averseng, J.-M. Krafft, S. Dzwigaj, Influence of the preparation procedure on the nature and environment of vanadium in VSiBEA zeolite: XRD, DR UV-vis, NMR, EPR and TPR studies, Micropor. Mesopor. Mater. 161 (2012) 179-186.

[55] A. Penkova, S. Dzwigaj, R. Kefirov, K. Hadjiivanov, M. Che, Effect of the preparation method on the state of nickel ions in BEA zeolites. A stu dy by Fourier transform infrared spectroscopy of adsorbed $\mathrm{CO}$ and NO, temperature-programmed reduction, and X-ray diffraction, J. Phys. Chem. C 111 (2007) 8623-8631.

[56] M. Trejda, M. Ziolek, Y. Millot, K. Chalupka, M. Che, S. Dzwigaj, Methanol oxidation on VSiBEA zeolites: Influence of V content on the catalytic properties, J. Catal. 281 (2011) 169-176.

[57] G.M. Robb, W. Zhang, P.G. Smirniotis, Acidity of dealuminated $\beta$-zeolites via coupled $\mathrm{nh}_{3}$-stepwise temperature programmed desorption (STPD) and FT-IR spectroscopy, Micropor. Mesopor. Mater. 20 (1998) 307-316.

[58] S. Dzwigaj, M. Matsuoka, Masakazu Anpo, M. Che, Effect of metal content and calcination-hydration on the environment of $\mathrm{V}$ in zeolites prepared by impregnation of SiBEA with $\mathrm{V}^{\mathrm{IV}} \mathrm{OSO}_{4}$ solution, Micropor. Mesopor. Mater. 93 (2006) 248-253.

[59] C. Louis, Z.X. Cheng, M. Che, Characterization of $\mathrm{Ni} / \mathrm{SiO}_{2}$ catalysts during impregnation and further thermal activation treatment leading to metal particles, J. Phys. Chem. 97 (1993) 5703-5712.

[60] N. W. Hurst, S. J. Gentry, A. Jones, B.D. McNicol, Temperature programmed reduction, Catal. Rev. Sci. Eng. 24 (1982) 233-309.

[61] C. H. Bartholomew, Hydrogen adsorption on supported cobalt, iron, and nickel, Catal. Letters 7 (1990) 27-52. 
[62] L. Znak, J. Zieliński, Effects of support on hydrogen adsorption/desorption on nickel, Appl. Catal. A 334 (2008) 268-276.

[63] H. Xin, X. Li, Y. Fang, X. Yi, W. Hu, Y. Chu, F. Zhang, A. Zheng, H. Zhang, X. Li, Catalytic dehydration of ethanol over post-treated ZSM-5 zeolites, J. Catal. 312 (2014) 204-215.

[64] K. Ramasamy, Y. Wang, Ethanol conversion to hydrocarbons on HZSM-5: Effect of reaction conditions and Si/Al ratio on the product distributions, Catal. Today 237 (2014) 89-99.

[65] J. Sun, Y. Wang, Recent advances in catalytic conversion of ethanol to chemicals, ACS Catal. 4 (2014) 1078-1090.

[66] D. Däumer, M. Seifert, W. Reschetilowski, Durability improvements of H-ZSM-5 zeolite for ethanol conversion after treatment with chelating agents, Micropor. Mesopor. Mater. 219 (2016) 66-76.

[67] A. Galadima, O. Muraza, Zeolite catalysts in upgrading of bioethanol to fuels range hydrocarbons: A review, J. Ind. Eng. Chem. 31 (2015) 1-14.

[68] S. Sujeerakulkai, S. Jitkarnka, Bio-based hydrocarbons and oxygenates from catalytic bio-ethanol dehydration: comparison between gallium and germanium oxides as promoters on HBeta zeolites with various silica to alumina ratios, J. Clean. Prod. 111 (2016) 51-61.

[69] J. Schulz, F. Bandermann, Conversion of ethanol over zeolite H-ZSM-5, Chem. Eng. Technol. 17 (1994) 179-186.

[70] I. Rossetti, M. Compagnoni, G. De Guido, L. A. Pellegrini, G. Ramis, S. Dzwigaj, Ethylene production from diluted bioethanol solutions, Can. J. Chem. Eng. 95 (2017) $1752-1759$. 
[71] I. Rossetti, M. Compagnoni, E. Finocchio, G. Ramis, A. Di Michele, Y. Millot, S. Dzwigaj, Ethylene production via catalytic dehydration of diluted bioethanol: A step towards an integrated biorefinery, Appl. Catal. B 210 (2017) 407-420.

[72] Ch. Zhang, S. Li, G. Wu, J. Gong, Synthesis of stable Ni-CeO 2 catalysts via ball-milling for ethanol steam reforming, Catal. Today 233 (2014) 53-60.

[73] G. Slowik, M. Greluk, M. Rotko, A. Machocki, Evolution of the structure of unpromoted and potassium-promoted ceria supported nickel catalysts in the steam reforming of ethanol, Appl. Catal. B 221 (2018) 490-509.

[74] R. Van Hardeveld, F. Hartog, The statistics of surface atoms and surface sites on metal crystals, Surf. Sci, 15 (1969) 189-230.

[75] F. Baletto, R. Ferrando, Structural properties of nanoclusters: Energetic, thermodynamic, and kinetic effects, Rev. Mod. Phys. 77 (2005) 371-423.

[76] M.C. Sánchez-Sánchez, R.M. Navarro*, J.L.G. Fierro, Ethanol steam reforming over $\mathrm{Ni} / \mathrm{M}_{\mathrm{x}} \mathrm{O}_{\mathrm{y}}-\mathrm{Al}_{2} \mathrm{O}_{3}(\mathrm{M}=\mathrm{Ce}, \mathrm{La}, \mathrm{Zr}$ and $\mathrm{Mg})$ catalysts: Influence of support on the hydrogen production, Int. J. Hydrogen Ener. 32 (2007) 1462-1471.

[77] A. Denis, W. Grzegorczyk, W. Gac, A. Machocki, Steam reforming of ethanol over $\mathrm{Ni} /$ support catalysts for generation of hydrogen for fuel cell applications, Catal. Today 137 (2008) 453-459.

[78] P. Castaño, G. Elordi, M. Olazar, A.T. Aguayo, B. Pawelec, J. Bilbao, Insights into the coke deposited on HZSM-5, H and HY zeolites during the cracking of polyethylene, Appl. Catal. B 104 (2011) 91-100.

[79] C. Li, P.C. Stair, Ultraviolet Raman spectroscopy characterization of coke formation in zeolites, Catal. Today 33 (1997) 353-360. 
[80] J. Li, G. Xiong, Z. Feng, Z. Liu, Q. Xin, C. Li, Coke formation during the methanol conversion to olefins in zeolites studied by UV Raman spectroscopy, Micropor. Mesopor. Mater. 39 (2000) 275-280.

[81] A. C. Ferrari, J. Robertson, Raman spectroscopy of amorphous, nanostructured, diamond-like carbon, and nanodiamond, Phil. Trans. R. Soc. Lond. A 362 (2004) 24772512.

[82] Y. Wang, D.C. Alsmeyer, R.L. McCreery, Raman spectroscopy of carbon materials: structural basis of observed spectra, Chem. Mater. 2 (1990) 557-563.

[83] J. Schwan, S. Ulrich, V. Batori, H. Ehrhardt, S.R.P. Silva, Raman spectroscopy on amorphous carbon films, J. Appl. Phys. 80 (1996) 440-447.

[84] A. C. Ferrari, J. Robertson, Interpretation of Raman spectra of disordered and amorphous carbon, Phys. Rev. B 61 (2000) 14095-14107.

[85] A. Sadezky, H. Muckenhuber , H. Grothe, R. Niessner, U. Pöschl, Raman microspectroscopy of soot and related carbonaceous materials: Spectral analysis and structural information, Carbon 43 (2005) 1731-1742.

[86] M.D. Argyle, C.H. Bartholomew, Heterogeneous catalyst deactivation and regeneration: A review, Catalysts 5 (2015) 145-269. 
Table 1. Specific surface area $\left(S_{B E T}\right)$, total pore volume $\left(V_{p}\right)$, mean pore diameter $\left(D_{p}\right)$ of the samples, mean crystallite size of $\mathrm{NiO}\left(d_{N i O}\right)$.

\begin{tabular}{cccccc}
\hline Sample & $\begin{array}{c}\text { Ni content } \\
(\text { wt. \% })\end{array}$ & $\begin{array}{c}S_{B E T} \\
\left(\mathrm{~m}^{2} / \mathrm{g}\right)\end{array}$ & $\begin{array}{c}V_{p} \\
\left(\mathrm{~cm}^{3} / \mathrm{g}\right)\end{array}$ & $\begin{array}{c}D_{p} \\
(\mathrm{~nm})\end{array}$ & $\begin{array}{c}d_{\text {NiO }} \\
(\mathrm{nm})\end{array}$ \\
\hline HAlBEA & - & 540.5 & 0.53 & 15.1 & - \\
SiBEA & - & 421.4 & 0.51 & 18.0 & - \\
$\mathrm{Ni}_{10} \mathrm{HAlBEA}$ & $9.86 \pm 0.30$ & 481.7 & 0.48 & 15.5 & 22.3 \\
$\mathrm{Ni}_{10} \mathrm{SiBEA}$ & $9.57 \pm 0.30$ & 406.8 & 0.42 & 16.2 & 4.1 \\
\hline
\end{tabular}


Table 2. Mean nickel crystallite size determined from XRD and TEM studies, and active surface area of catalysts determined from $\mathrm{H}_{2}$ TPD.

\begin{tabular}{cccc}
\hline Sample & $\begin{array}{c}d_{N i}^{X R D} \\
(\mathrm{~nm})\end{array}$ & $\begin{array}{c}d_{N i}^{T E M} \\
(\mathrm{~nm})\end{array}$ & $\begin{array}{c}S_{a} \\
\left(\mathrm{~m}^{2} / \mathrm{g}\right)\end{array}$ \\
\hline $\mathrm{Ni}_{10} \mathrm{HAlBEA}$ & 30.2 & 22.5 & 1.43 \\
$\mathrm{Ni}_{10} \mathrm{SiBEA}$ & 4.3 & 7.3 & 6.02 \\
\hline
\end{tabular}


Table 3. The amounts of the Brønsted and Lewis acidic centers in $\mathrm{Ni}_{10} \mathrm{HAlBEA}$, HAlBEA, $\mathrm{Ni}_{10} \mathrm{SiBEA}$ and SiBEA.

\begin{tabular}{ccc}
\hline Sample & $\begin{array}{c}\text { Brønsted acidic centers } \\
\left(\mu \mathrm{mol} \mathrm{g}^{-1}\right)^{a}\end{array}$ & $\begin{array}{c}\text { Lewis acidic centers } \\
\left(\mu \mathrm{mol} \mathrm{g}^{-1}\right)\end{array}$ \\
\hline HAlBEA & 268 & 130 \\
$\mathrm{Ni}_{10}$ HAlBEA & 154 & 227 \\
SiBEA & 3 & 3 \\
$\mathrm{Ni}_{10} \mathrm{SiBEA}$ & 3 & 120 \\
\hline
\end{tabular}

${ }^{a}$ Quantification of number of acidic centers in zeolite was done as reported earlier by Emeis [33]. 


\section{Figure captions}

Figure 1. X-ray diffraction curves of zeolites and nickel catalysts after calcination and reduction at $600{ }^{\circ} \mathrm{C}$ for 2 hours; wide (a) and short (b) range of 2 theta.

Figure 2. a) TEM images of $\mathrm{Ni}_{10} \mathrm{HAlBEA}$ catalyst after reduction, b) STEM images of $\mathrm{Ni}_{10} \mathrm{HAlBEA}$ catalyst after reduction, c) TEM images of $\mathrm{Ni}{ }_{10} \mathrm{SiBEA}$ catalyst after reduction,

d) STEM-EDS images of $\mathrm{Ni}_{10} \mathrm{SiBEA}$ catalyst after reduction, e) nickel crystallite size distribution in catalysts.

Figure 3. Nitrogen adsorption-desorption isotherms on nickel catalysts, solid lines adsorption branch, dashed lines - desorption branch. Inset - pore size distribution calculated from the desorption branch of isotherms.

Figure 4. FTIR-PAS spectra of zeolites and nickel catalysts on the different operation stages after impregnation and drying, calcination and reduction; HAlBEA (a) and SiBEA (b) supported catalysts.

Figure 5. ${ }^{27} \mathrm{Al}$ MAS NMR spectra of HAlBEA, Ni ${ }_{10} \mathrm{HAlBEA}$, SiBEA and $\mathrm{Ni}_{10} \mathrm{SiBEA}$

Figure 6. Temperature-programmed desorption of ammonia from zeolites and nickel catalysts after reduction at $600{ }^{\circ} \mathrm{C}-\mathrm{MS}$ intensities of selected ions.

Figure 7. DRIFTS spectra of $\mathrm{Ni}_{10} \mathrm{HAlBEA}$ (a) and $\mathrm{Ni}_{10} \mathrm{SiBEA}$ (b) catalysts recorded during thermal treatment in $\mathrm{H}_{2}$ from $20^{\circ} \mathrm{C}$ to $600^{\circ} \mathrm{C}$ and subsequent cooling down to $100{ }^{\circ} \mathrm{C}$.

Figure 8. FTIR spectra recorded at room temperature of SiBEA and $\mathrm{V}_{2.0} \operatorname{SiBEA}(\mathrm{I})$ and $\mathrm{V}_{2.0} \mathrm{SiBEA}(\mathrm{II})$ in the vibrational range of $\mathrm{OH}$ group.

Figure 9. FTIR spectra recorded at room temperature of SiBEA and $V_{2.0} \operatorname{SiBEA}(\mathrm{I})$ and $\mathrm{V}_{2.0} \mathrm{SiBEA}(\mathrm{II})$ calcined at $450{ }^{\circ} \mathrm{C}$ for $3 \mathrm{~h}$ in $\mathrm{O}_{2}\left(1.610^{4} \mathrm{~Pa}\right)$ and then outgassed at $300{ }^{\circ} \mathrm{C}\left(10^{-3}\right.$ $\mathrm{Pa}$ ) for $1 \mathrm{~h}$ after adsorption of pyridine (133 $\mathrm{Pa})$ for $1 \mathrm{~h}$ at room temperature and desorption at room temperature (a) and $150{ }^{\circ} \mathrm{C}(\mathrm{b})$ for $1 \mathrm{~h}$. 
Figure 10. Temperature-programmed reduction curves of nickel catalysts.

Figure 11. Temperature-programmed hydrogen desorption curves from nickel catalysts.

Figure 12. The results of ethanol steam reforming performed at $500{ }^{\circ} \mathrm{C}$ for $20 \mathrm{~h}$ tests over bare zeolites and nickel catalysts; conversion of ethanol (Fig. 12a) and water (Fig. 12b), selectivity to hydrogen (Fig. 12c), carbon dioxide (Fig. 12d), carbon monoxide (Fig. 12e), ethylene (Fig. 12f), acetaldehyde (Fig. 12g), methane (Fig. 12h), ethane (Fig. 12i), and propane (Fig. 12j).

Figure 13. Microscopic images of the catalysts after ESR reaction performed at $500{ }^{\circ} \mathrm{C}$ for 20 h; a) $\mathrm{Ni}_{10} \mathrm{HAlBEA}$ - TEM (Fig. 13a) and STEM (Fig. 13b); Ni ${ }_{10} \operatorname{SiBEA}$ - TEM (Fig. 13c) and STEM (Fig. 13d).

Figure 14. FTIR-PAS studies of the zeolites and nickel catalysts after ESR reaction.

Figure 15. Raman spectra of zeolites and nickel catalysts after ESR reaction. 


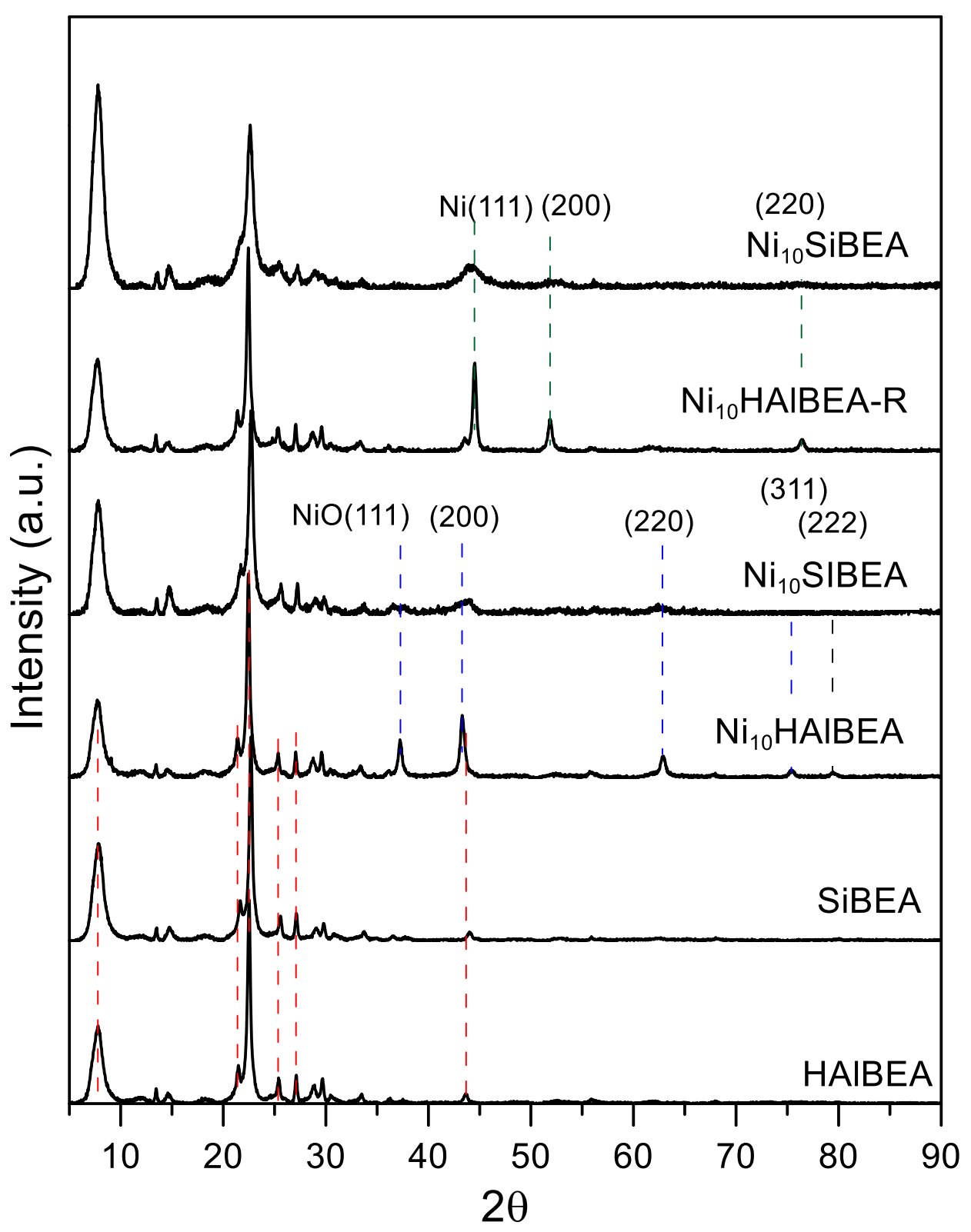

Fig. 1a. 


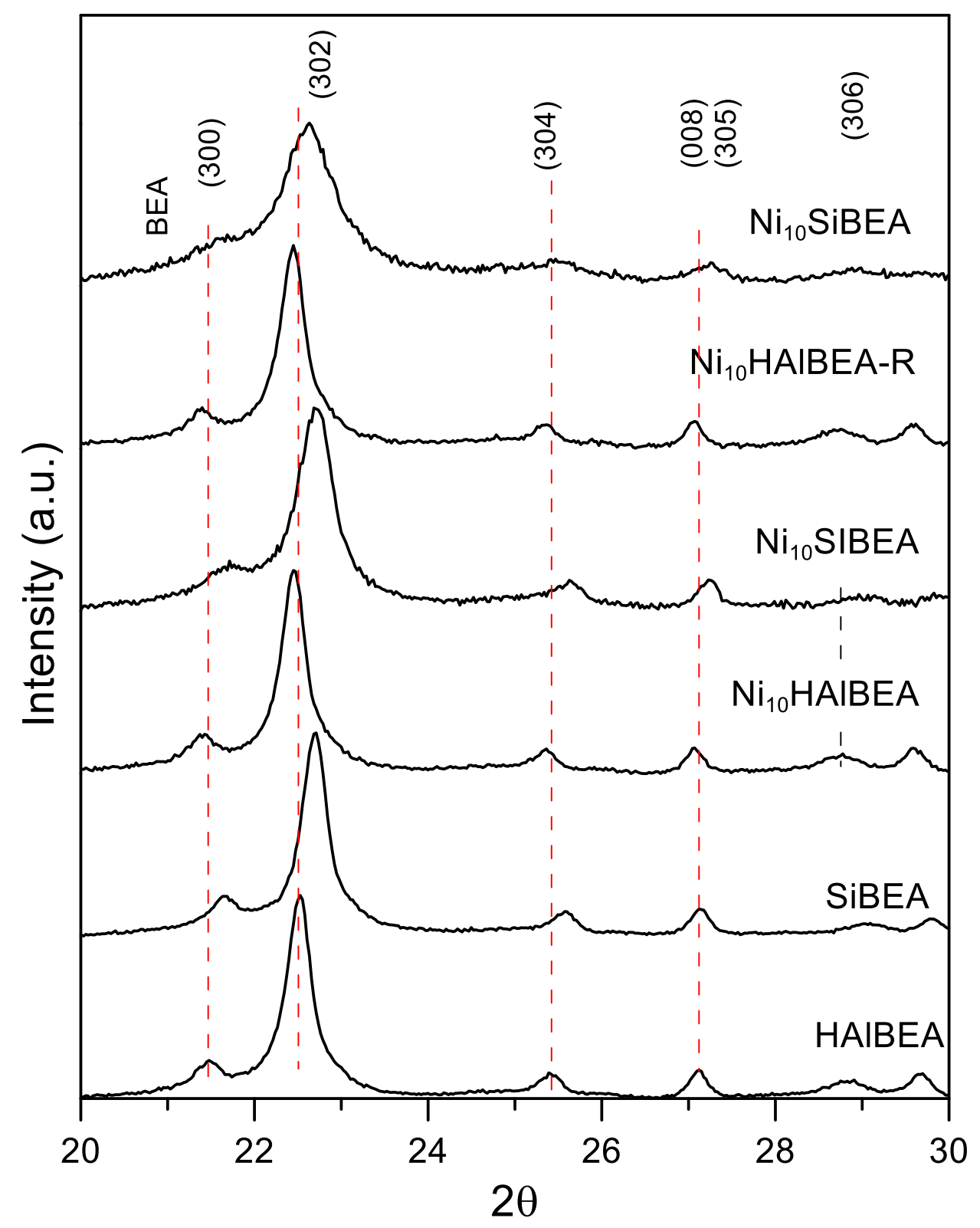

Fig. $1 b$. 


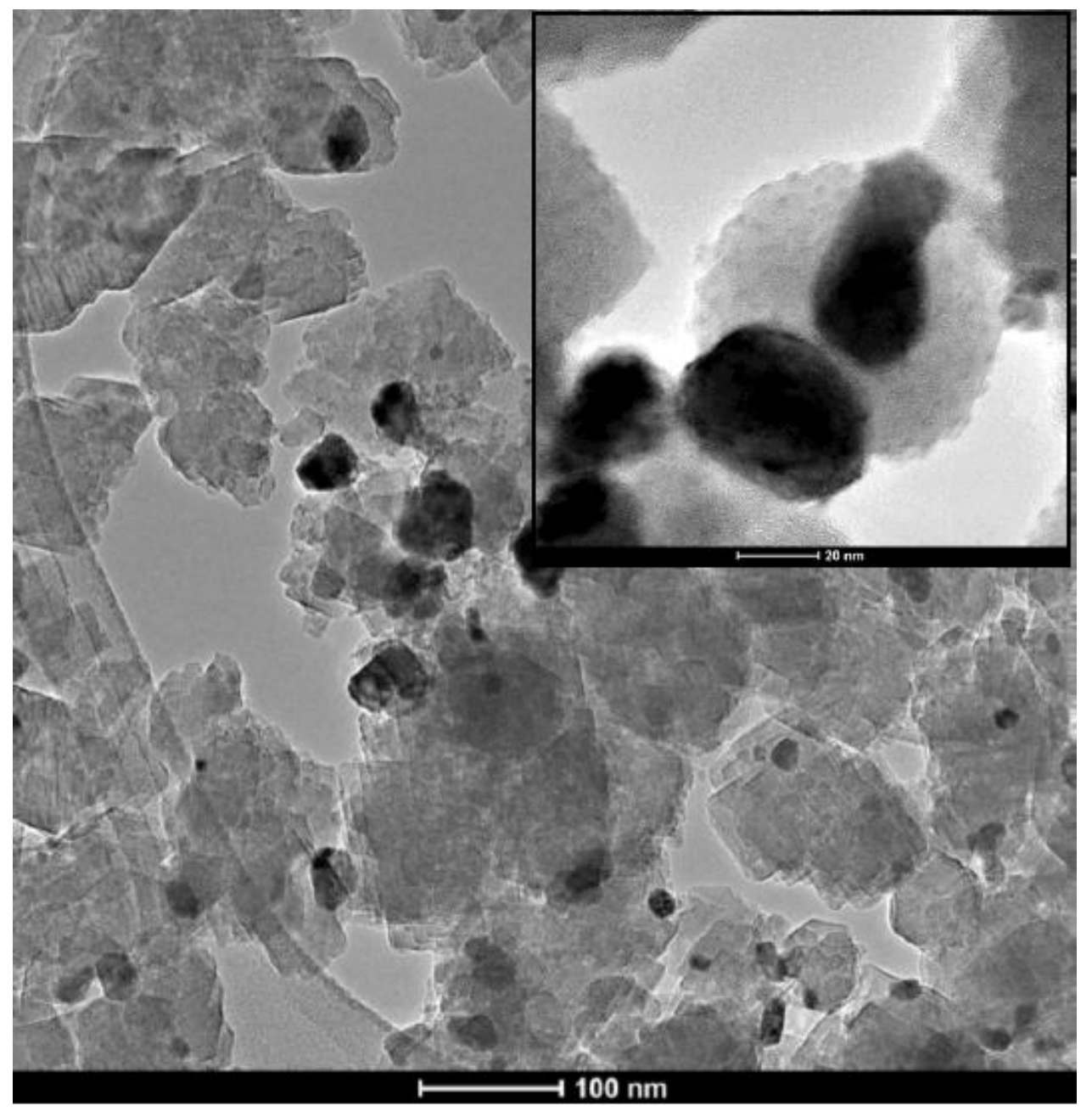

Fig. 2a. 


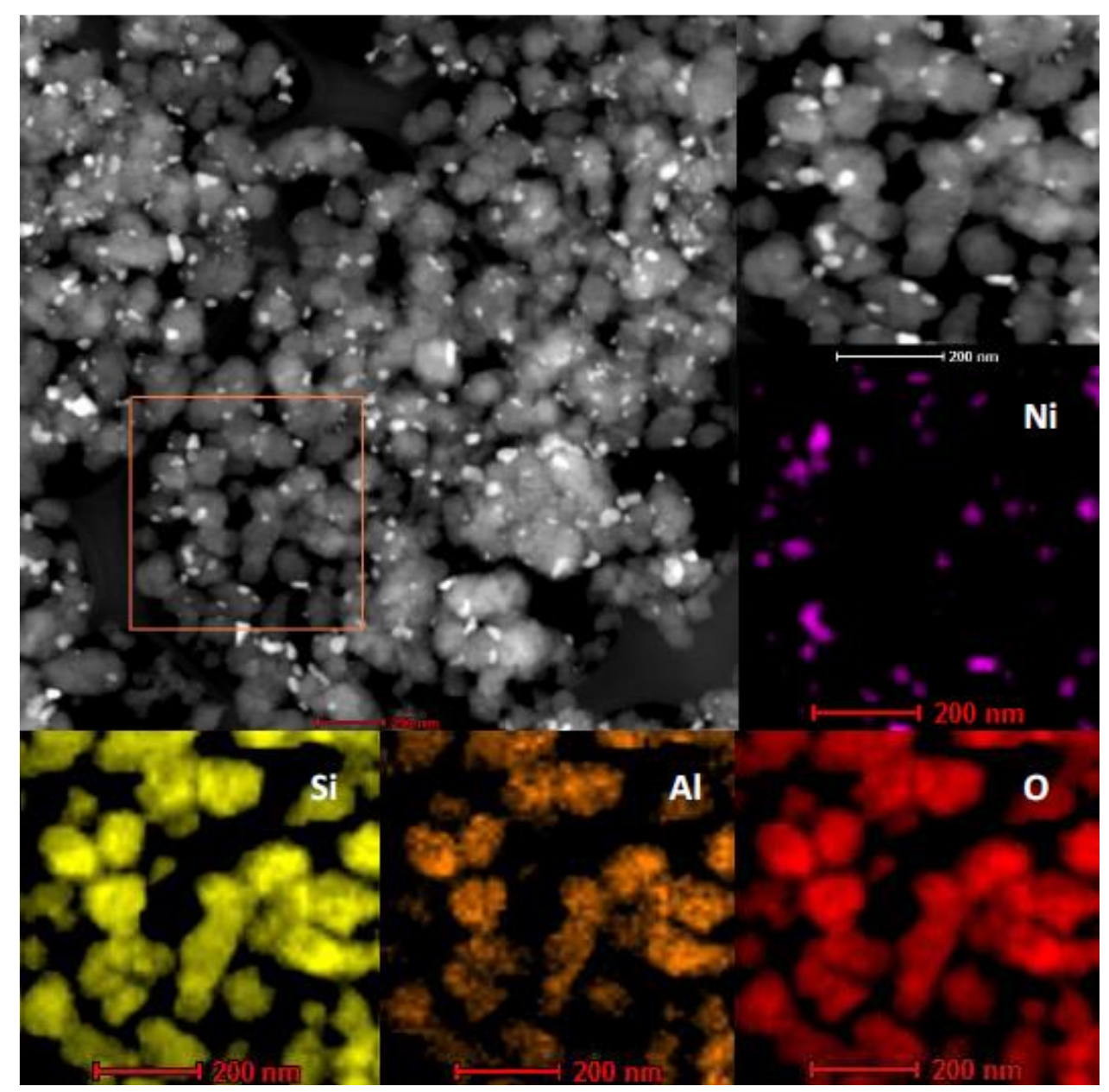

Fig. 2b. 


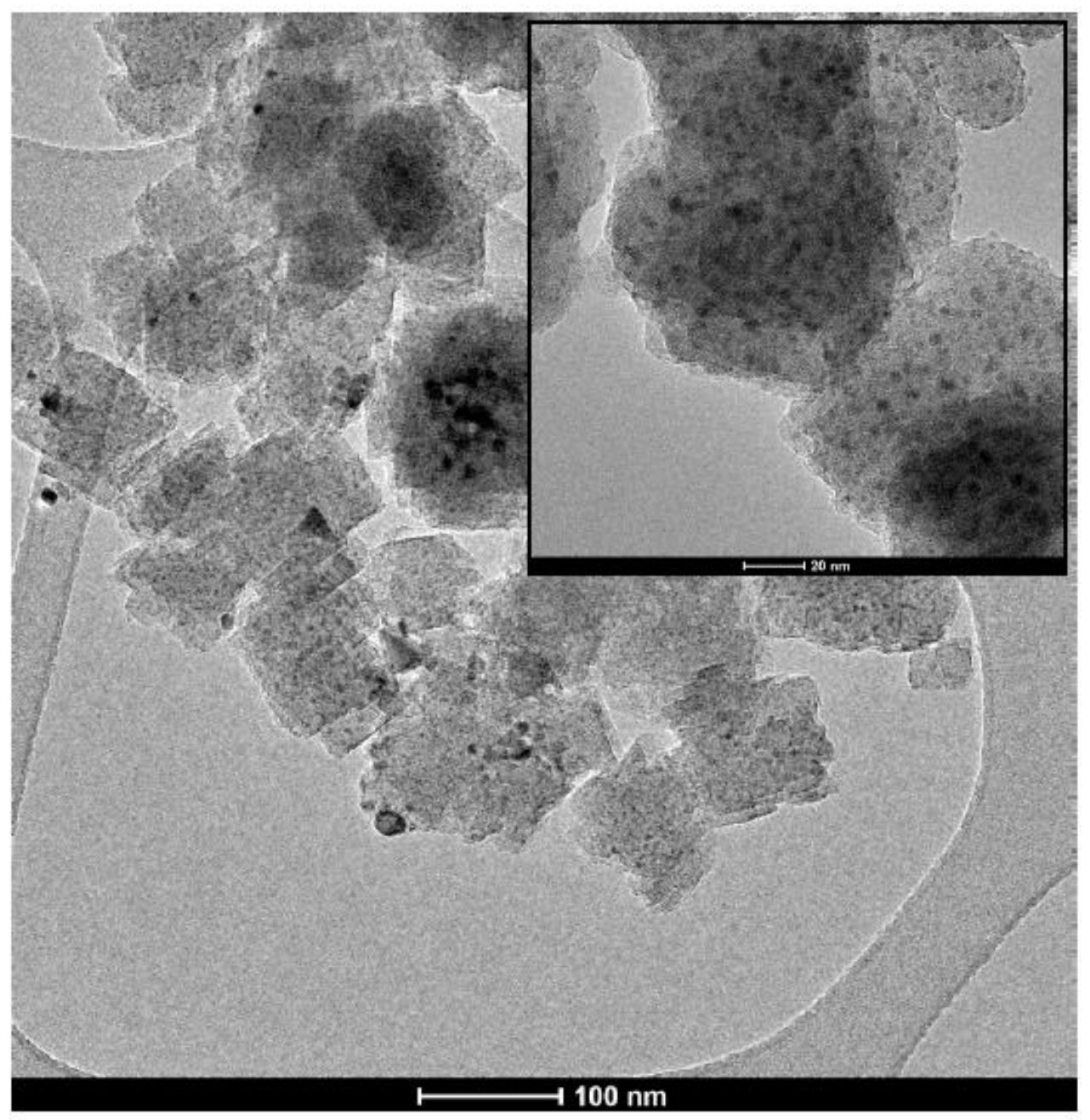

Fig. 2c. 


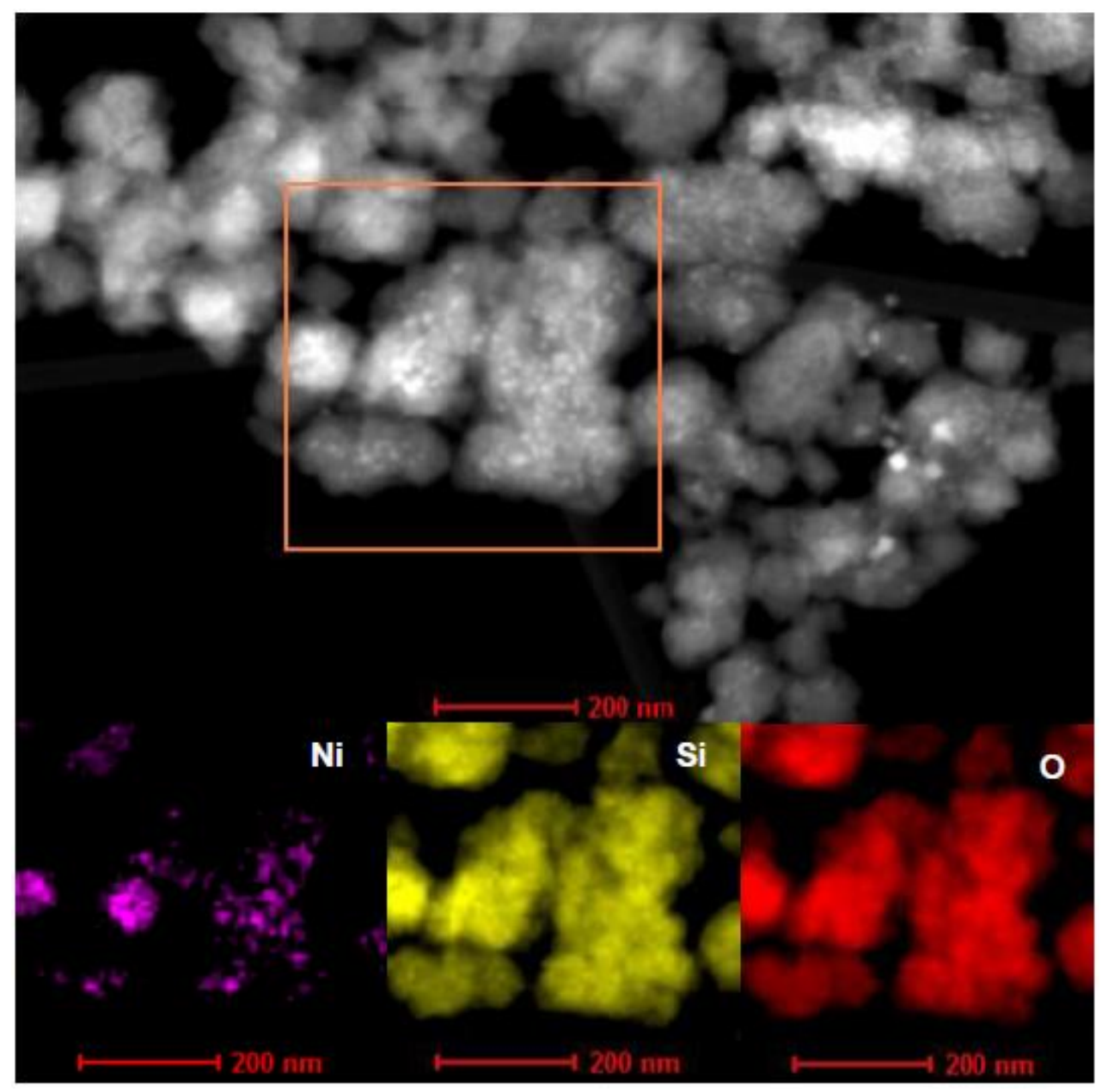

Fig. 2d. 


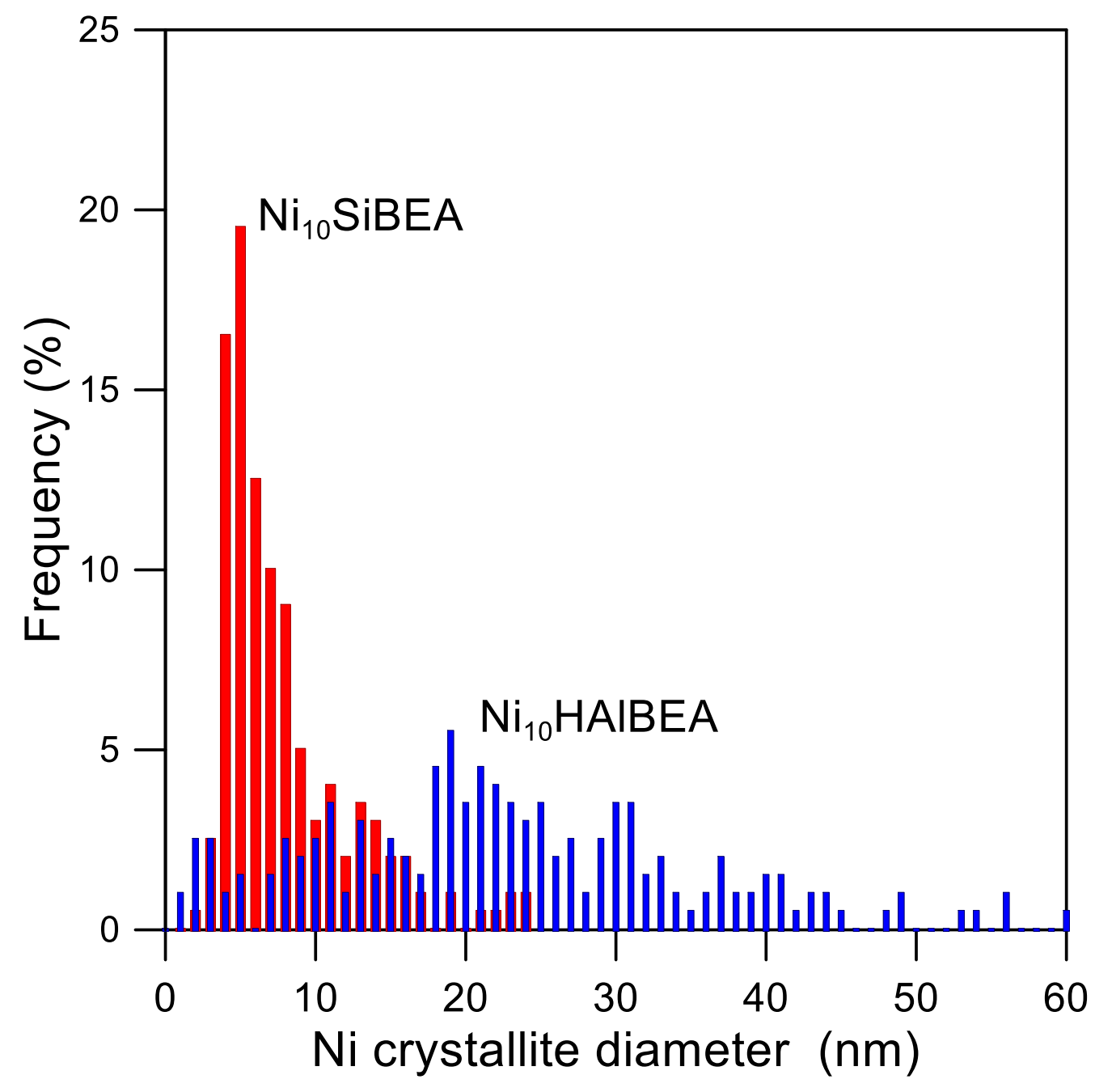

Fig. 2e. 


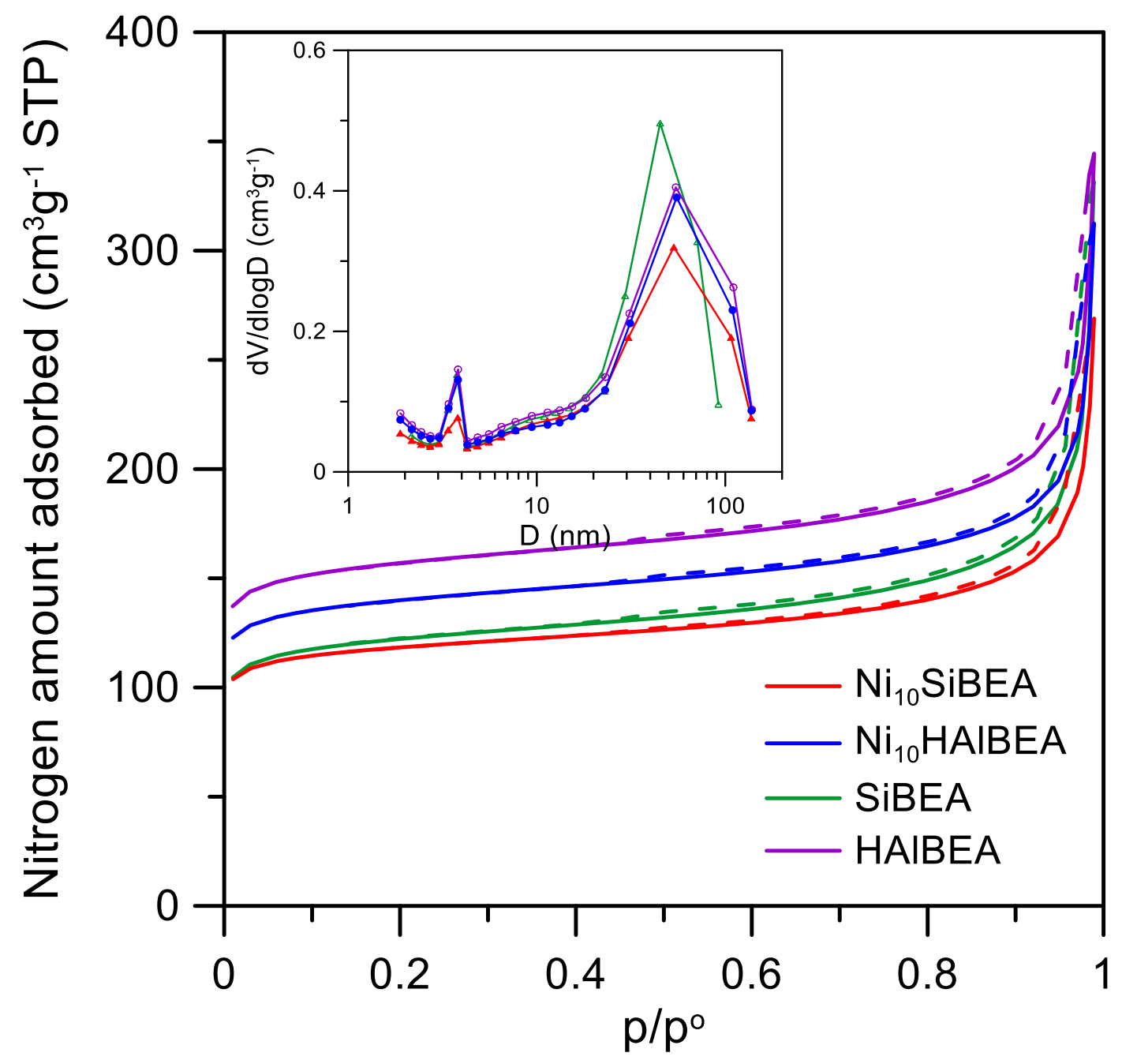

Fig. 3. 


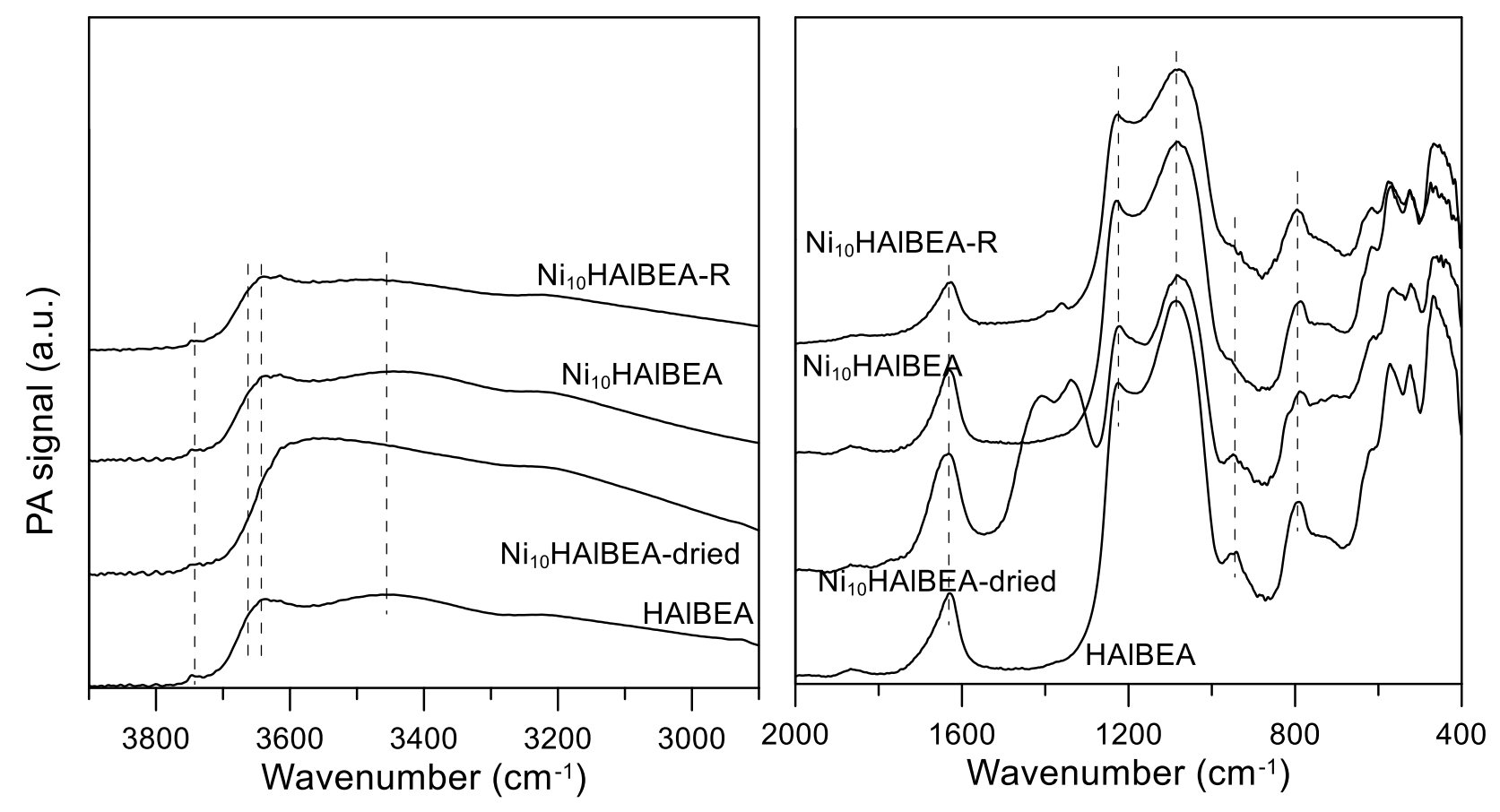

Fig. 4a. 

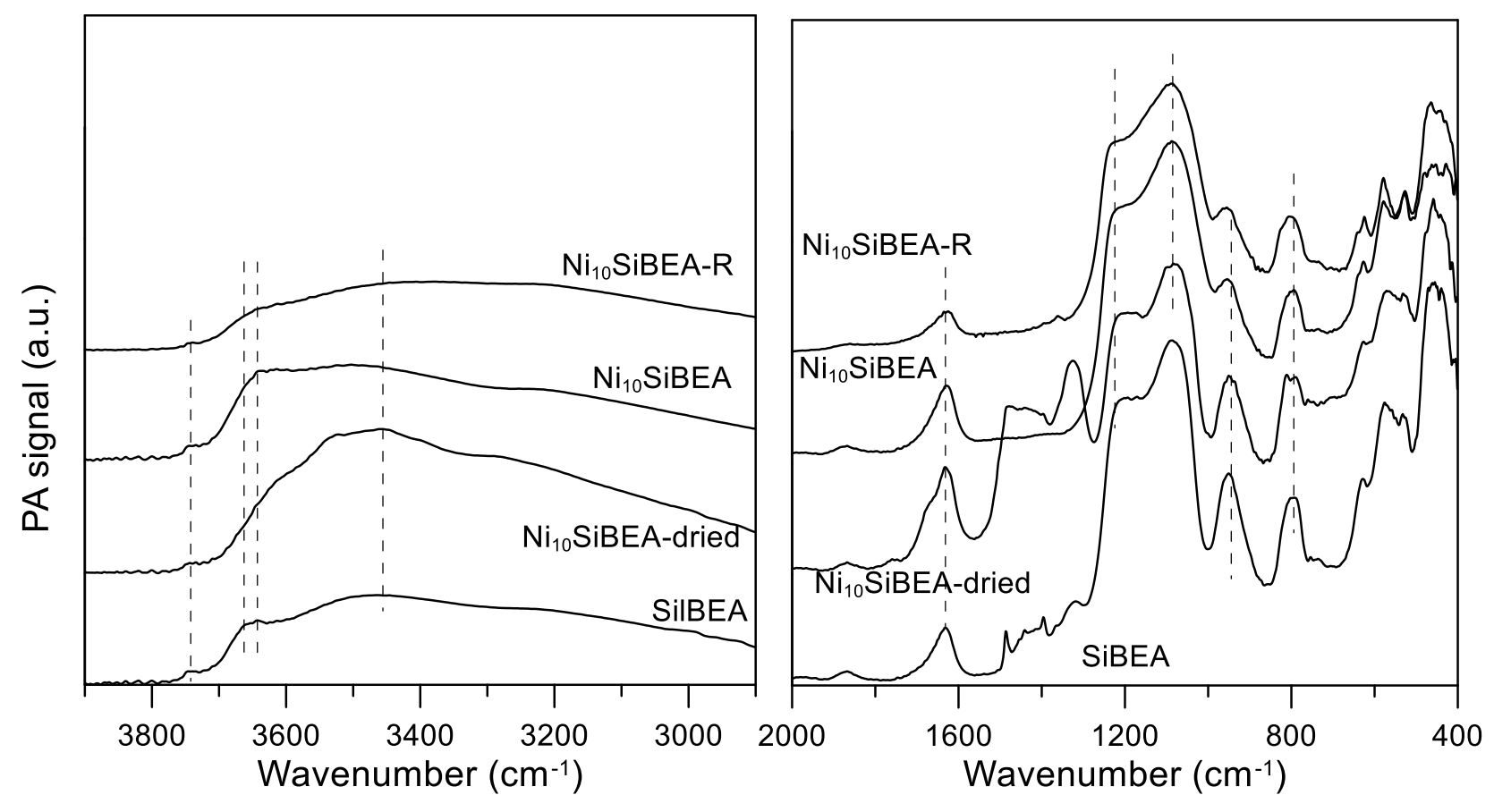

Fig. 4b. 


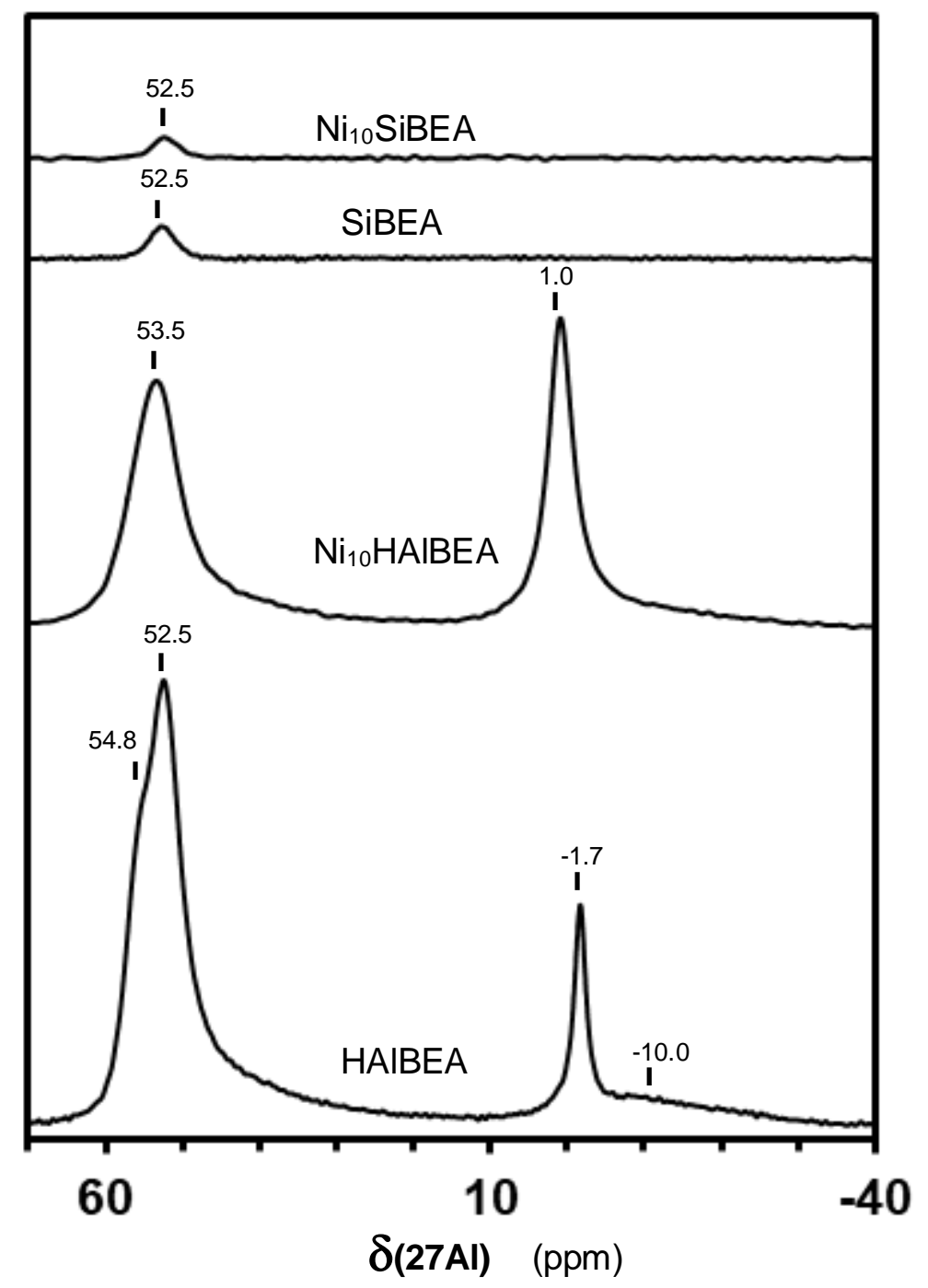

Fig. 5 


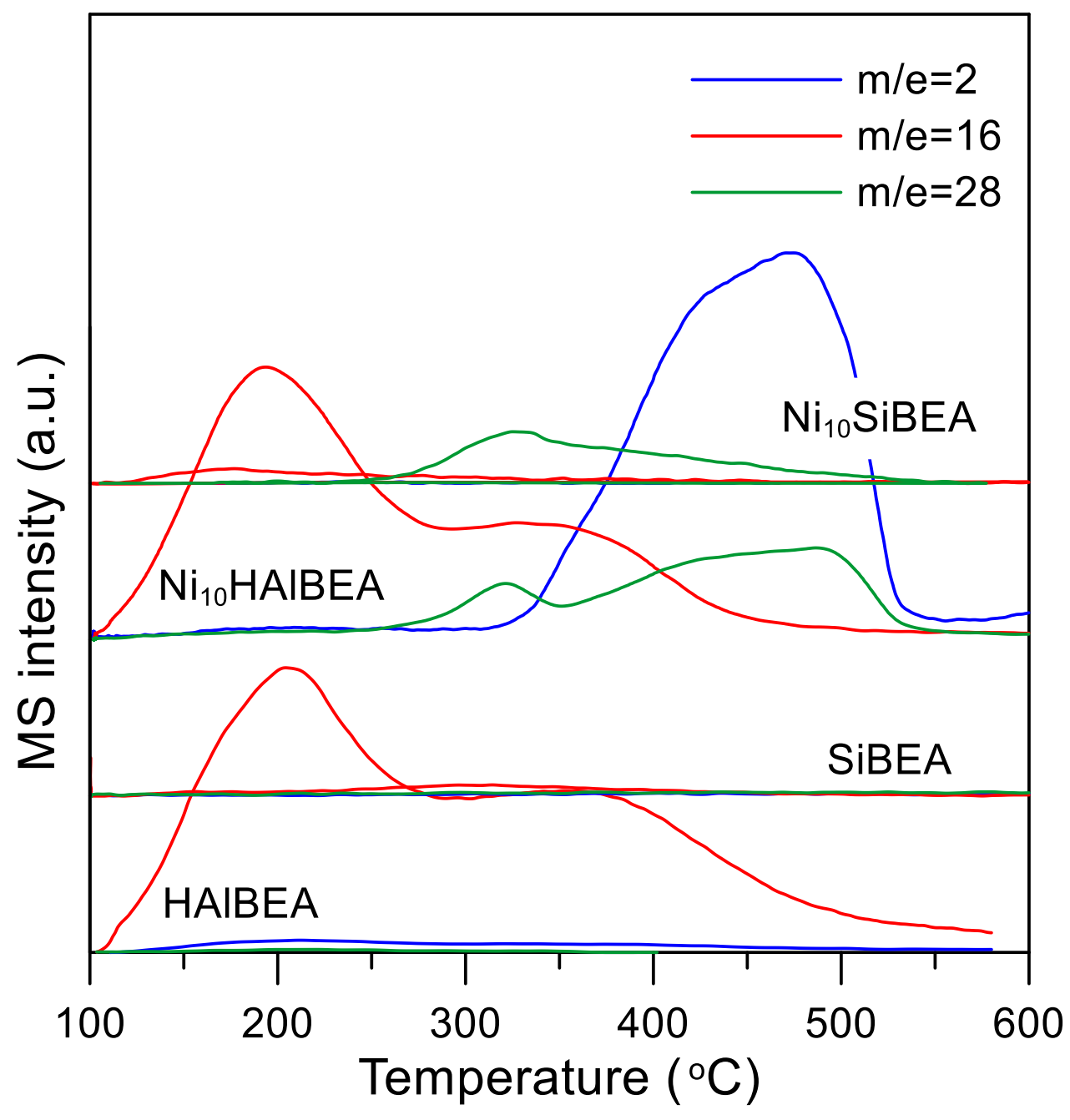

Fig. 6. 


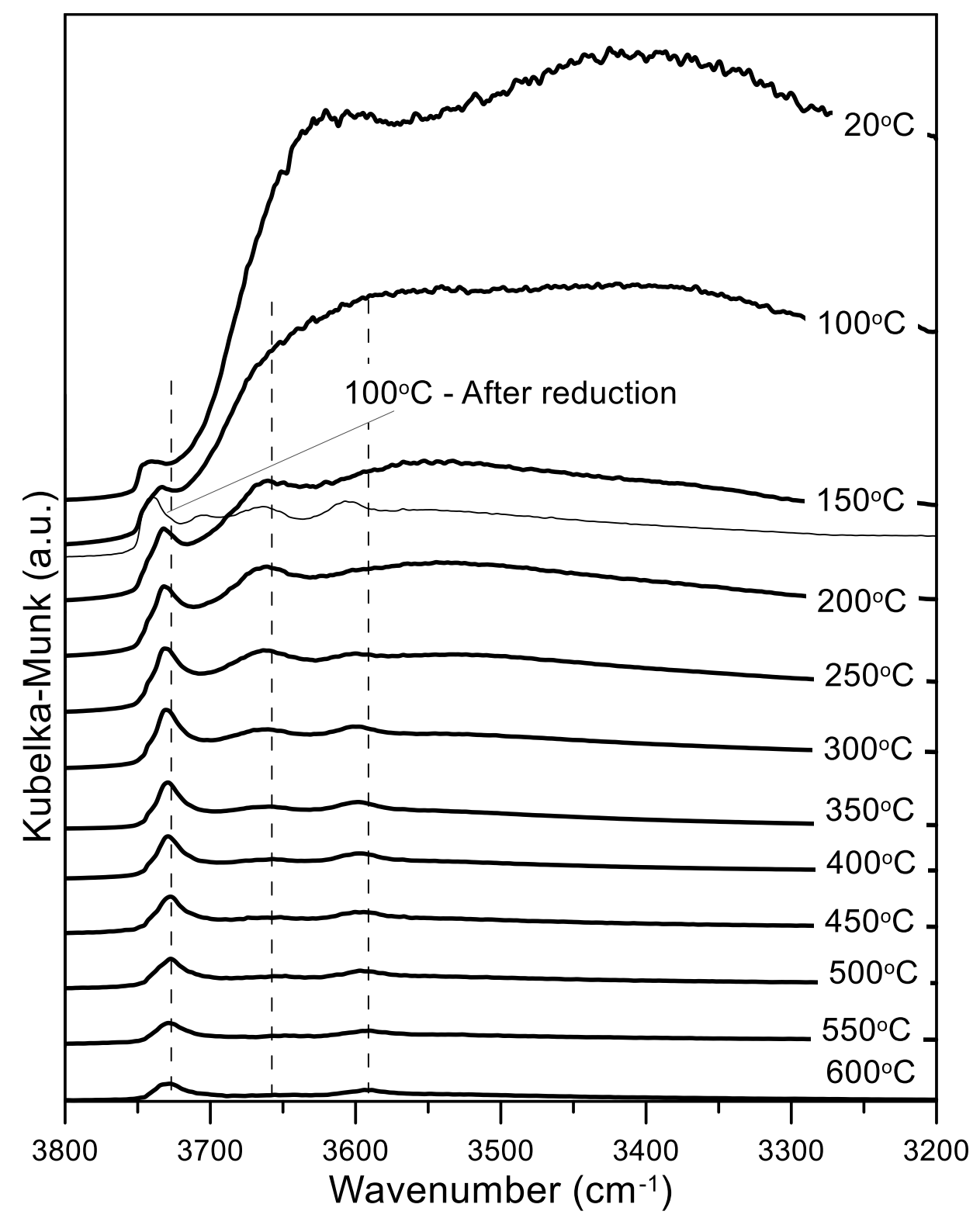

Fig. 7a. 


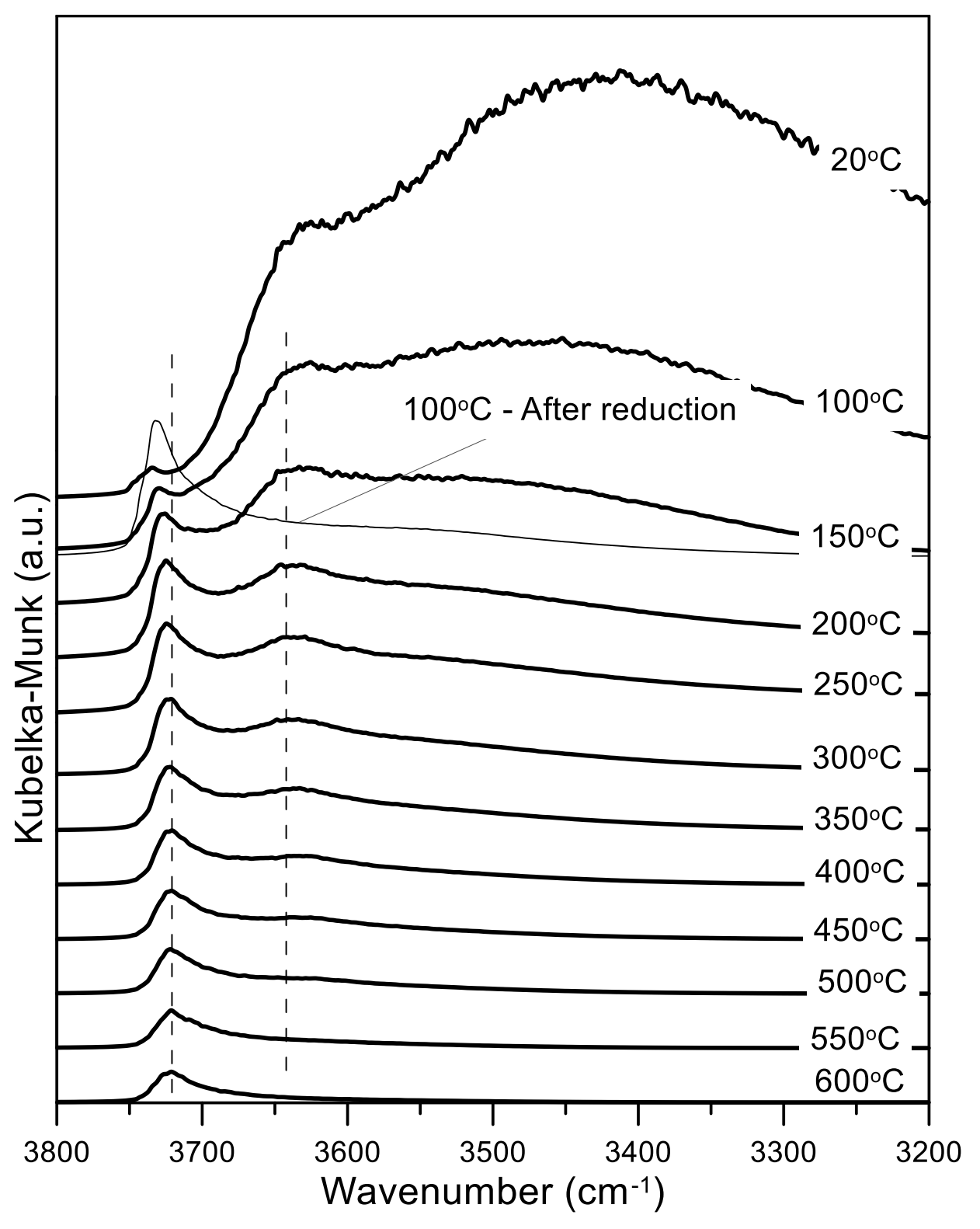

Fig. 7b. 


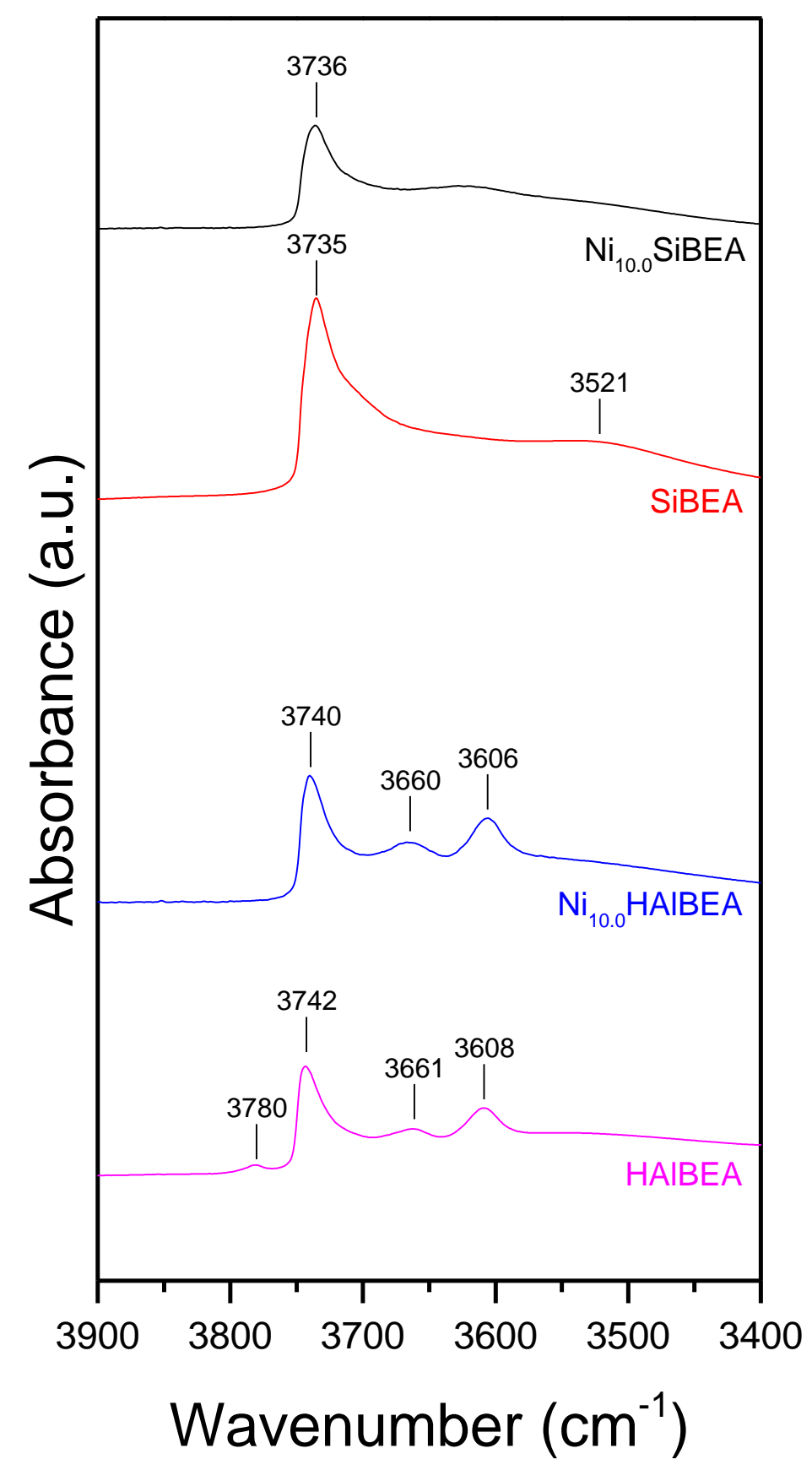

Fig. 8. 


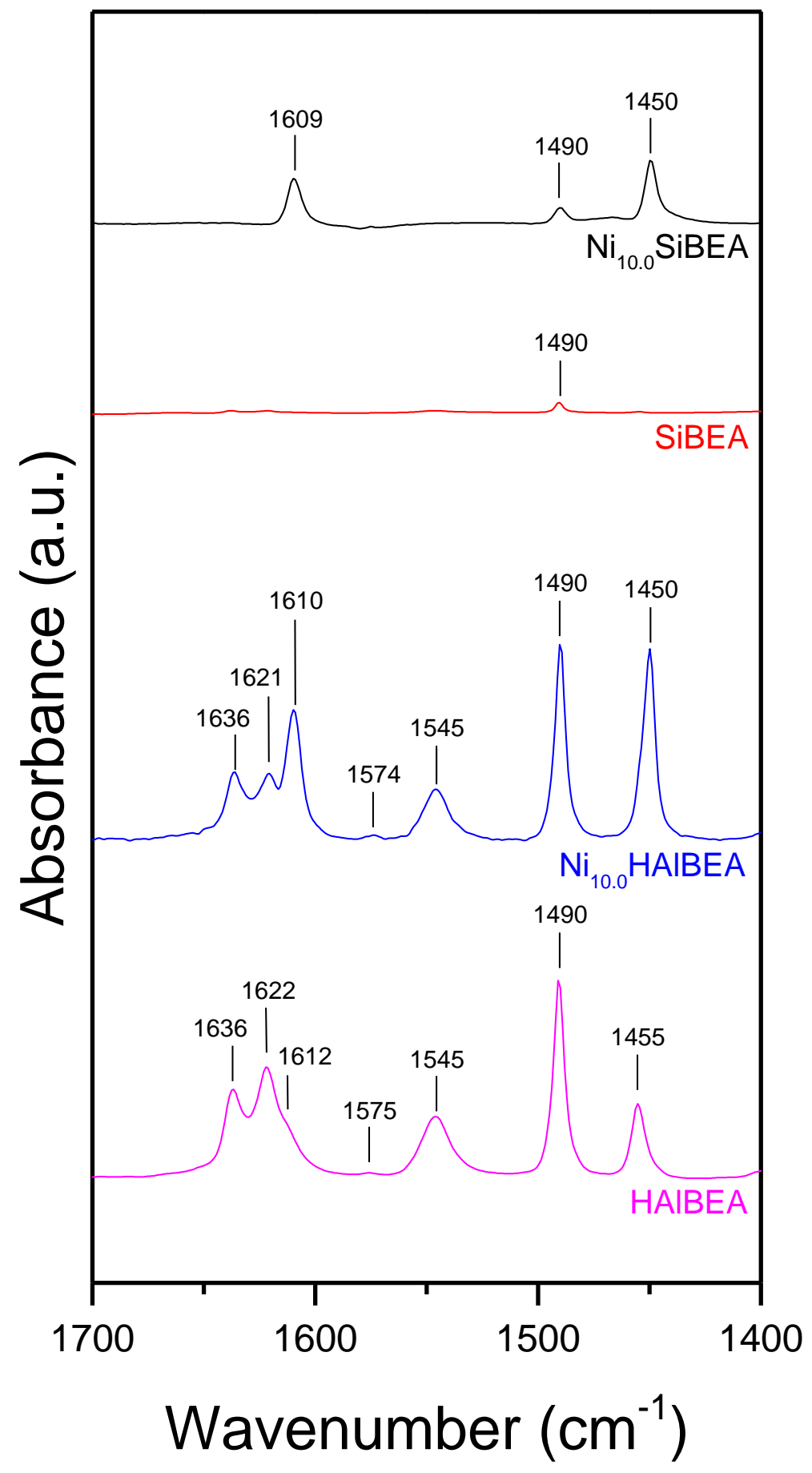

Fig. 9. 


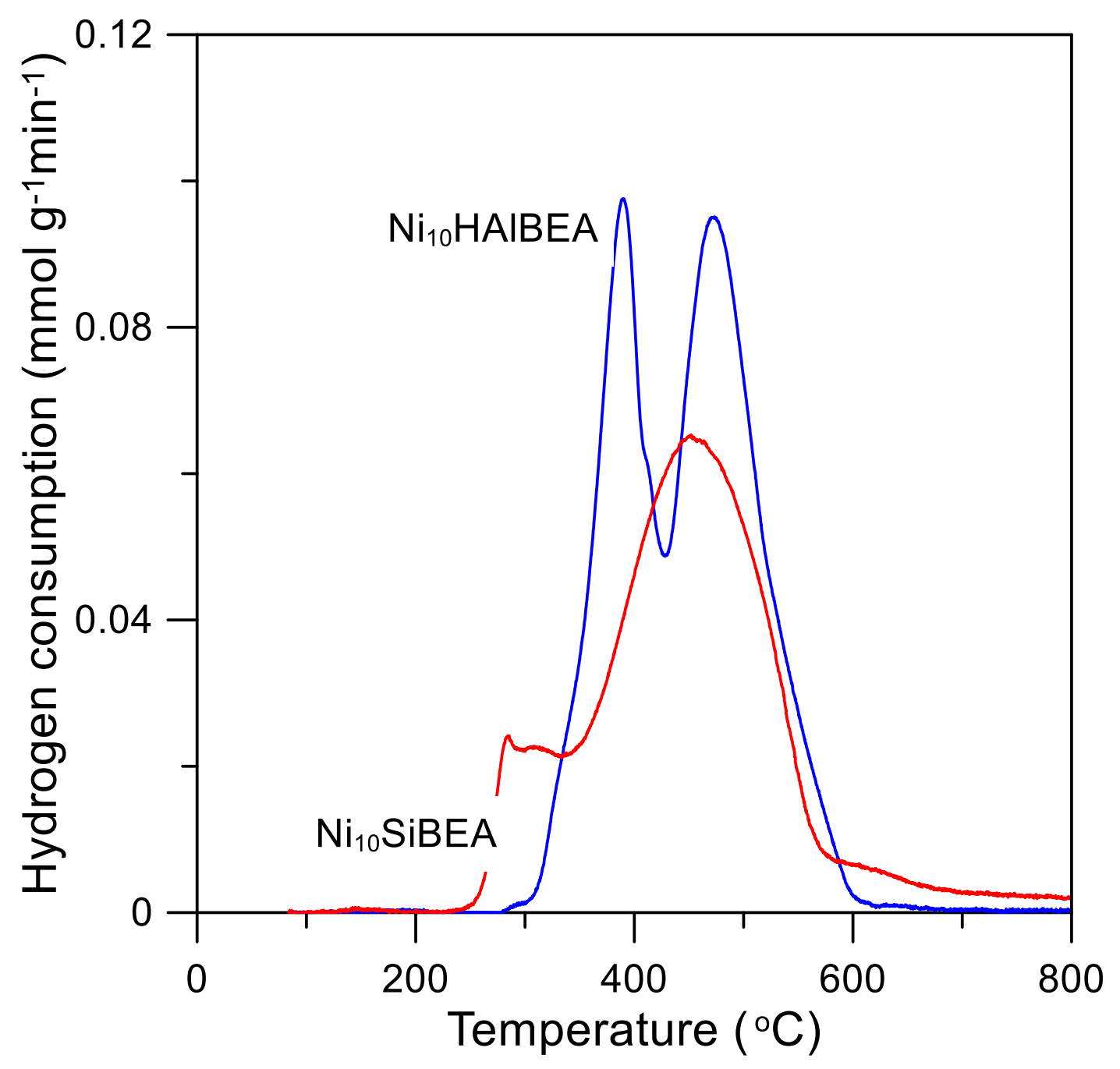

Fig. 10. 


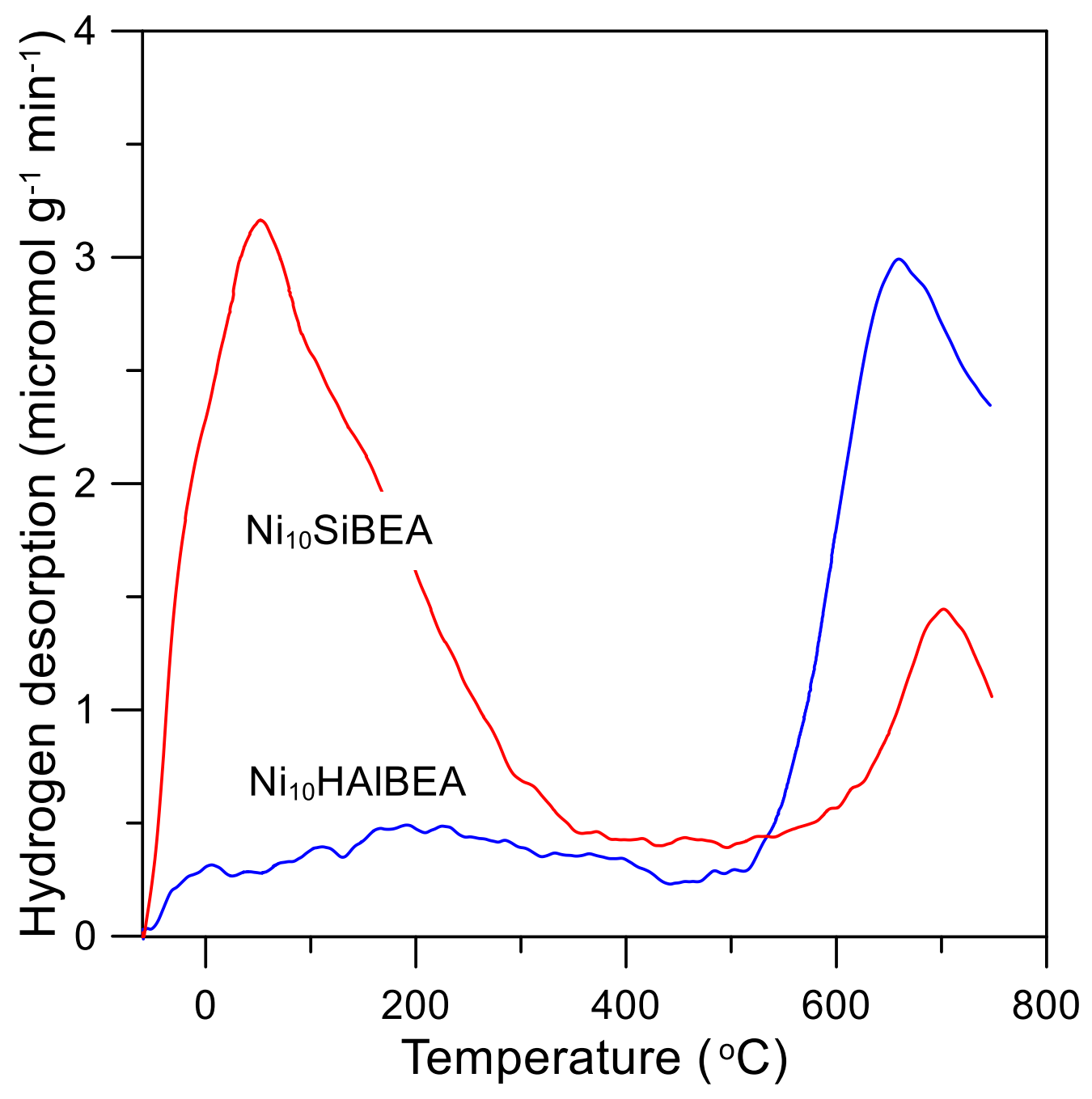

Fig. 11. 


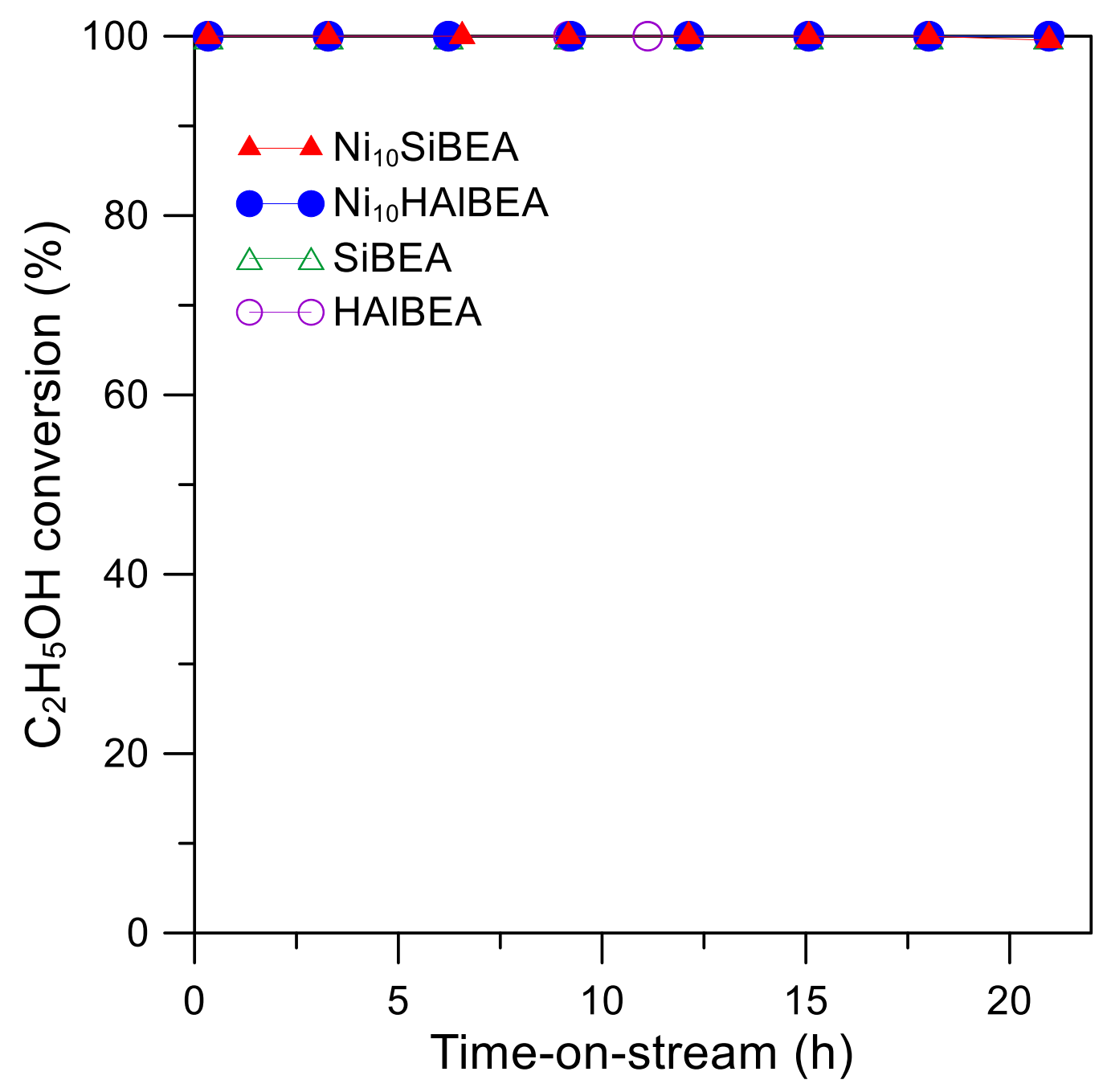

Fig. 12a. 


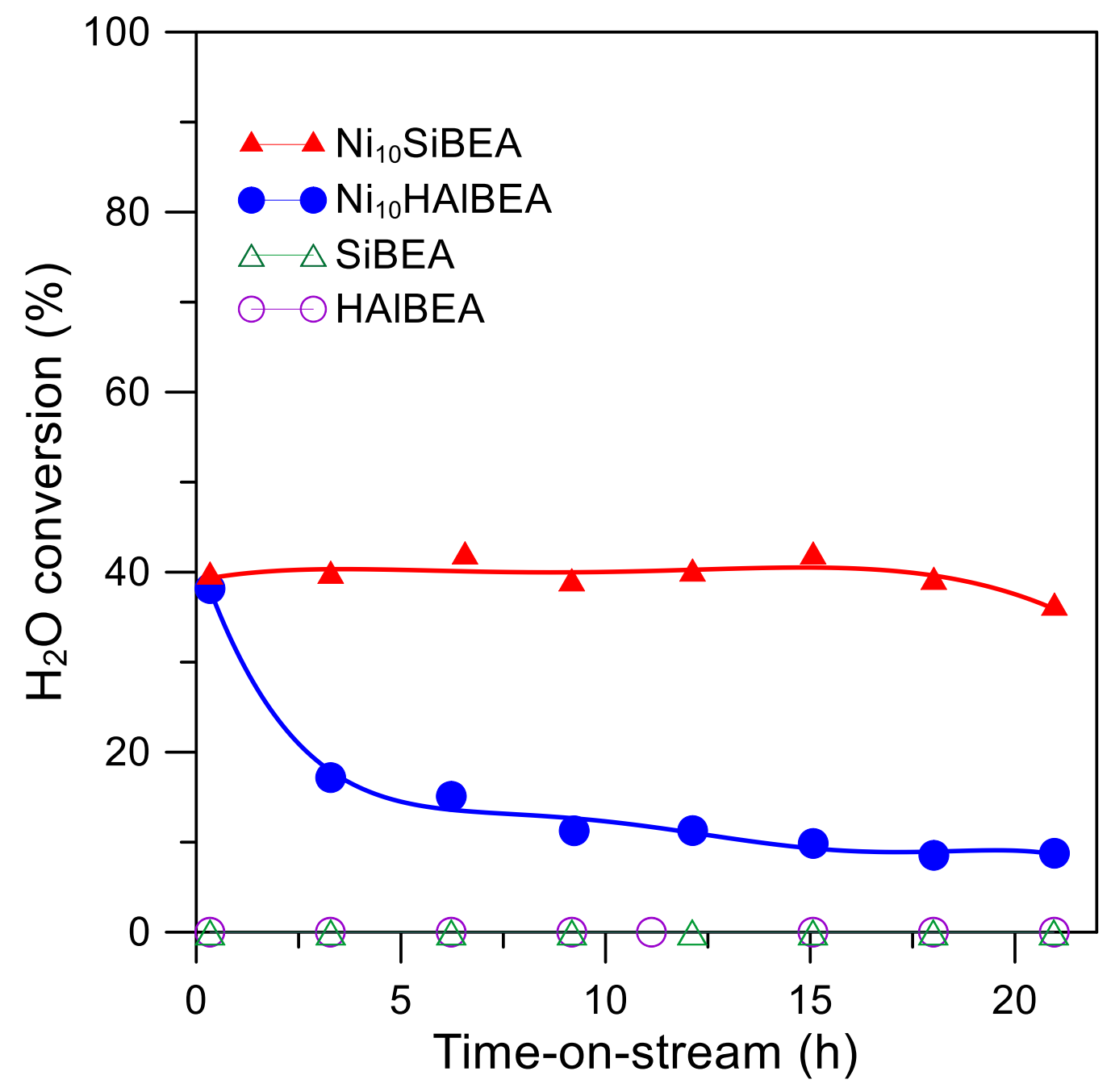

Fig, 12b. 


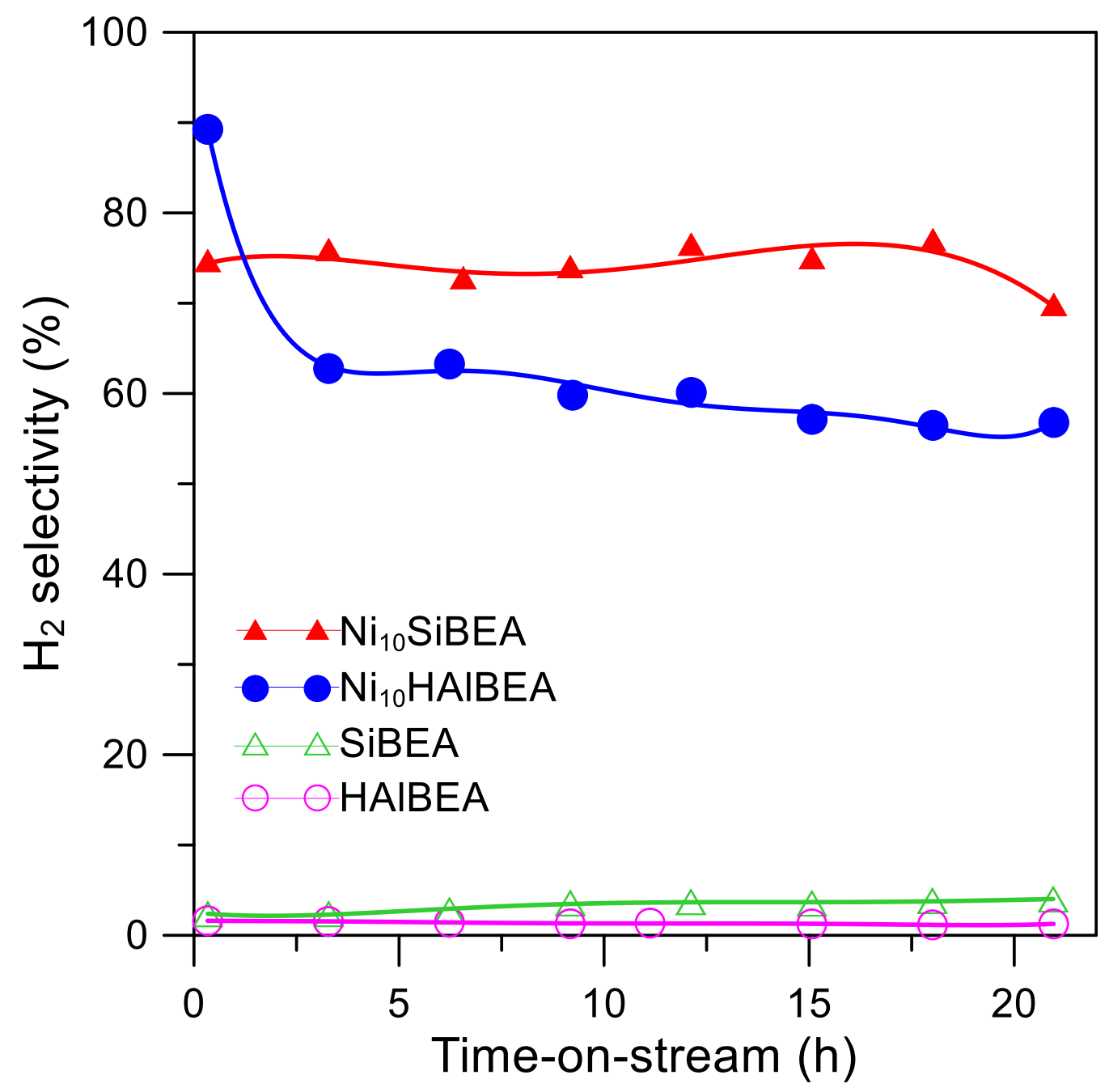

Fig, 12c. 


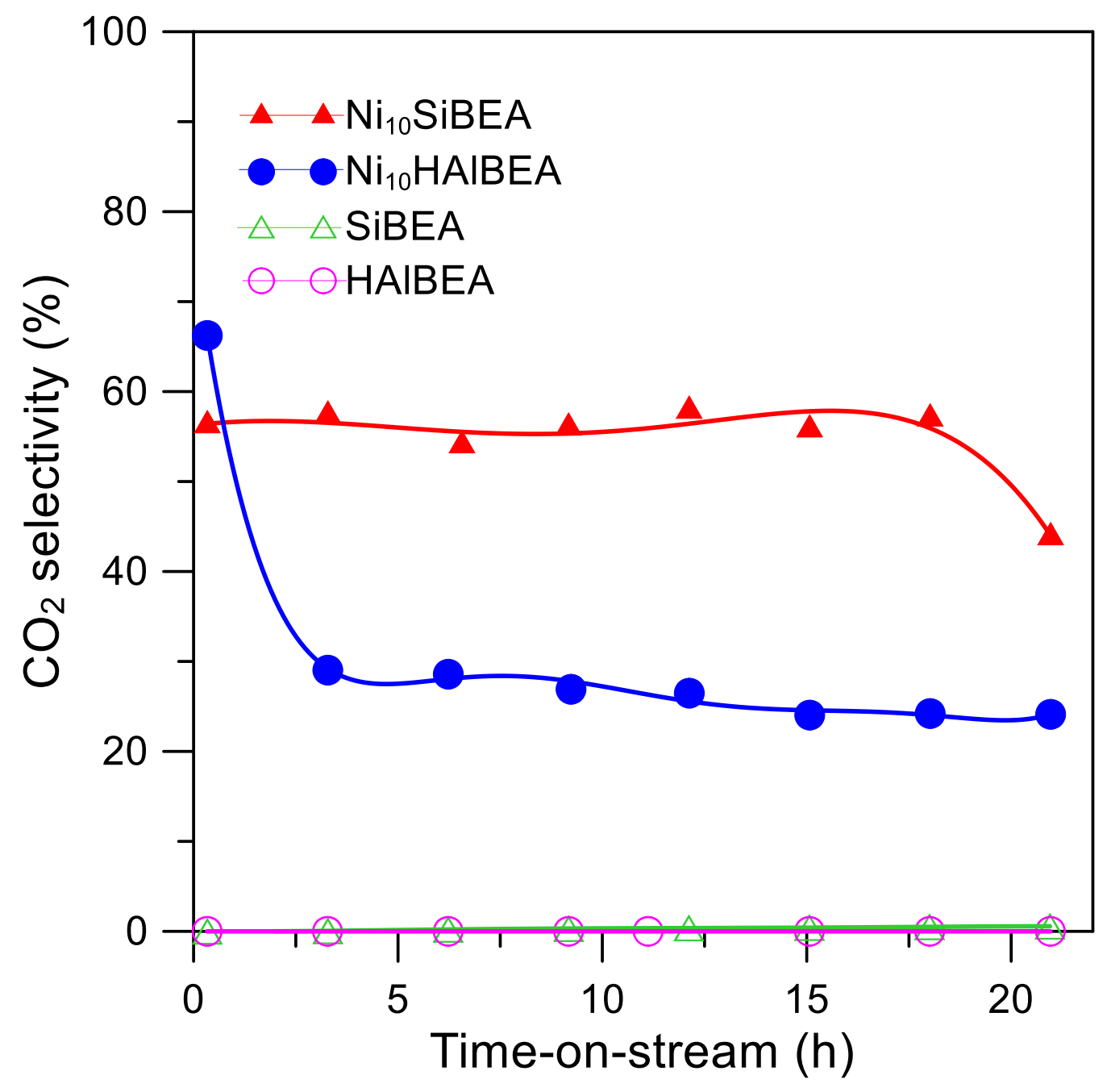

Fig. 12d. 


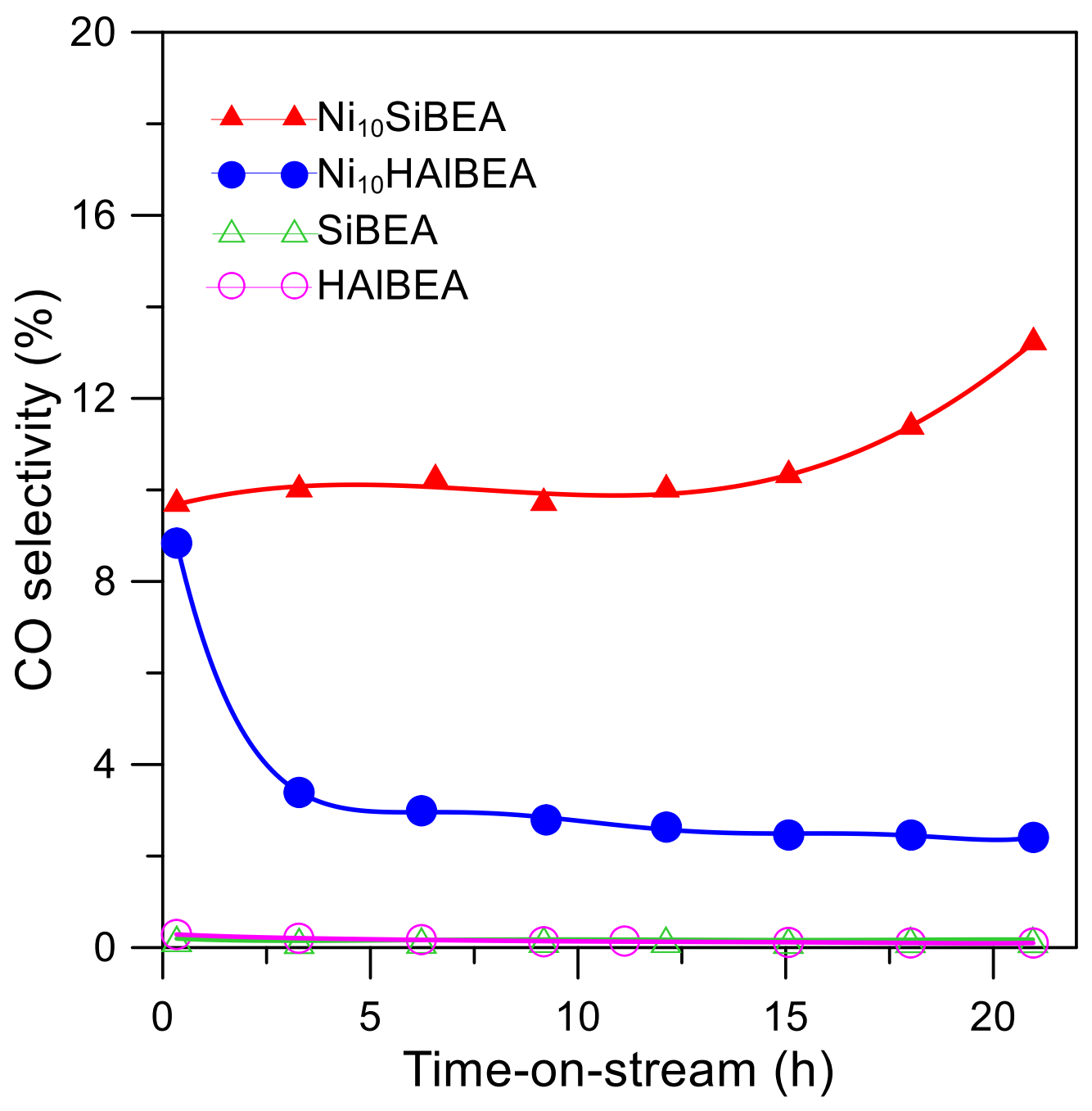

Fig. 12e. 


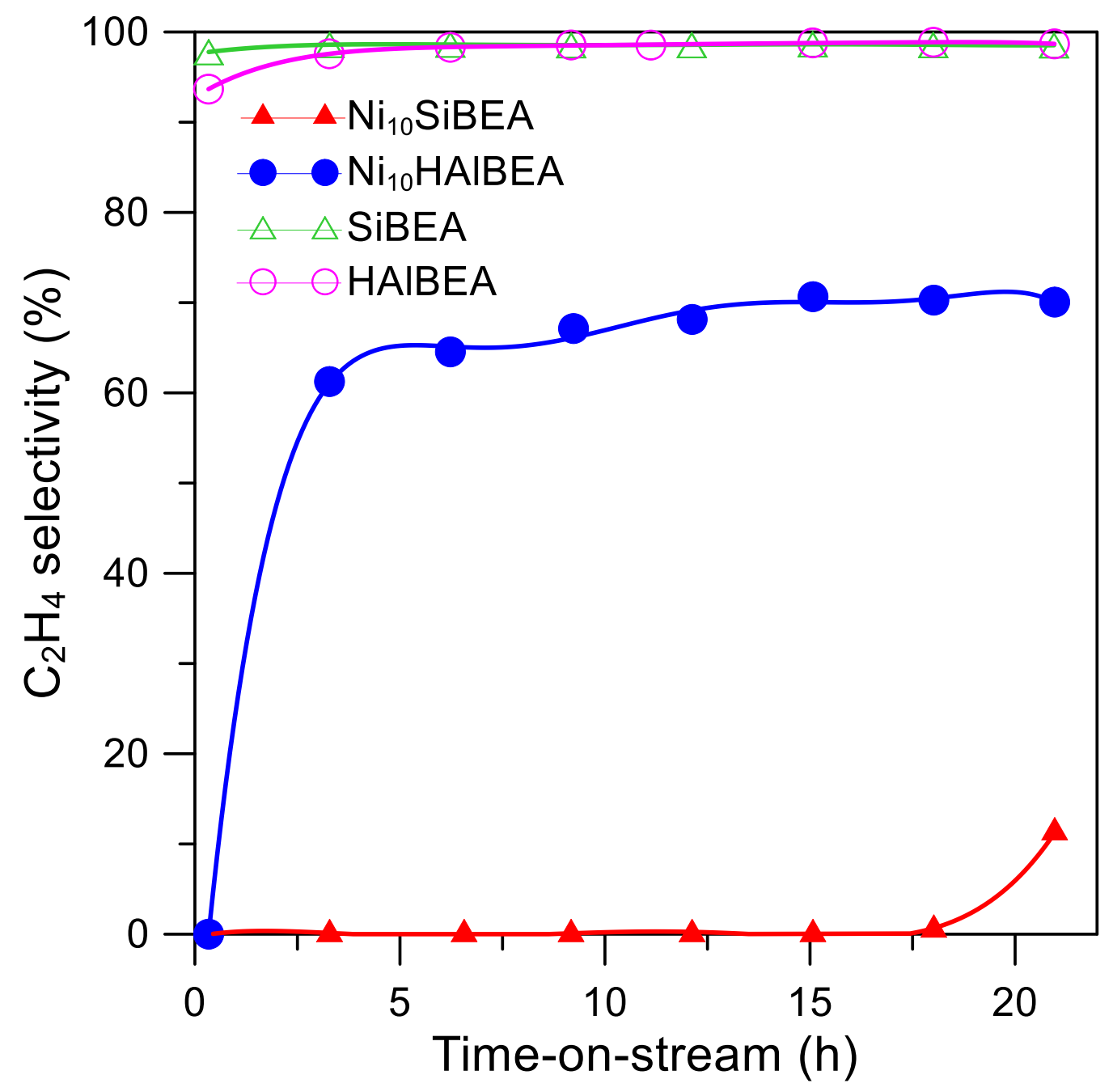

Fig. 12f. 


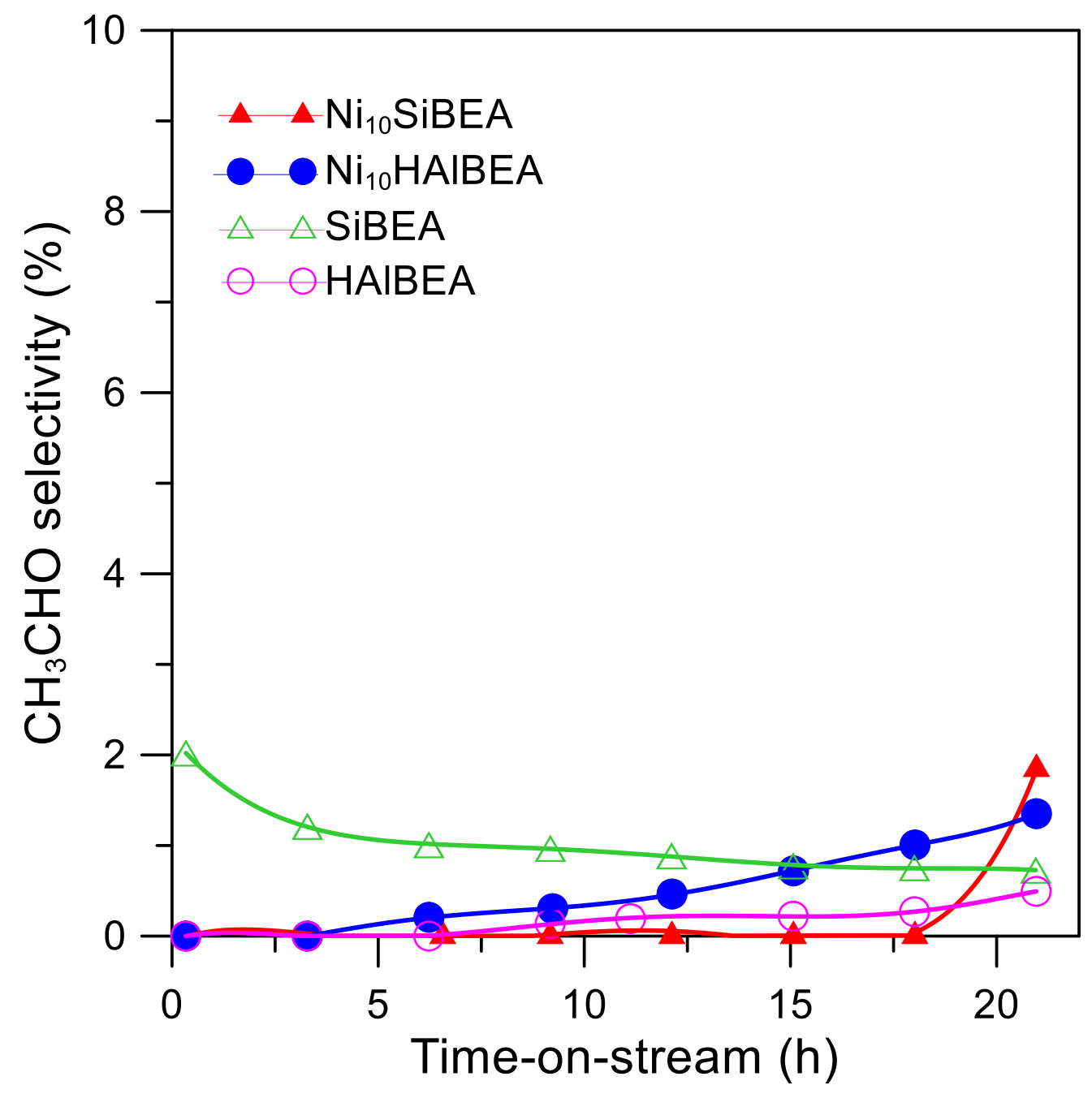

Fig. 12g. 


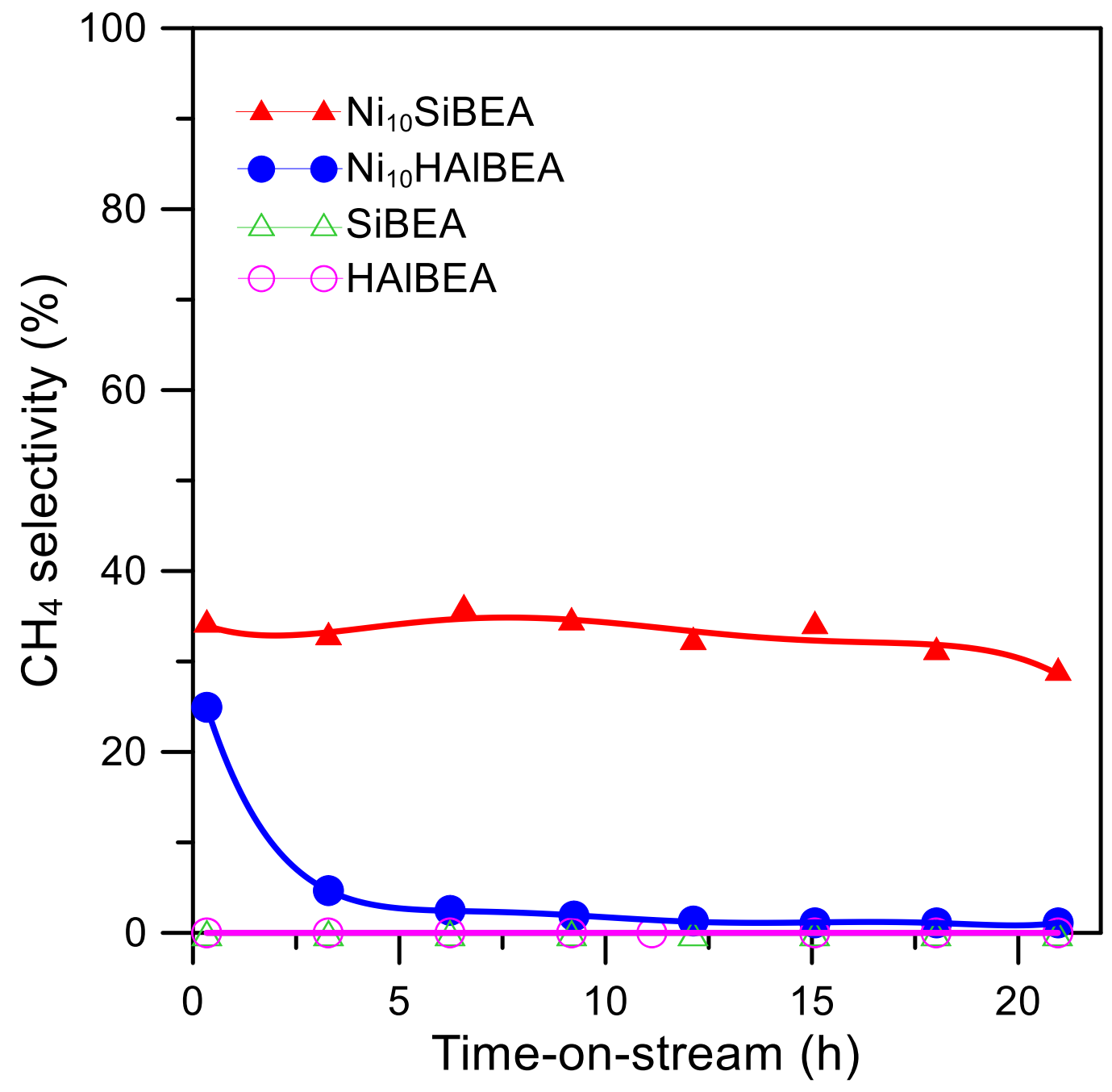

Fig. 12h. 


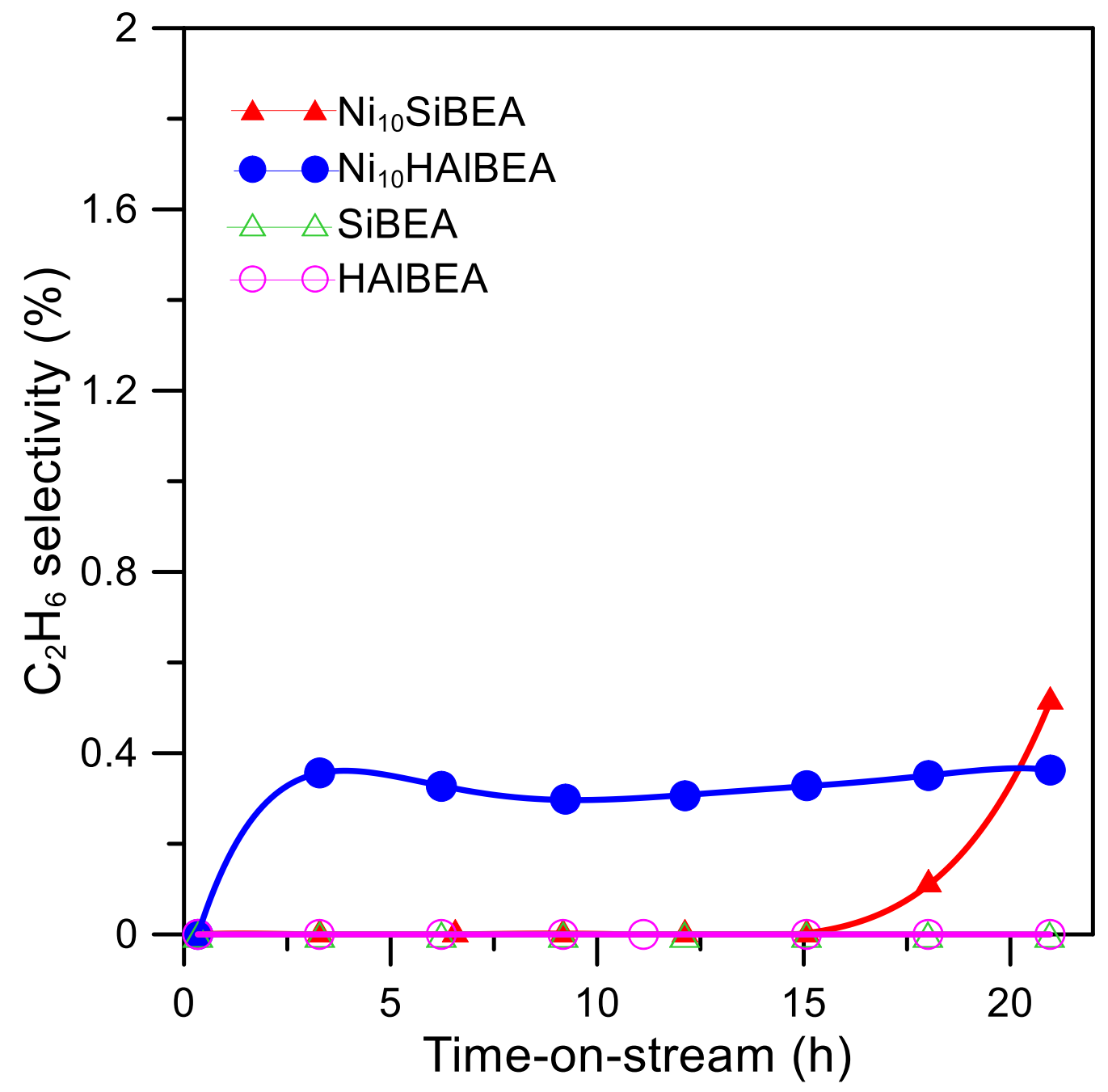

Fig. 12i. 


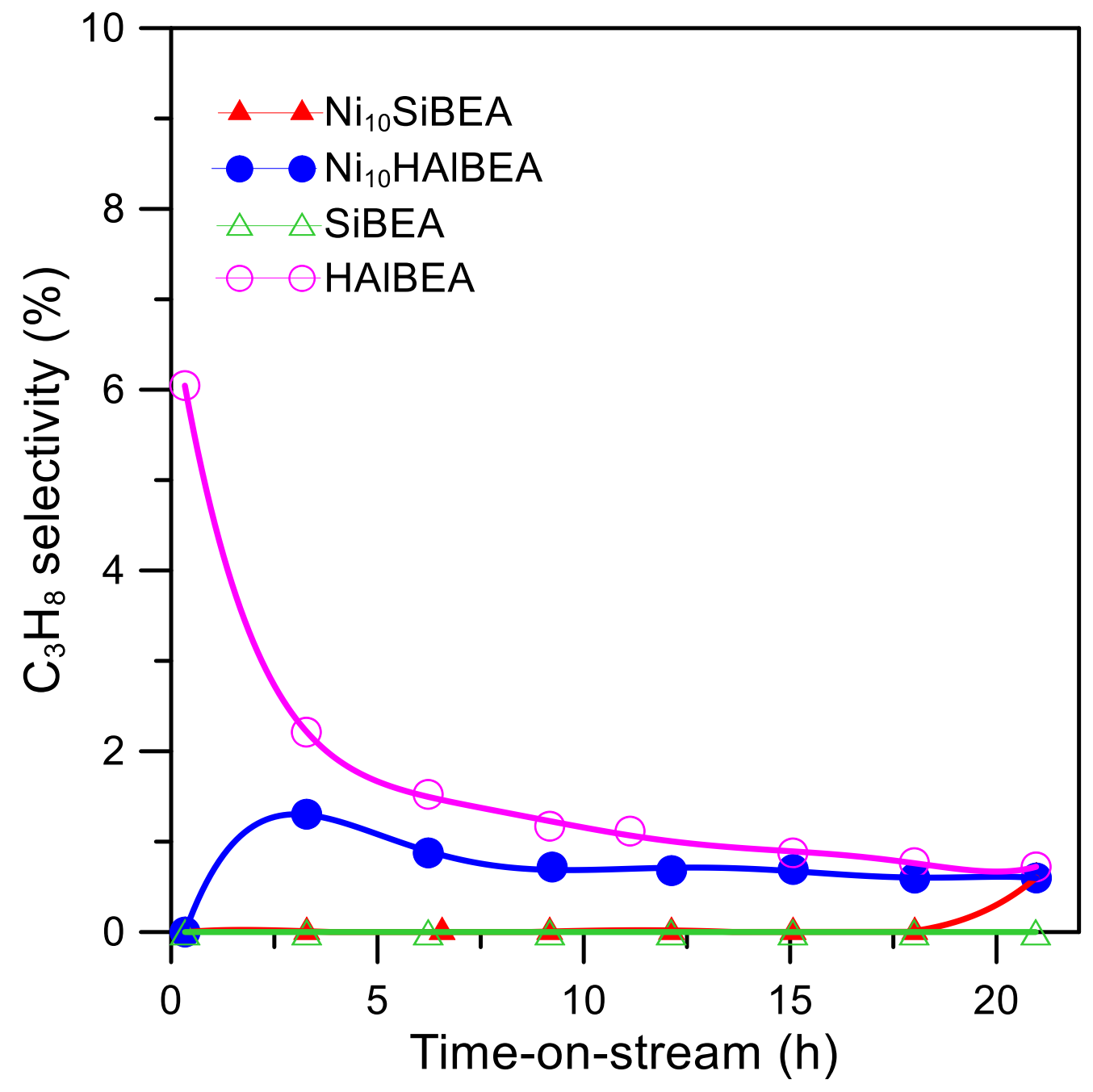

Fig. 12j. 


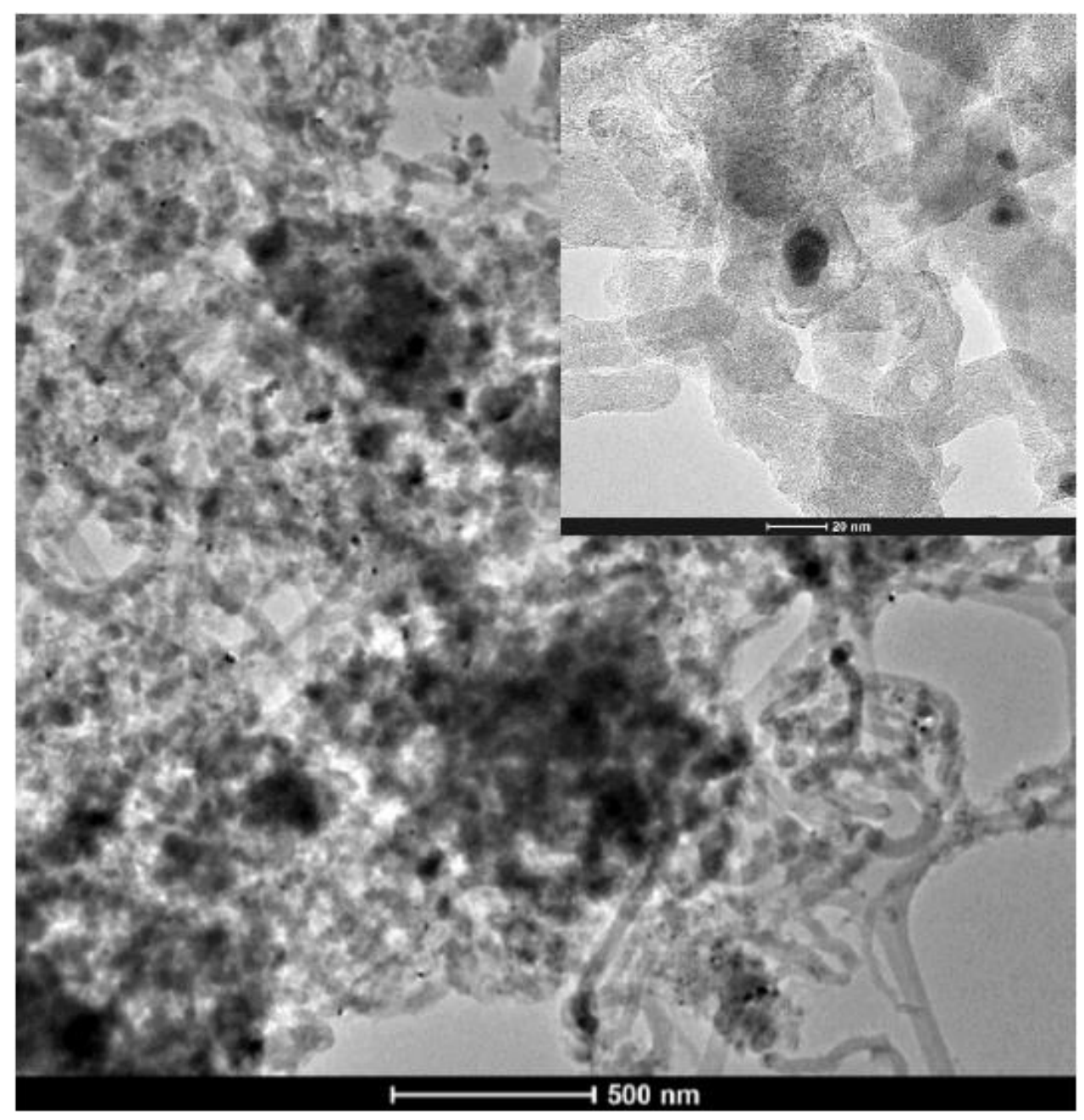

Fig. 13a. 


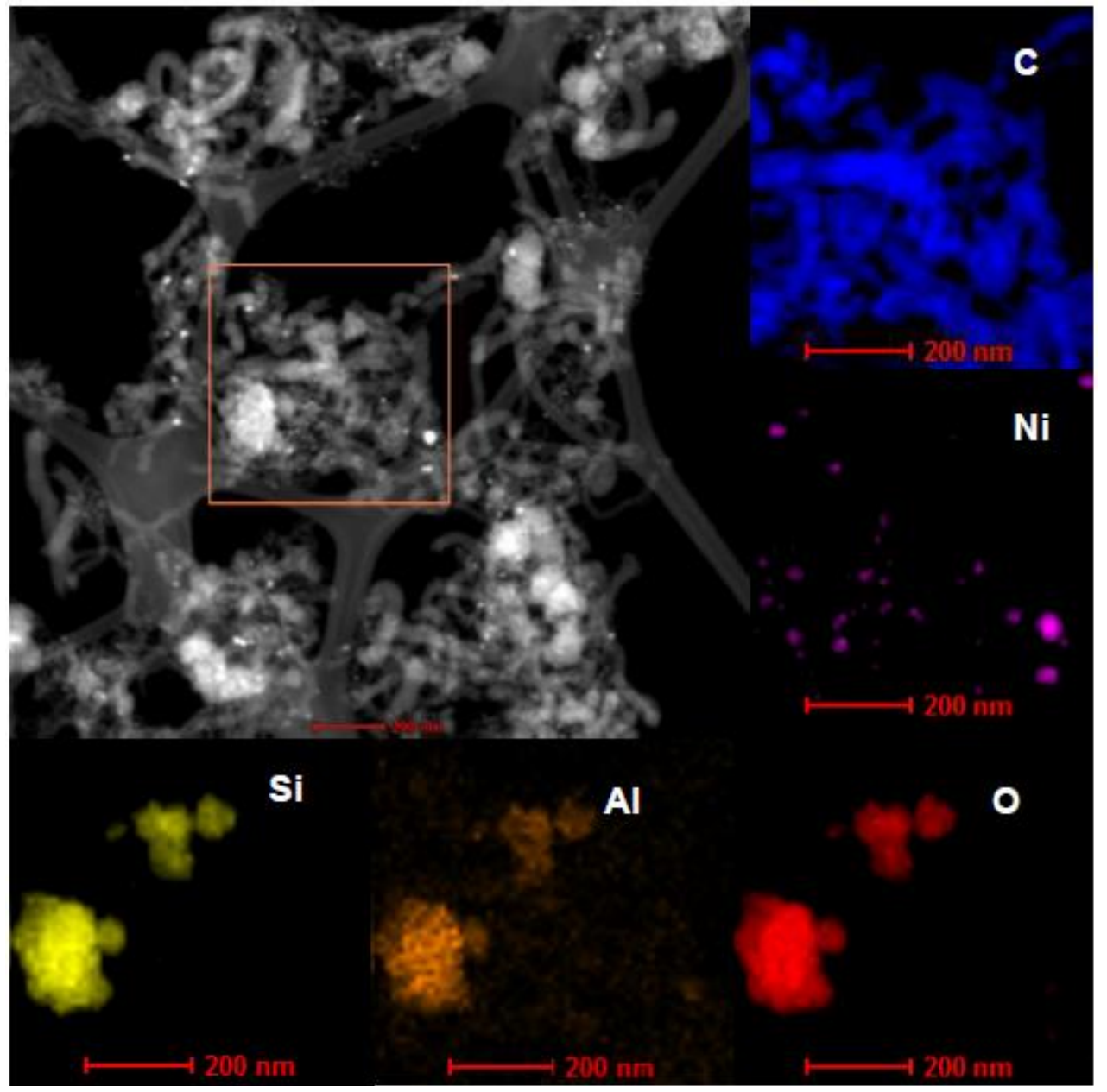

Fig. 13b. 


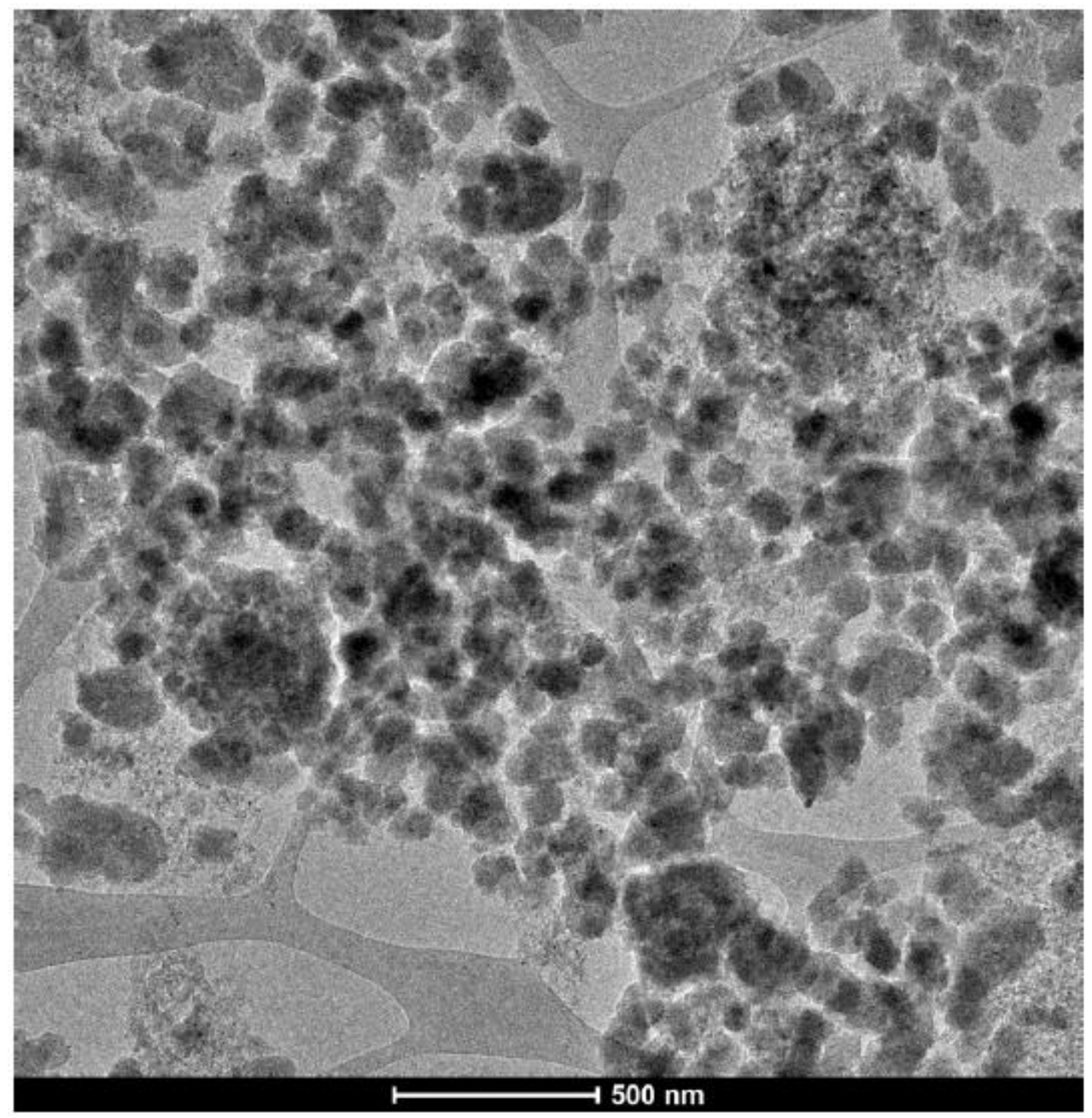

Fig. 13c. 


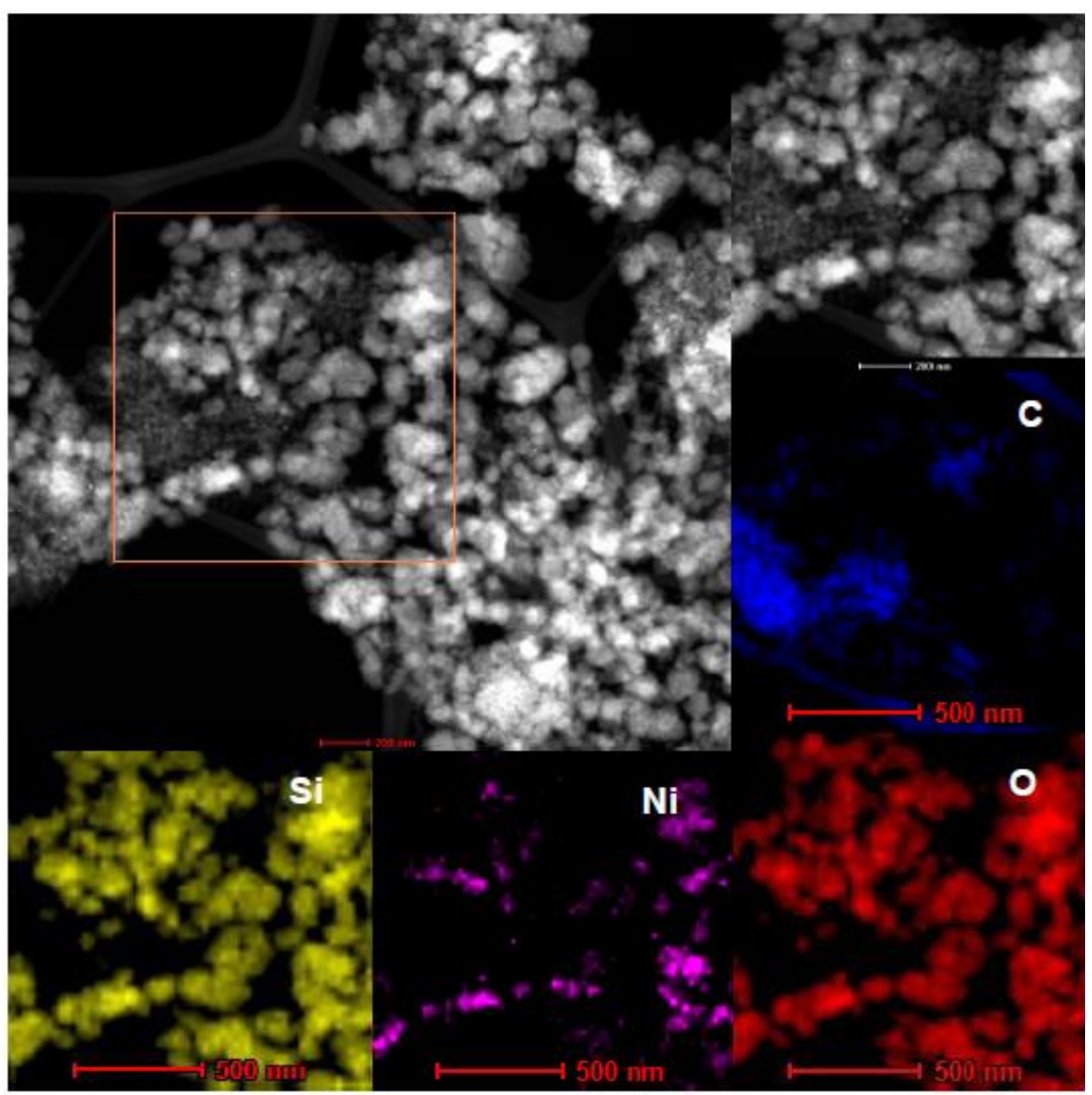

Fig. 13d. 


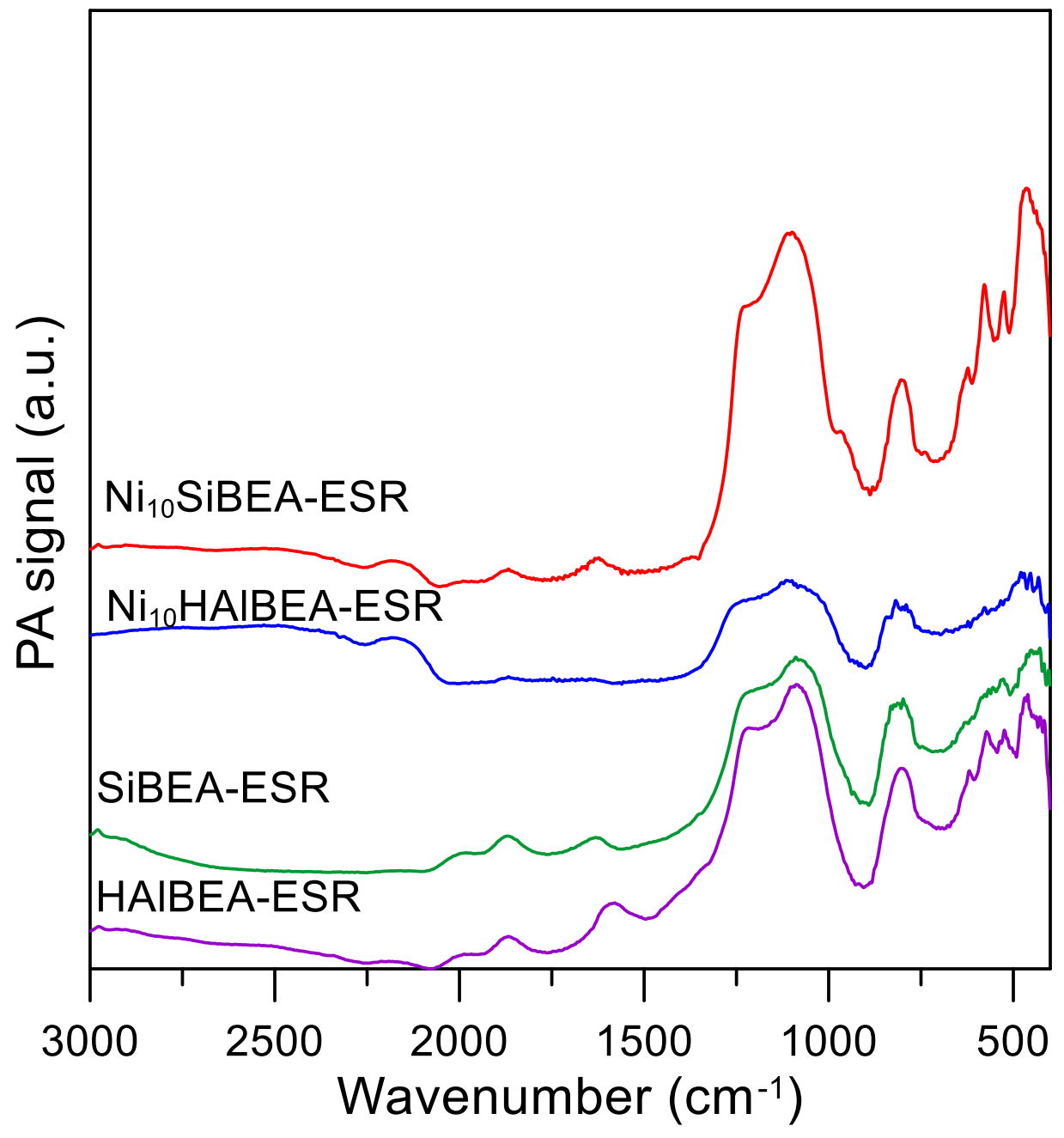

Fig. 14 


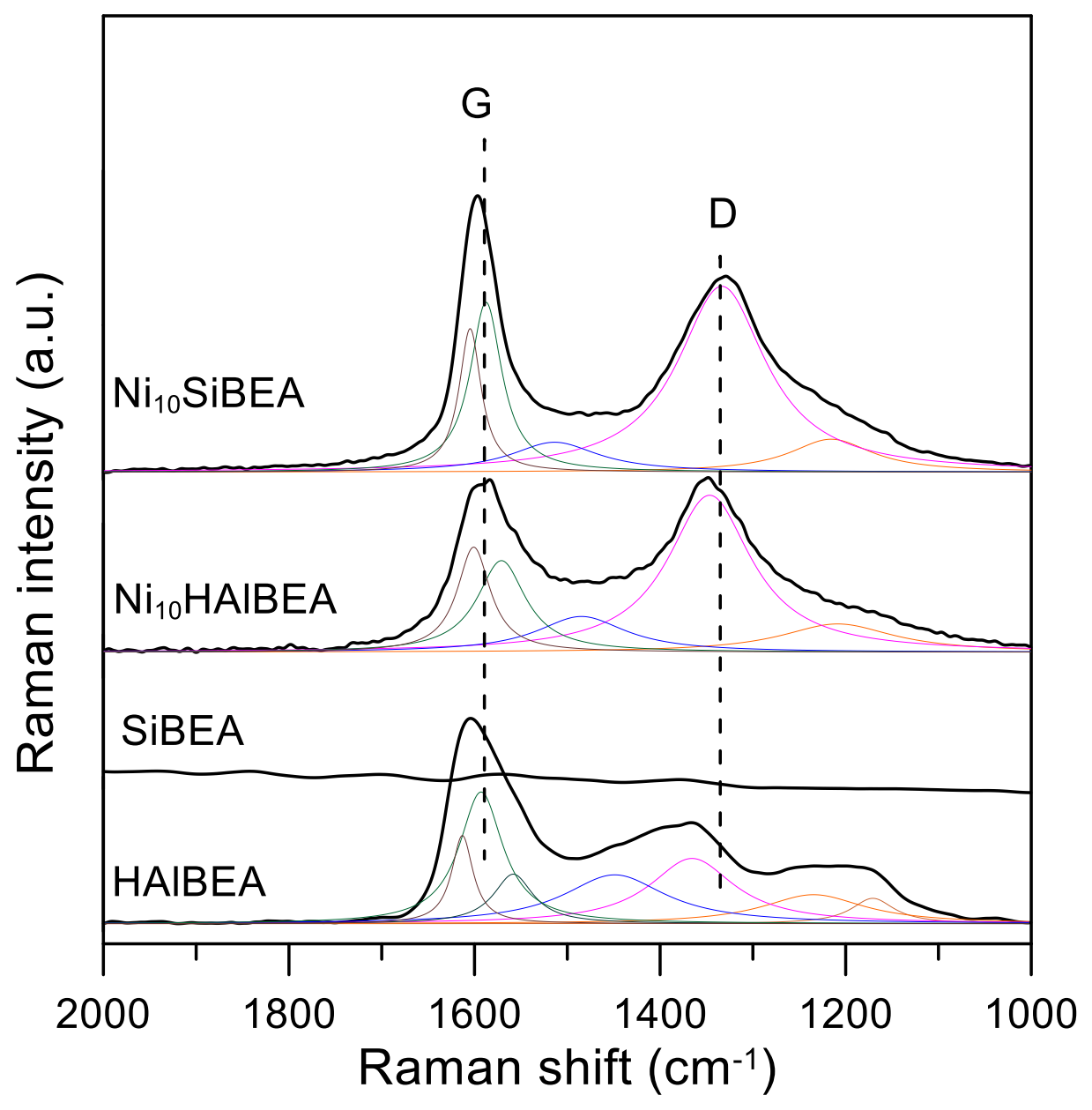

Fig. 15 
Supporting information

Effects of dealumination on the performance of Ni-containing BEA catalysts in bioethanol steam reforming

Wojciech Gac ${ }^{1, *}$, Magdalena Greluk ${ }^{1}$, Grzegorz Słowik ${ }^{1}$, Yannick Millot ${ }^{2}$, Laetitia Valentin ${ }^{2}$, Stanislaw Dzwigaj ${ }^{2 *}$

${ }^{1}$ Department of Chemical Technology, Faculty of Chemistry, Maria Curie-Sklodowska

University, 3 M. Curie-Sklodowska Sq., 20-031 Lublin, Poland

${ }^{2}$ Laboratoire de Réactivité de Surface, Sorbonne Université-CNRS, UMR 7197, F-75005, Paris, France 


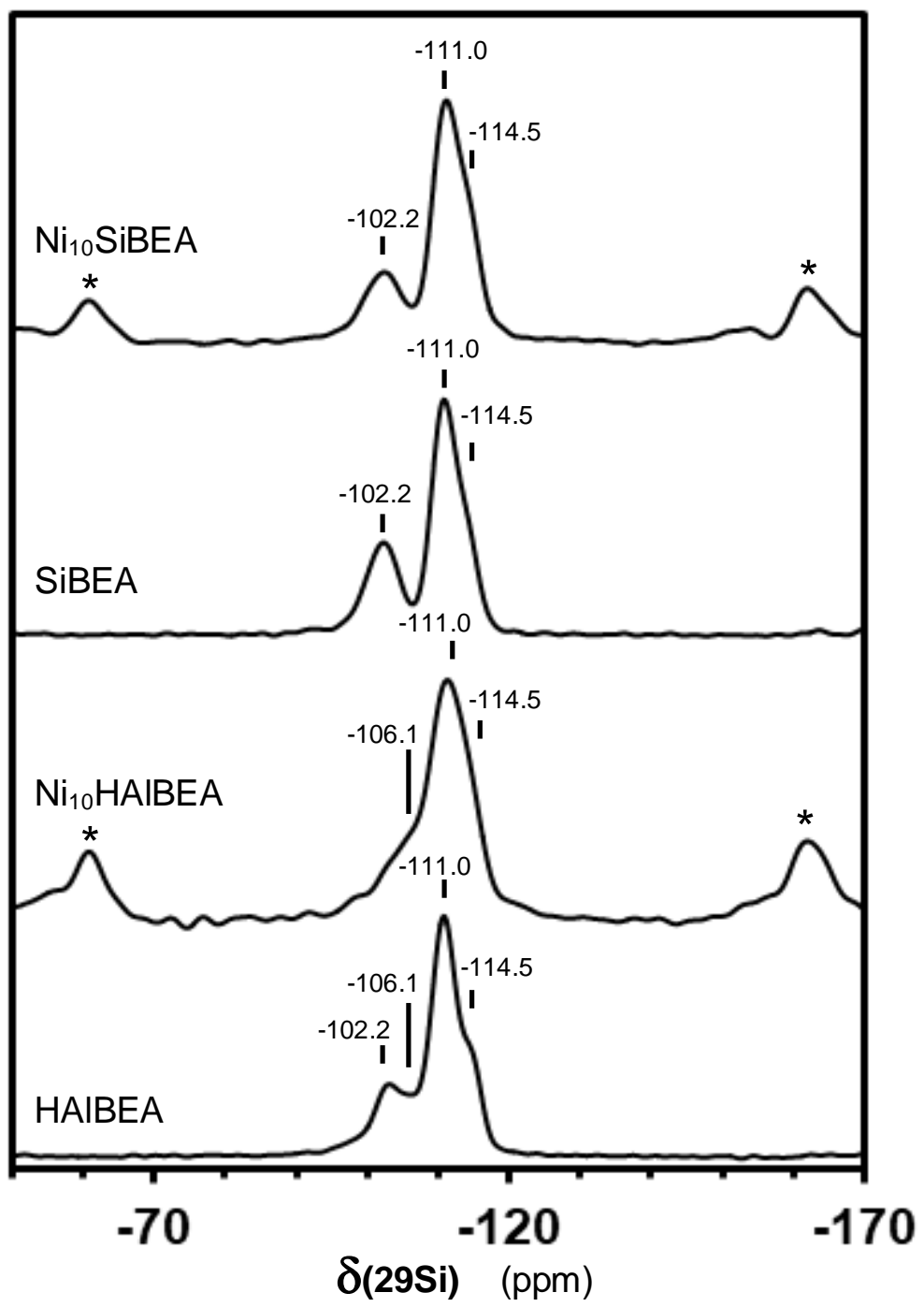

Figure S1: ${ }^{29} \mathrm{Si}$ MAS NMR spectra of HAIBEA, Ni ${ }_{10} \mathrm{HAIBEA}$, SiBEA and $\mathrm{Ni}_{10} \mathrm{SiBEA}$ (* spinning sidebands) 


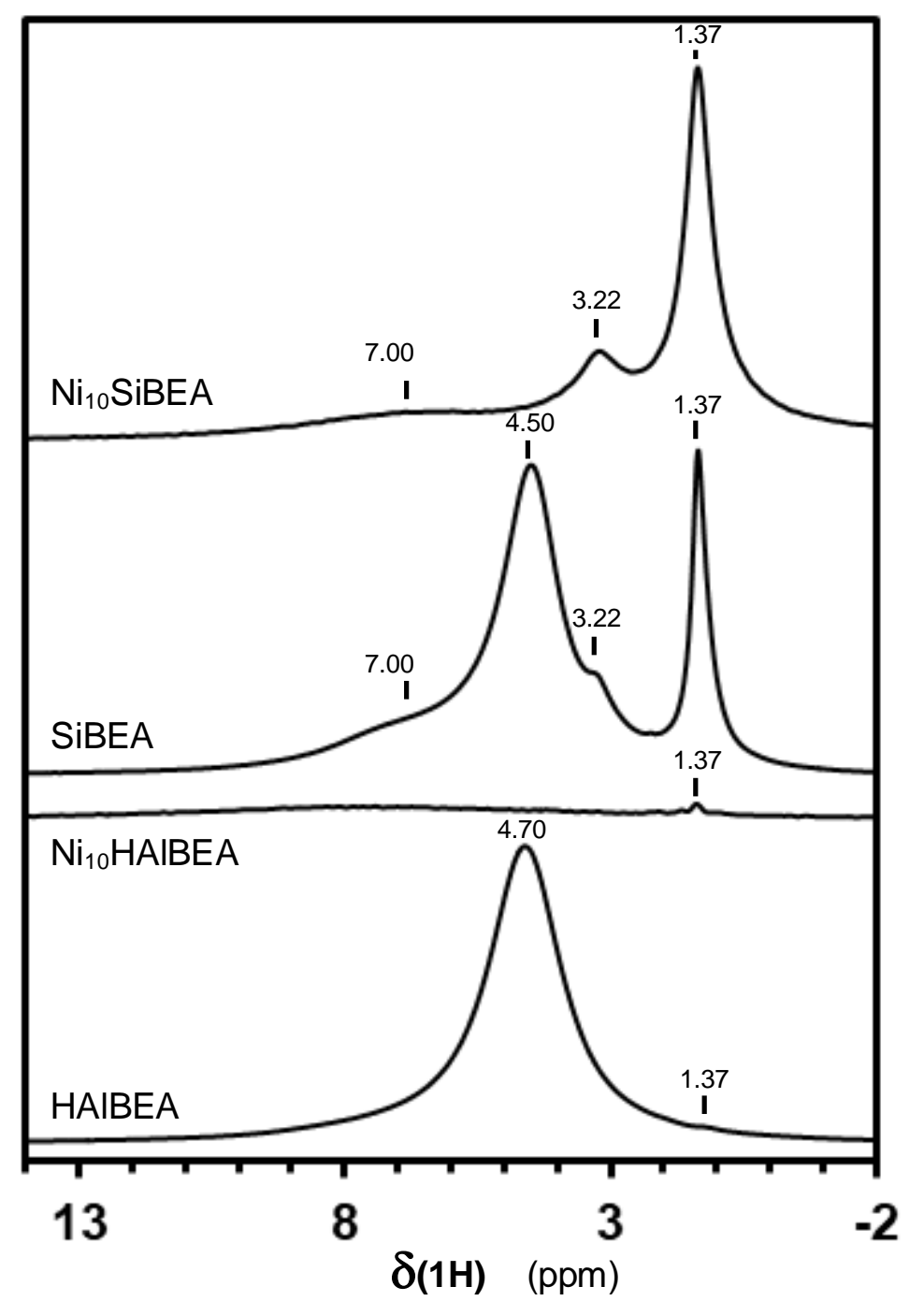

Figure S2: ${ }^{1} \mathrm{H}$ MAS NMR spectra of HAIBEA, $\mathrm{Ni}_{10} \mathrm{HAIBEA}$, SiBEA and $\mathrm{Ni}_{10} \mathrm{SiBEA}$ 